\title{
مشاركة الطلاب في عروض المسرح الجامعي وعلاقتها بتنمية بعض سمات الشخصية لانيهم
}

أ. أد/ أماني عبد المقصود عبدالوهاب

أستاذ الصحة النفسية والارشاد النفسي ورئيس

قسم العلوم التربوية والنفسية

كلية التربية النوعيـة - جامعـة المنوفية

عبير مهدي سيد أحمد خواجة
أ. أد / صوفيا عباس أحمد

أستاذ الدراما والنقد ورئيس قسم المسرح

بكلية الآداب جامعة الاسكندرية

د. فرج عمر فرج

مدرس الاعلام والدراما والنقد كلية

النربية النوعية جامعة المنوفية

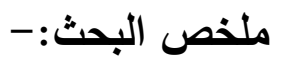

استهدف هذا البحث التعرف علي مدي فعاليـة مشاركة الطـلاب في عروض المسرح

الجامعي وتتمية بعض سمات الثخصية لديهم وتتمنل هذه السمات في ( الثقة بالنفس - الاتزان

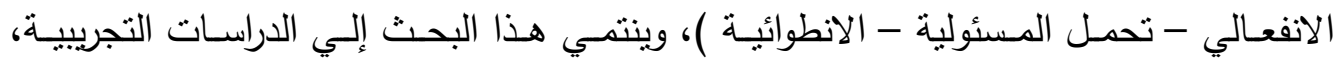
واستخدمت الباحثة عدة أدوات تضمنت: مقياس سمات الثخصية كأداه لجمع البيانات المطلوبـة لإنة وثثلاث مسرحيات هى: مسرحية رقص الغربان ومسرحية يوم التلات الساعة خمسة، ومسرحية

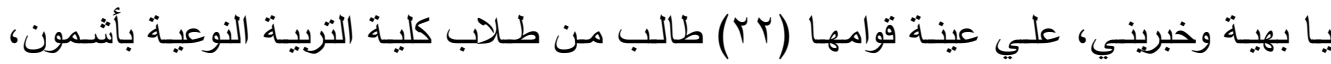
وتوصلت إلى نتائج أهمها: وجود فروق دالة احصائياً بين منوسط درجات الطلاب في القياس

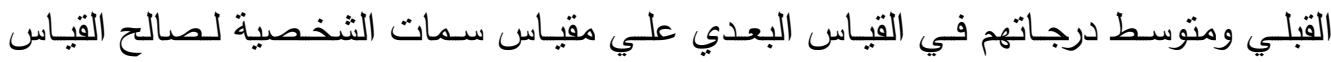

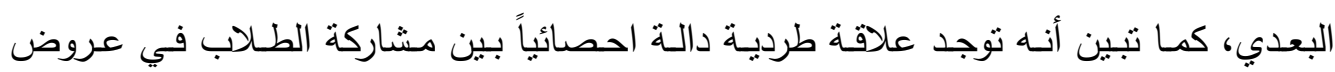

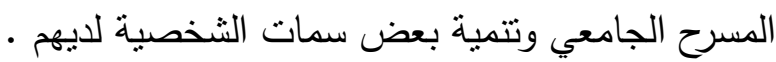




\section{Abstract:}

This study aimed to identify the effectiveness of student participation in University Theatre and the development of personality traits they have these attributes in(self-confidence-emotionalsobrietyresponsibility-introversion), thisresearch elong to the experimental studies, within the framework of this study the researcher used pain The pilot approach used in that measure personality traits as a tool to collect the required data The dance of the crows and the play of the day of the five-day petals, and a play, Bahia and tell me, the researcher has applied to a sample (22) students of college students of Faculty of Specific Education inAshmoun, and reached the results of the most important: There are statistically significant differences between the average grades of students at And the average score in the post-measurement on the scale of personality traits for the benefit of post-measurement, it turns out that there is a direct correlation function between student participation in University Theatre and the development of personality traits they have. 
يعتبر المسرح مـرآة صـادقة تعكس واقـع المجتهـع، ولـه دور كبيـر في تكوين شخصية

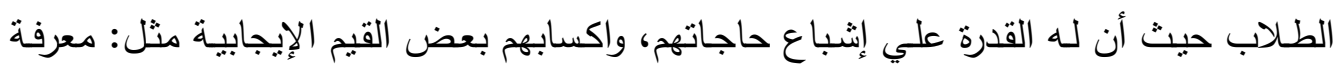

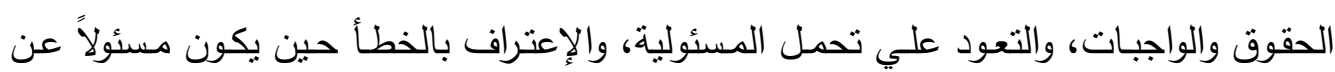

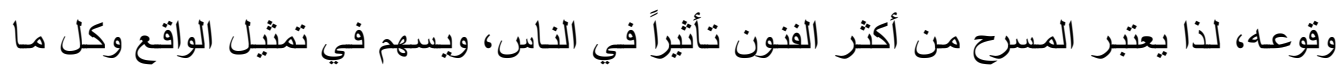
يحدث فيه، حيث يجسد بعض القضايا والمشكلات التي يعاني منها المجتهع، ويقدم أيضاً الحلول المناسبة لها، ويعمل علي زيادة الوعي لدي الطلاب لما يقدمه من أمور ترتبط بحياتهم اليومية ( عايدة علام، . . r، . (1). ويـزود المسرح الجـامعي الطـلاب بالقدر المناسـب مـن المعلومـات والثقافـات والخبـرات، وينمي لديهم الإحساس بمشكلات المجتمع، ويكسبهم القدرة علي التعبير الصحيح، وله القدرة علي تفجير كل الطاقات المخزونـة داخل الطالب، حيث يعمل علي إكتشاف الموهوبين وينمي الموهبة لديهم، ويساعدهم علي التخلص من بعض العيوب كاللجلجة والثأثأة والإنطواء، ويمكن علاج ذللك عن طريق مواجهة الجمهور وعن طريق تقمص دور في مسرحية وعن طريق تقديم

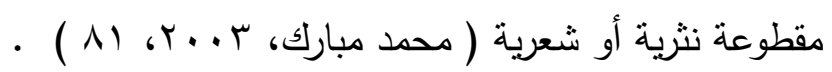

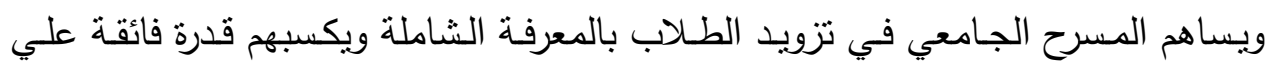
التحليل والفهم للحياة حتي يستطيع مواجتها وحل مشكلاتها، ومن ثم فهو ينمي لدي الطلاب الجرأة والقدرة للتحدث أمام الجمهور والناس. فالمسرح الجامعي يكسب الطلاب التقة بالنفس ويدربهم علي تحمل المسئولية وممارسـة

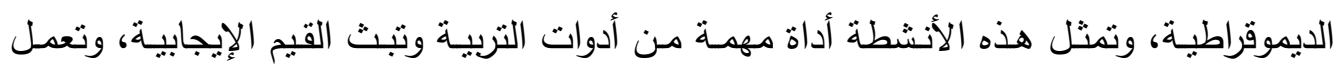

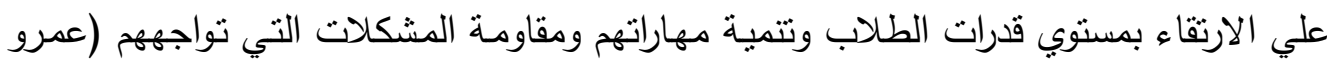

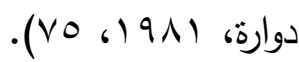

ويعتبـر المسرح الجـامعي وسيلة لإسـتثمار طاقـات الطـلاب فيمـا يفيد، فهو أداة فعالـة

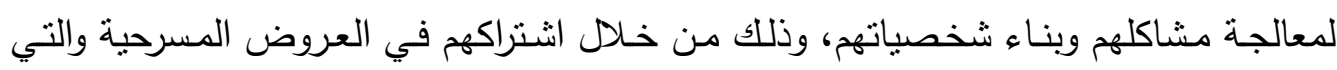

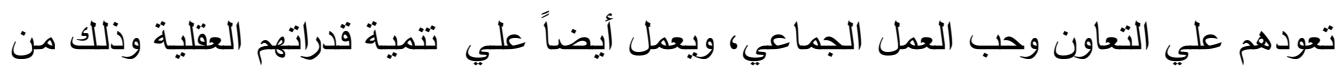

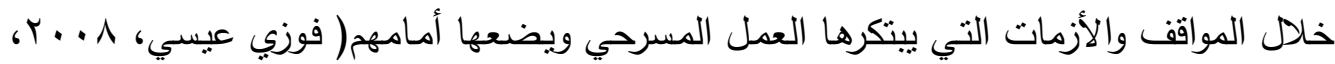




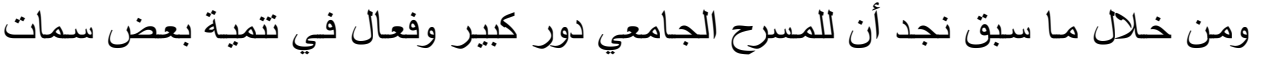

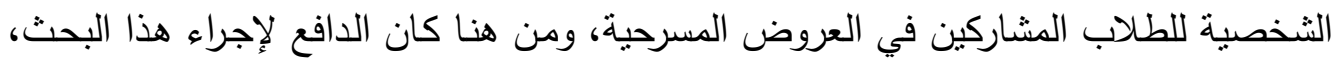

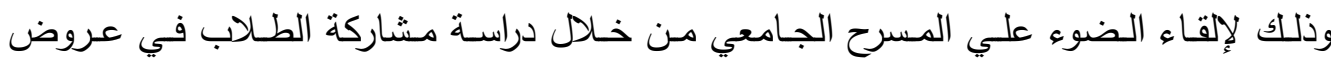

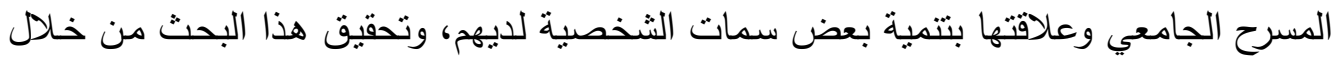

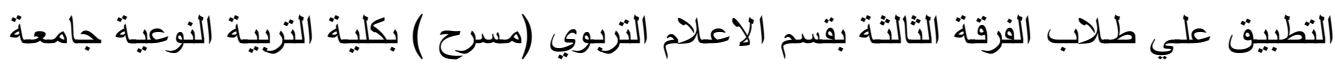
المنوفية.

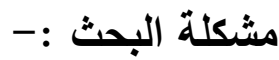

لوحظ أنه من خلال اشتراك الطلاب في عروض المسرح الجامعي أنه يعمل علي تتمية

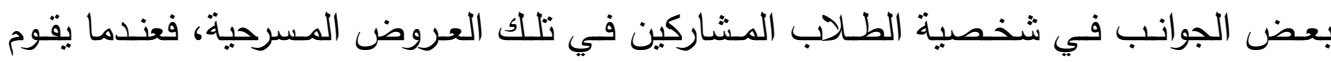

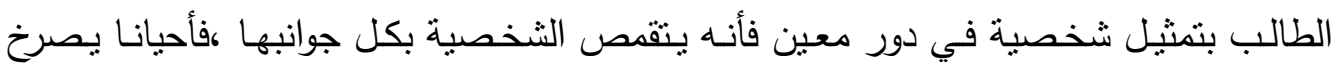

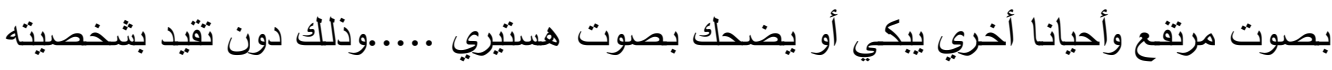

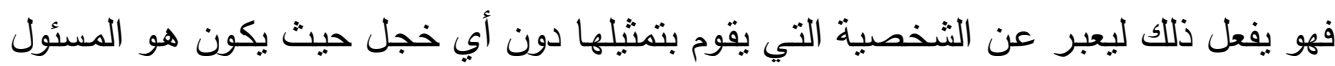

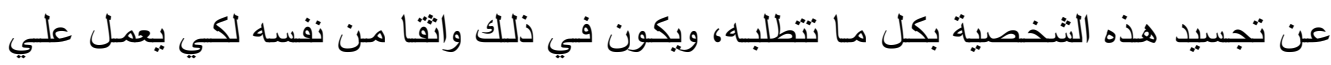

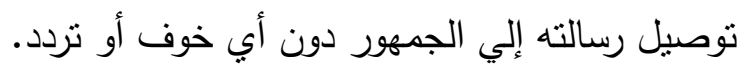

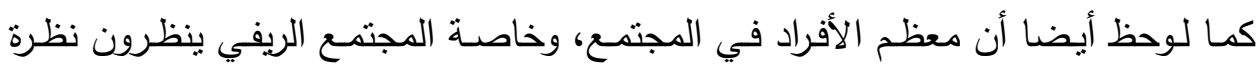

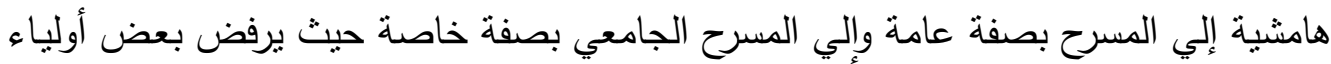

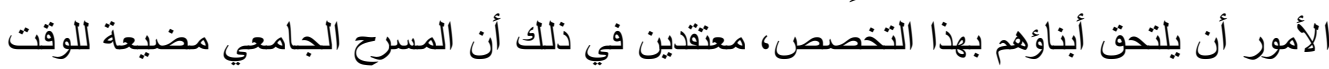

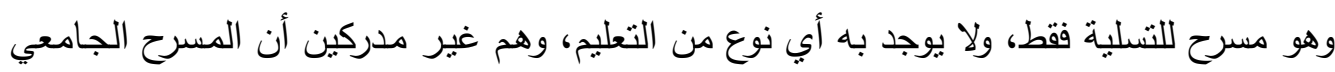

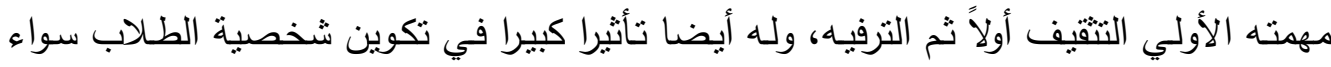

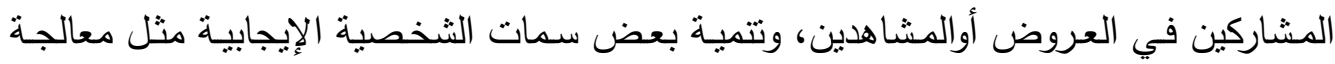
الإنطوائية، وفقدان ثقة الطالب بنفساه، وقدرته علي تحمل المسئولية.

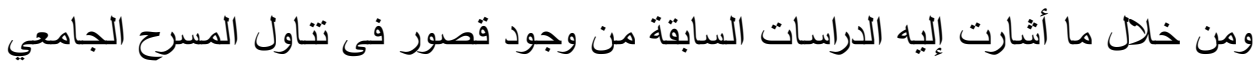

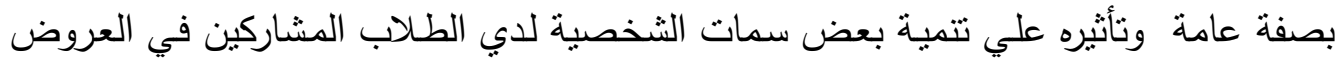

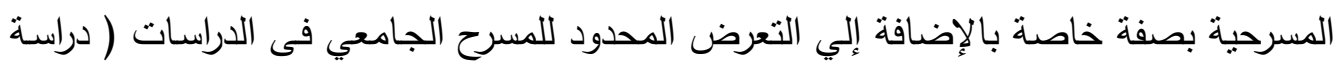

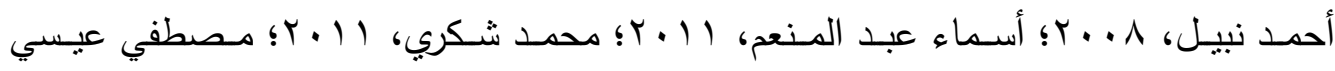

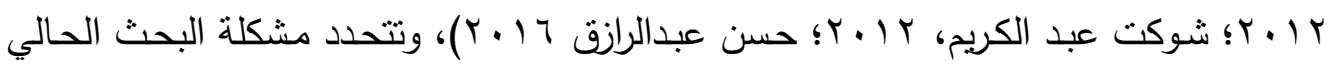

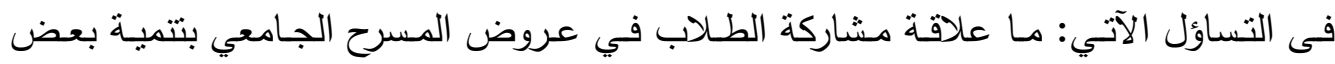

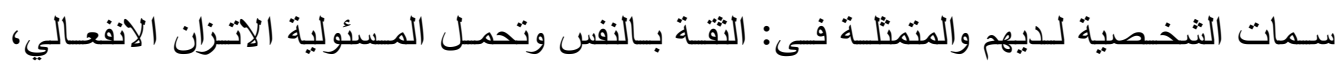
والإنطوائية ؟ 


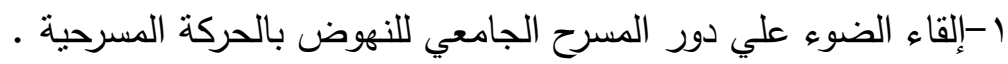

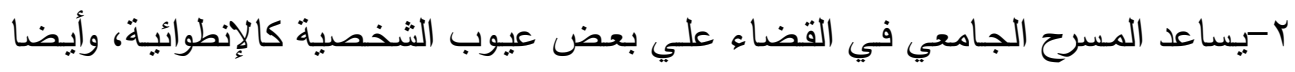
يساعد الطلاب علي تكوين العلاقات الاجتماعية مع الآخرين.

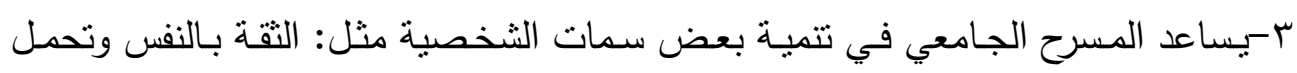
المسئولية الاتزان الانفعالي لدي الطلاب المشاركين في العروض المبات المسرحية.

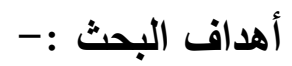

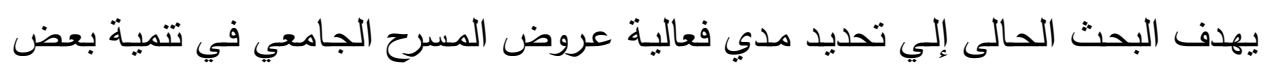
سمات الثخصية لدي الطلاب المشاركين في تلإلك العروض.

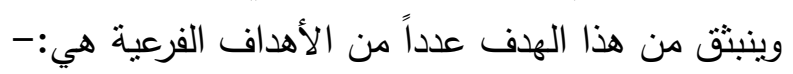

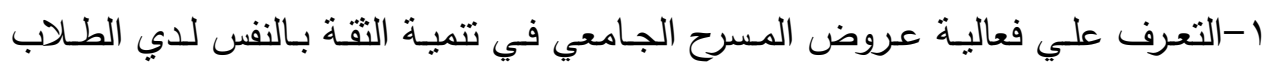

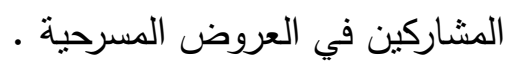

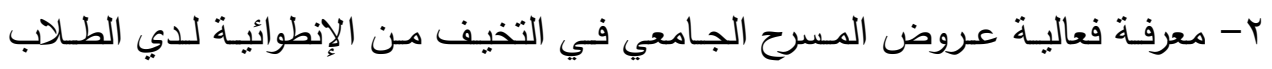
المشاركين في العروض المسرحية.

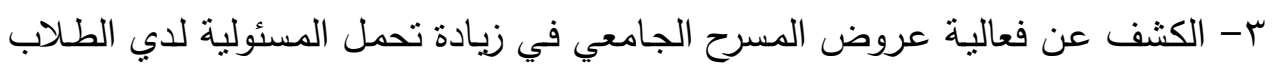

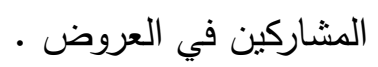

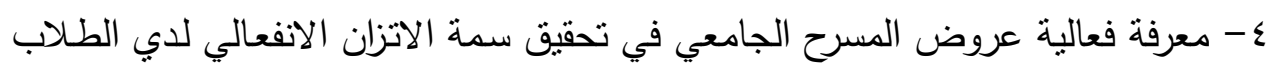
المشاركين في العروض المسرحية.

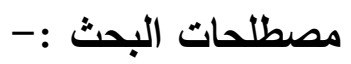

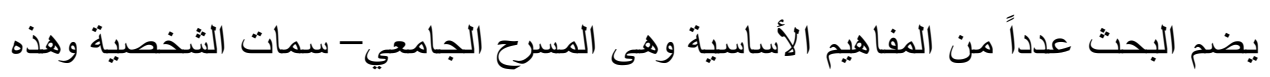

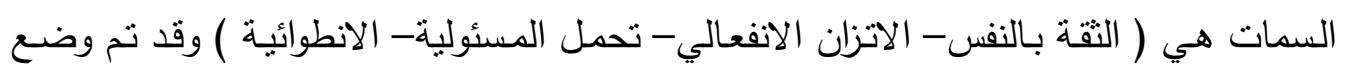

$$
\text { 1-المسرحات اجرائية لهم كالآتي:- }
$$

هو ذللك المسرح الذي يتكون من الفرق الرسمية بالجامعات، التي تقدم نشاطا مسرحيا

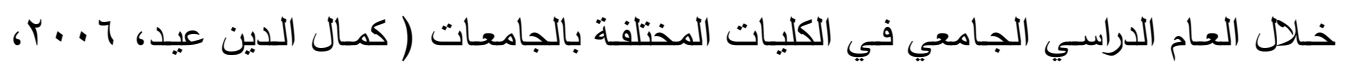

وتعرفه الباحثة إجرائياً بأنه: " ذلك المسرح الذي يخاطب قطاع شباب الجامعة، ويتيح لهم

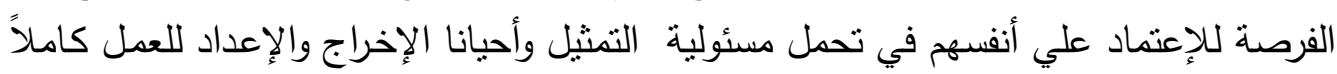

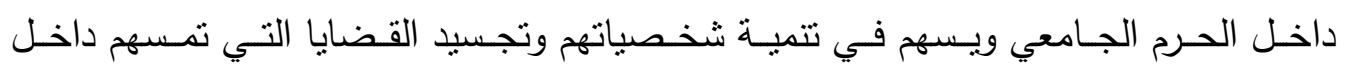




\section{r-سمات الثخصية :-}

"هي مجموعة من الصفات المزاجية التي تميز فردا عن غيره"( هبة عبد الحليم، ^ . . r، ه). ويقصد بها إجرائيا "أنها مجموعة من الأفعال السلوكية التي تتسم بالدوام النسبي وقد تكون التهن وراثية أومكتسبة أو متعلقة بمواقف اجتماعية، وتقتصر الدراسة علي بعض السمات وهي النهات الثقة بالنفس - الإنطوائية - تحمل المسئولية - الاتزان الانفعالي.

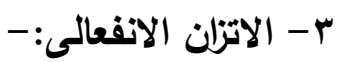

الـشخص المتـزن انفعاليـا هـ "ثـخص يتفاعـل بـدون تطـرف مـع المواقـف الانفعاليـة،

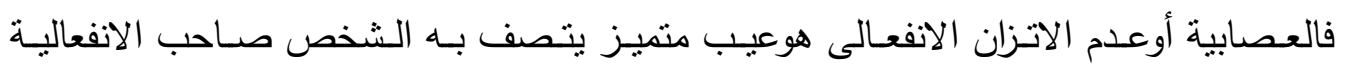

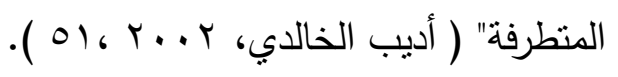
"أو هو التحكم والسيطرة على الإنفعالات والتعامل بمرونة مع المواقف والأحداث الجارية ، التهات

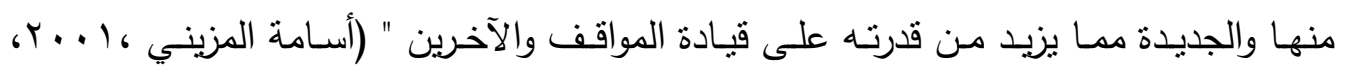

والاتزان الانفعالى مقابل العصابية هو" حالة الثـعور بالرضـا والسعادة نتيجة تكامل الفرد

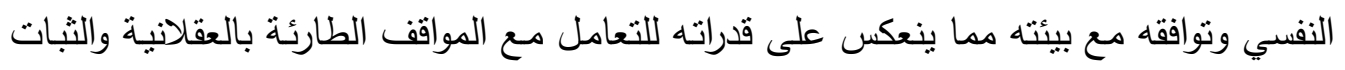

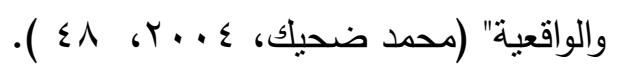
ويعرف إجرائياً بأنه "قدرة الفرد على ضبط انفعالاته فى المواقف الحياتية المختلفة والتعبير

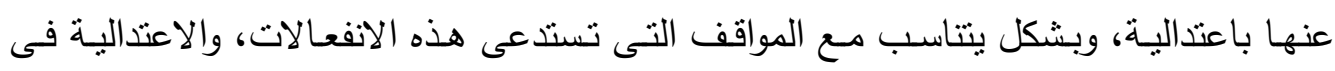

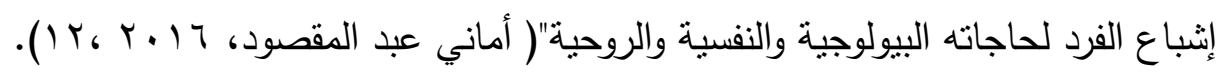
ع - تحمل المسئولية :-

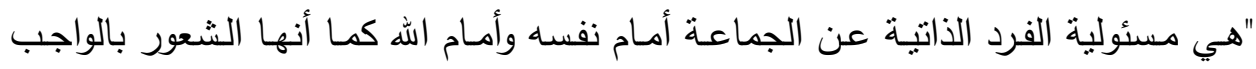

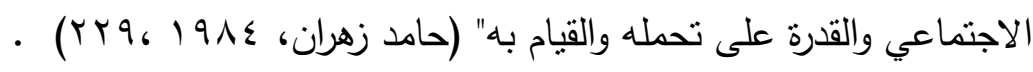

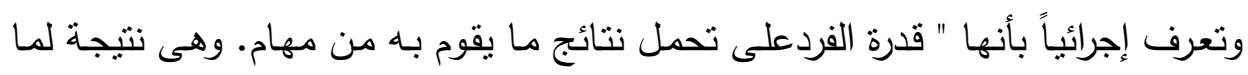

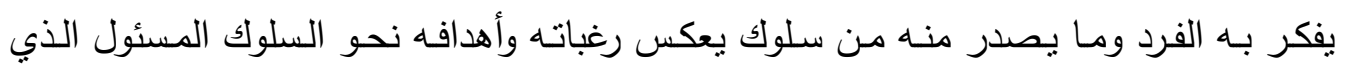
يتضمن الاهتمام بـالآخرين واحترام تقاليدهم وحقوقهم وقيمهم الاجتماعية والشعور بالمسؤولية

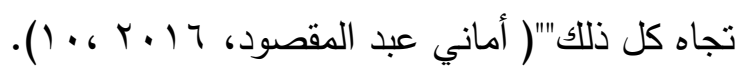
ه-الثقة بالنفس :- 
"هي تماسك الثخصية من خـال اتصالها بـاله والآخرين ووقوف الشخص وقوفاً سليماً دقيقأ علي واقعه الذاتي والاجتماعي من غير أن تسيطر علي ذهنه مفاهيم خاطئة عن نفسه"

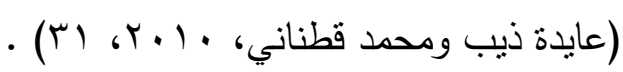
وتعـرف إجرائيـاً بأنهـا "إدراك الفـرد لإمكانيـة نجاحسه فـى التعامـل بفاعليـة مـع الآخـرين

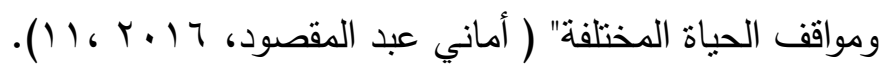
ج-الانطوائية :- ومواعباة

المنطوي هو شخص هادئ منسح، ومنأمل مولع بالمطالعة والدراسة، ومتحفظ ومترفع إلا

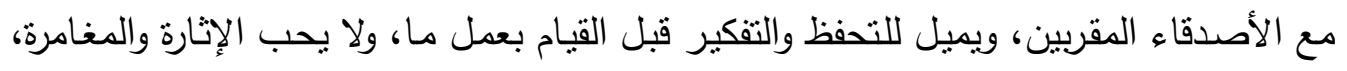
ويـضبط مشاعره بقوة ونـادراً مـا يكون عدواني، وهو متشائم ويعطي قيمـة للمعـايير الخلقيـة

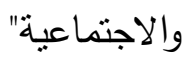
وتعرف إجرائياً بأنها "موقف يتخذه الفرد من المجتمع بحيث يتفادى الاحتكاك بالمجتمع

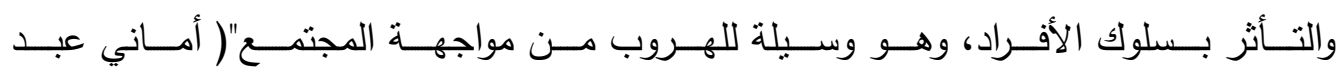

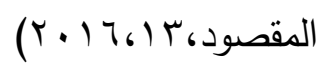
الإطار النظري والمفاهيم الأساسية: المحور الأول: المسرح الجامعي:-

المسرح الجامعي هو مؤسسة للأجيال به تهذب النفوس ويسمو بالعقول، و يسهم في عملية التعادل بين أنواع المعارف التي تنقل ذاكرة الطالب، وتتكامل من خلالها ذاتيته فتخرج منه كائنا حيا يستشرق الحياة بقوي متكافئة من صحة البدن، وسـلامة الفكر ، وطهارة الخلق وفهم وولاء

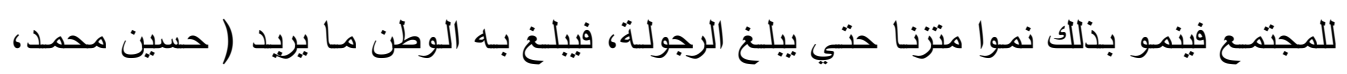

$$
\cdot(r, r \cdot .9
$$

ويعتبر المسرح الجامعي عملاً جماعياً تتكامل فيه جميع عناصـرالعرض المسرحي من ملابس، ديكور، وموسيقي، ورسم ... حيث يكمل كل منهمل الآخر، ولا يقتصر الأمر عند فن فئن

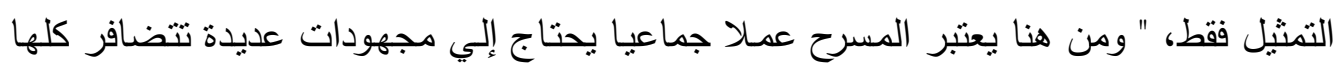

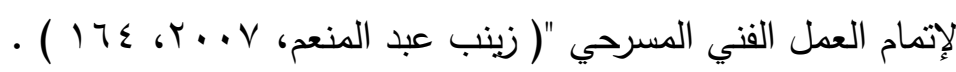

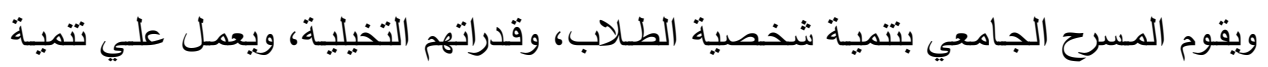

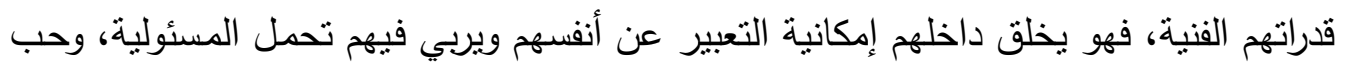

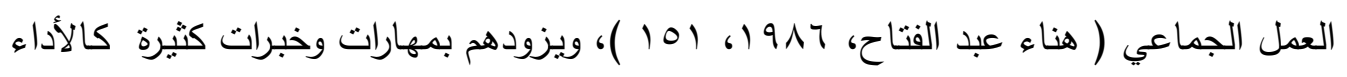




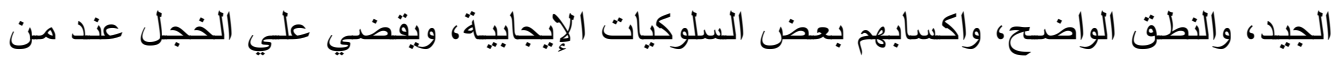

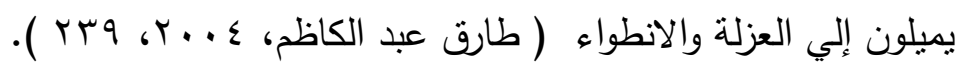

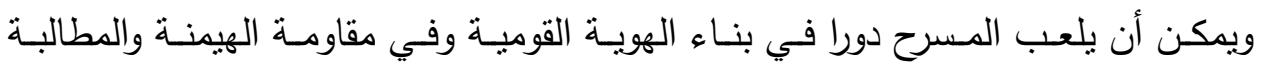

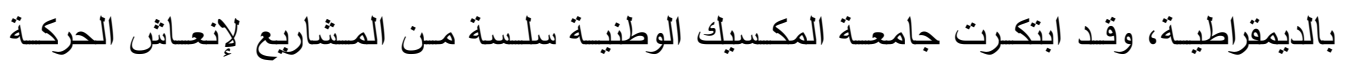

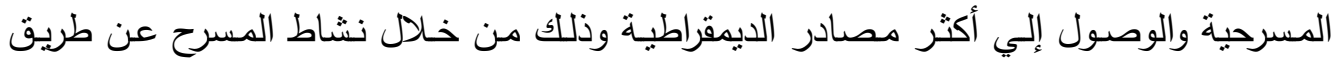

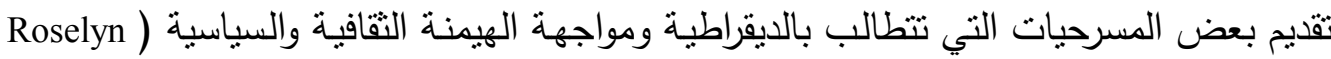
.Costantino , 1995,p4

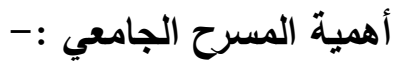

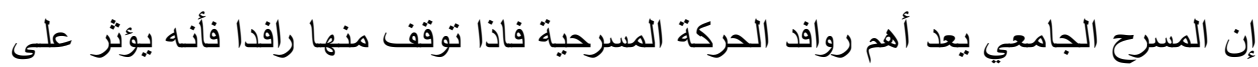

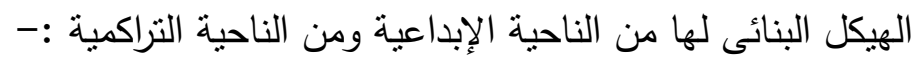

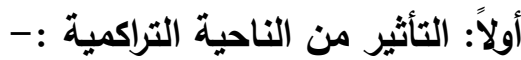

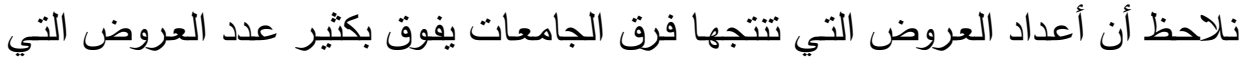

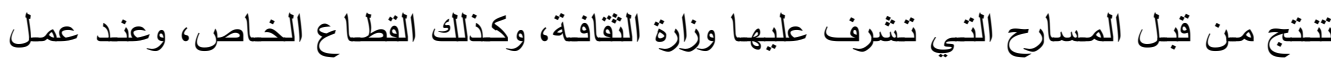

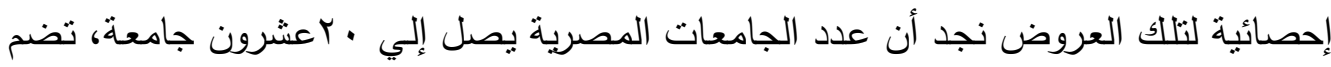

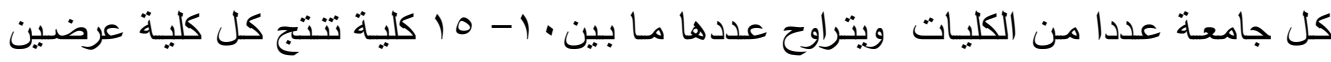

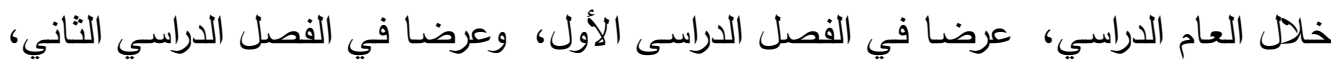

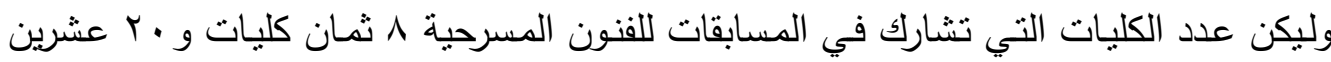

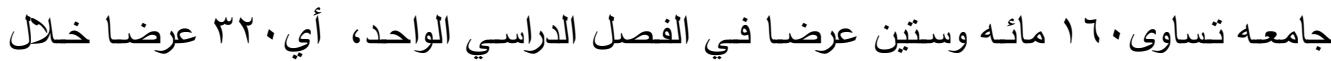

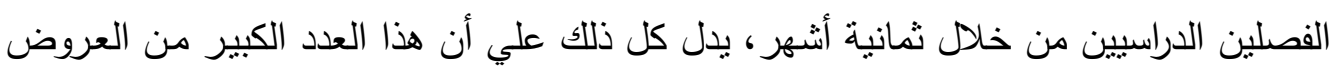

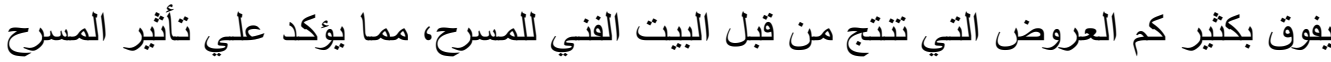
الجامعي علي النهوض بالمسرح والحركة المسرحية من حيث عدد العروض لبن (مصطفي عيسي، . (19. T. T

\section{ثانياً :التأثير من الناحية الإبداعية :-}

يؤثر المسرح الجامعي على الحركة المسرحية من حيث الناحية الإبداعية حيث يقوم بالتطوير المستمر للحركة المسرحية، عن طريق إمداد المسرح بعدد مـن الشباب الموهوبين والقادرين علي مواكبة كل التطورات الحديثة بكل ما يمتلكونه من أفكار جديدة وإبداعية ، والدليل على ذللك اثتراكهم في العديد من دورات المهرجان القومي للمسرح المصري، حيث اثتنركت جامعة عين شمس في الدورة الثانية بالعرض المسرحي (الإكليل والعصفور )، تأليف أسامه نور

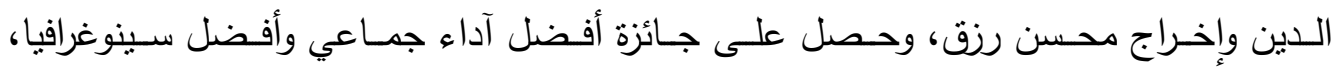


واشتركت جامعة عين شمس أيضاً بالعرض المسرحي ( روميو وجوليت) إعداد وإخراج محمد الصغير وحصل علي جائزة أفضل عرض مسرحي ولا يوجد أوضح من هذا دليل على تأثنير

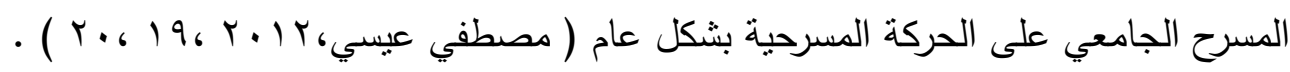

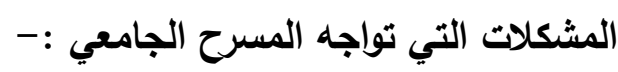

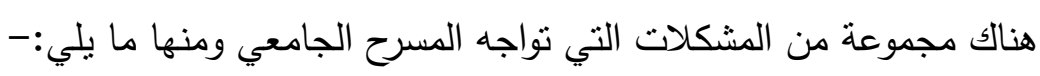

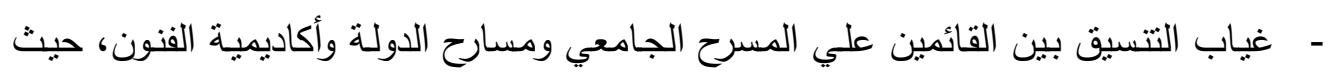
بمكن الإستفادة من عروض المسرح الجامعي من خـلا إعادة تقديم تلك العروض أمسام

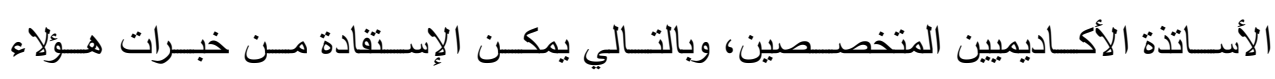
المتخصصين. - عدم توفر الأماكن والمنصات المجهزة للتدريب وإجراء البروفات وكذللك لإستقبال العروض مئل

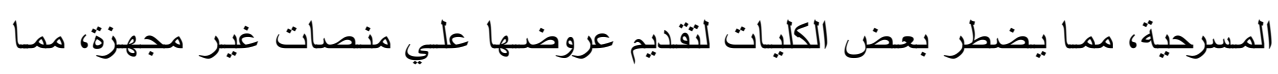

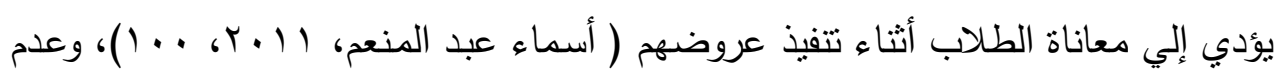
إقامة ورش عمل لفريق التمثيل في كثير من الأحيان، وذلك لضعف الإمكانيات المتاحة

وعم وجود قاعات مجهزة.

- ـ ضـعف الحوافز المادية والمعنويـة والتي تؤدي إلي عدم حماس الطلبة للإنخراط بالأنشطة ومن جانب آخر؛ عدم إهتمامهم بـالإطلاع على الإعلانات والكتيبات التي تتشرها إدارة

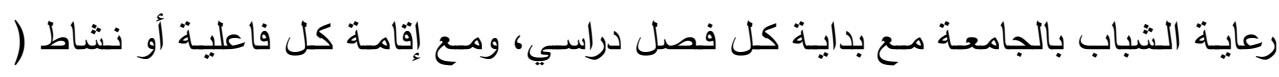

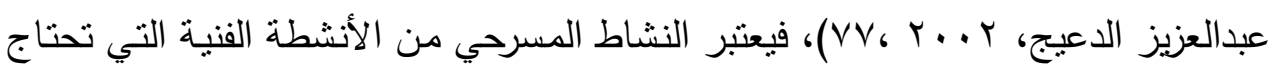
إلي ميزانيات كبيرة، حيث يمثل التمويل أحد عناصر نجاحه، فلا يتصور وجئر ونود مسرح فعال

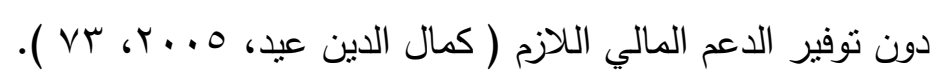

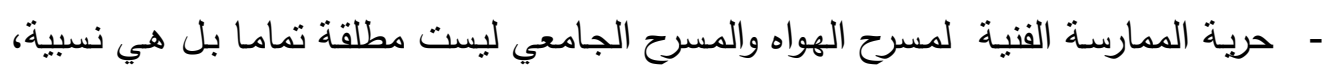

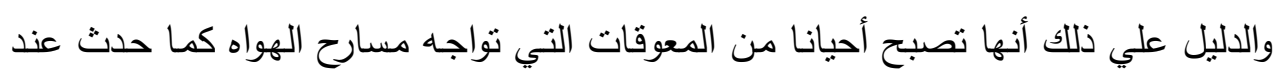
إلغاء التصريح بالعرض وعدم منح الترخيص لبعض العروض مثل البرقيات لفرقة مجانين

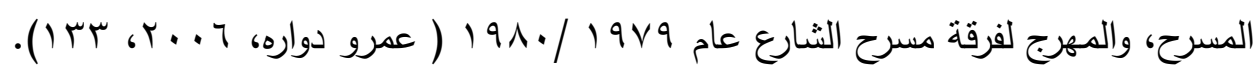

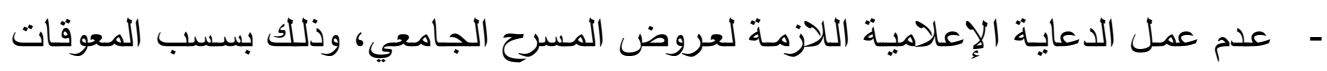

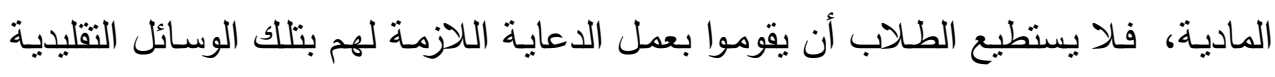


في أجزة الإعلام لضعف الامكانيات المالية المتاحة من الجامعة ( عمرو دواره، ب99 1، . ( r 10 - ربما تكون نظرة المجتمع إلـي الفن المسرحي هي أكبر المعوقات الاجتماعية التي تواجهـ

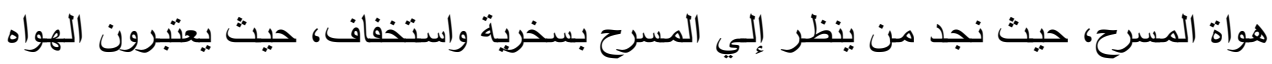
بأنهم لا يمتلكون الموهبة لإخراج تلك العروض الكبيرة، وينظرون إليهم بأنهم مجرد مبتدئين

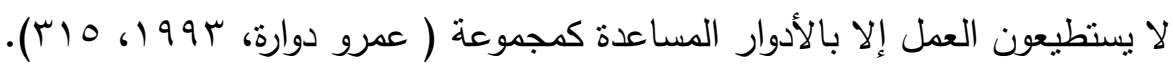

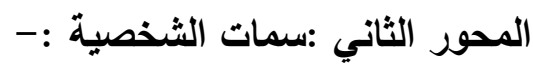
لقد أصبح موضوع الثخصية من أهم الموضوعات التي تحتل مكانة كبيرة بين فروع علم النفس، فلكل شخصية سماتها، والتي تحدد خصائص هذه الثخصية ونقاط ضـعفها وقوتها

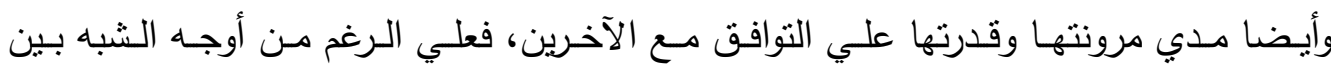

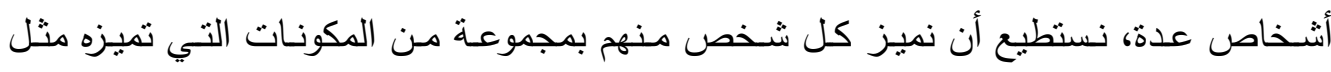

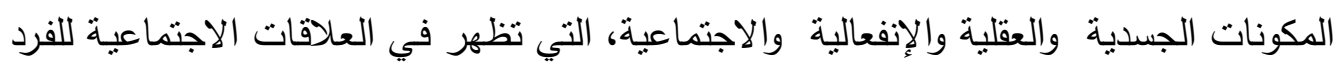
بعينه وتميزه عن غيره . لقد اهنم العلماء والباحثين بدراسة الثخصية الانسانية حيث أصبح الإنسان يعيش غريباً ألهاء

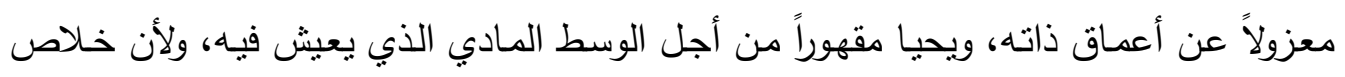

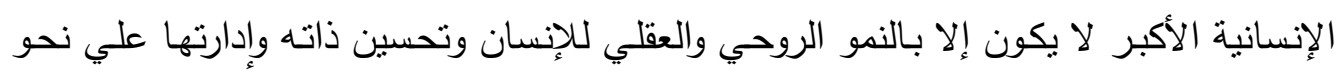

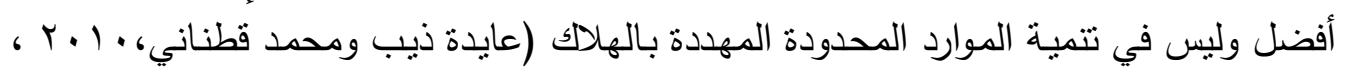
. 70

\section{مكونات الثخصية :-}

تعددت النظريات الديناميكية التي تهدف إلي دراسة مكونات النخصية ومن هذه المكونات:-

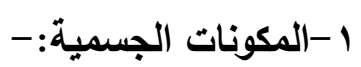

هي التي تتعلق بالشكل العام للفرد وصحته من الناحية الجسمية، وأهم هذه المكونـات

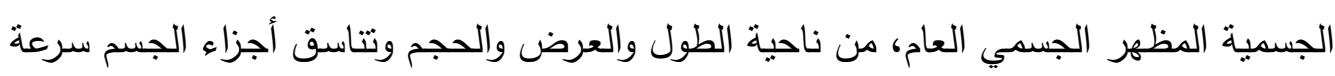

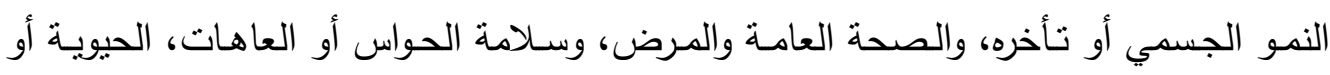

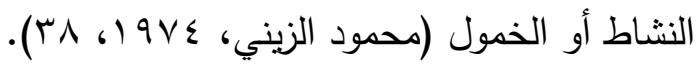

$$
\begin{aligned}
& \text { r-المكونات المعرفية :- }
\end{aligned}
$$

هـي التـي تتعلـق بالوظـائف العقليـة العليـا مثـل الـذكاء، والاسـتعدادات العقليـة الخاصــة

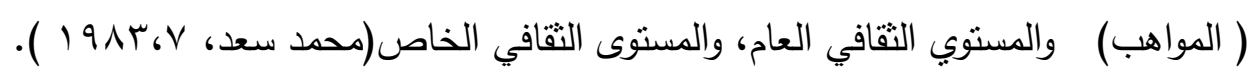


هي مجموعة الصفات الاففعالية المميزة للفرد، وتتضمن تلك الاستعدادات الثابتة نسبياً والمثبتة على ما عند الثخص مثل الطاقة الانفعالية والدوافع الغريزية التي يزود بها والتي تعتبر

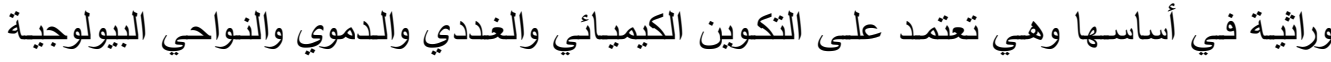

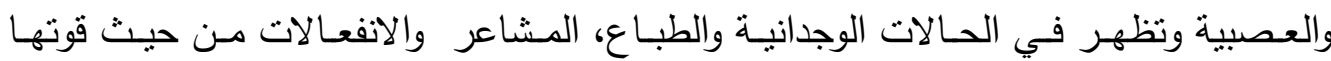

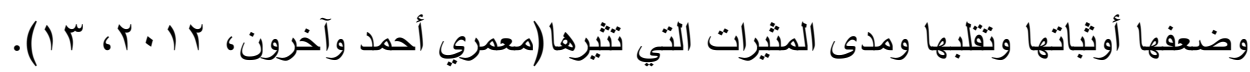

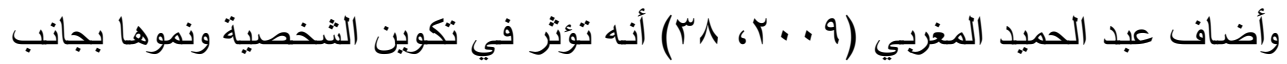

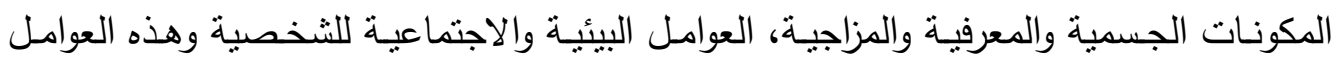

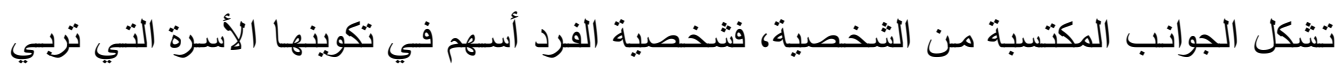

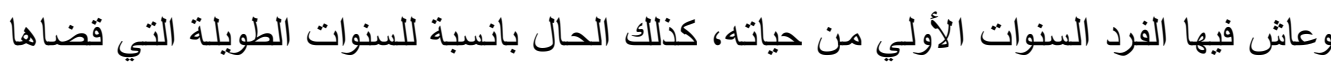
الفرد في المدرسة واكتسب فيها الكثير من الخبرات الاجتماعية والثقافية والمهنية.

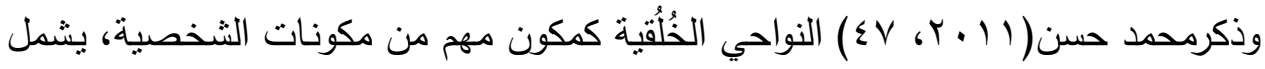

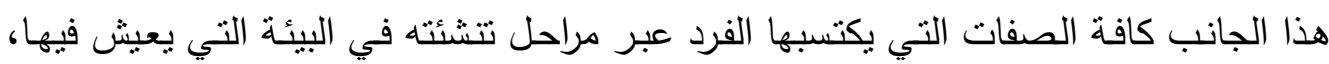

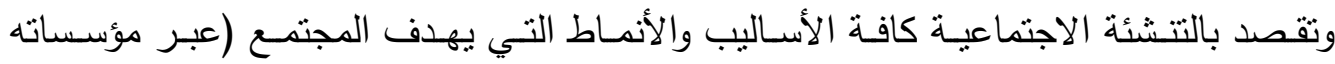
الاجتماعية والتعليمية والاعلامية والدينية المختلفة ) غرسها في سلوك الأفراد، وعادة ما تمثنل

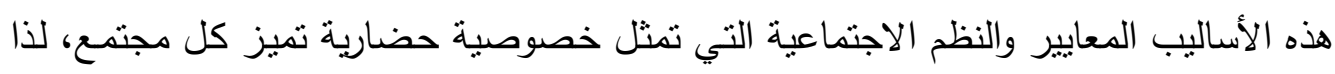

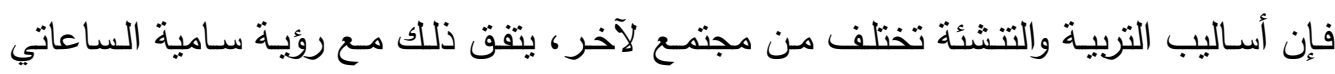

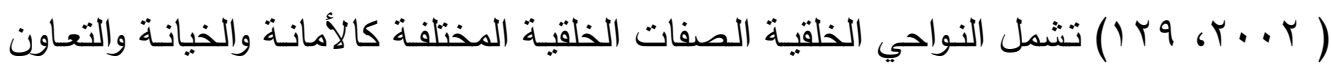
والأنانية والصدق والكذب والرحمة والغلظة والعدل.

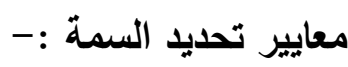
وضع "ألبورت Albort " ثمانية معايير لتحديد السمة جاءت علي النحو التالي:1-السمة لها أكثر من وجود نسبي (بمعني أنها عادات علي مستوي أكثر تعقيداً ).

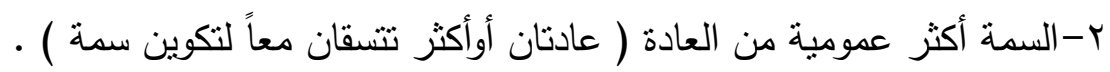

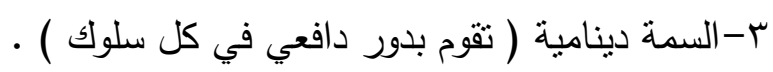
ع-وجود السمة يمكن أن بتحدد تجريبيا أو إحصائياً .

ه-السمات ليست مستقلة بعضها عن بعض ( ولكنها ترتبط عادة فيما بينها ) .

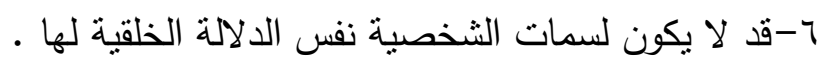

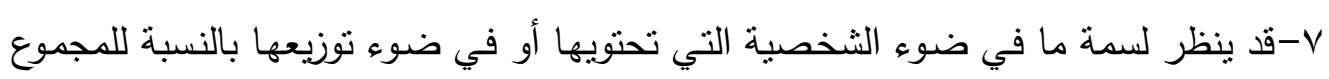

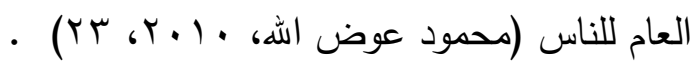


اهتم الباحثون في مجال السلوك الانساني بوضع نظريات في الثخصية، والنظريات هي

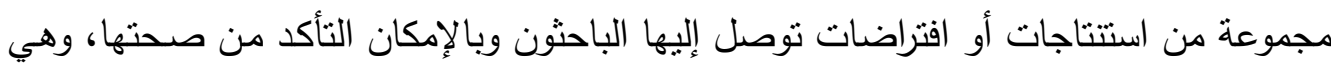

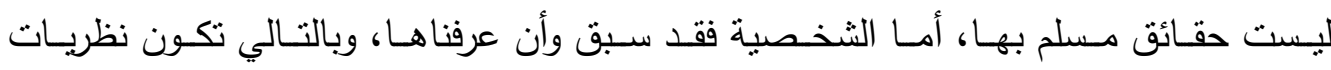

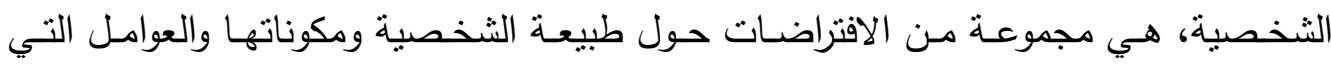
تساعد في تكوينها، وتعددت الاسـتنتاجات حـول الثخصية الانسانية ممـا أدي إلـي ظهور

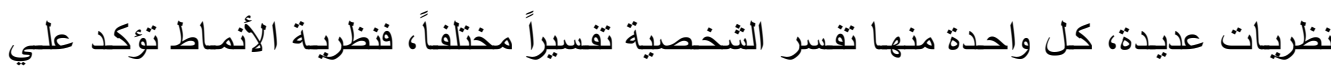
المقارنة بين الأفراد علي أساس مجموعة من الخصائص الجسمية والنفسية، أما نظرية التحليل

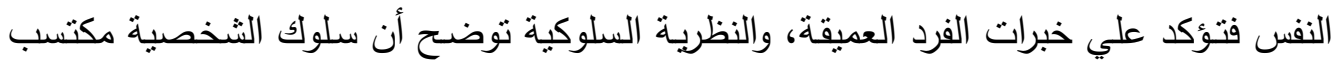
ويمكن تعديله، ونظرية السمات تؤكد علي الفروق الفردية بين الأفراد وأن لكل فرد سمات معينة

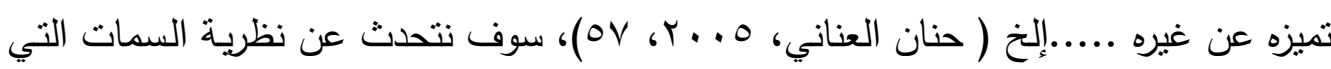
من شأنها إلقاء الضوء علي موضوع الدراسة الحالية :-

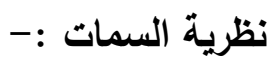

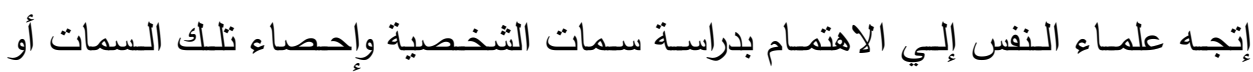
الصفات التي تميز شخصاً عن غيره، وحاولوا تقدير هذه السمات تقديراً عددياً بقدر المستطاع الهاء

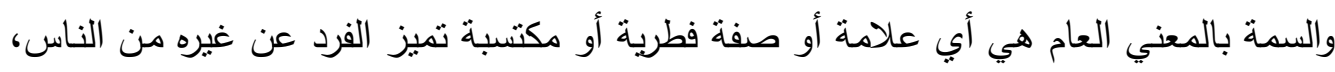

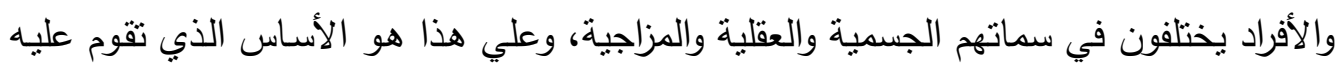

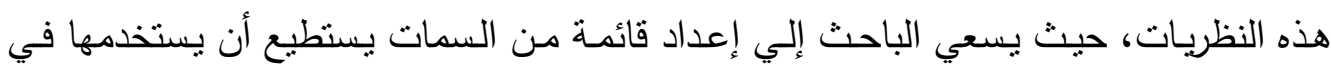

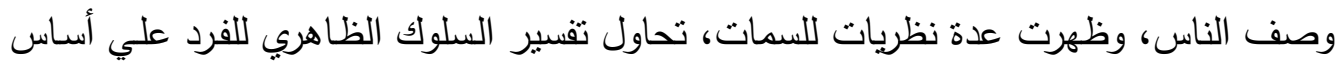
افتراض وجود هذه الاستعدادات المعينة المسئولة عن سلوكه، وعن الثبات النسبي الذي يتسم بـه

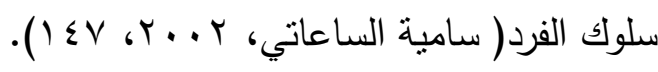

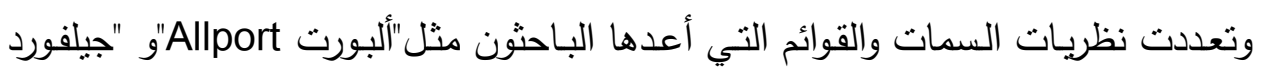
Guilford"و"كاتل "Cattel"و" "إيزنك وفيما يلي عرض لكل نظرية منهم علي حدة :أولاً : نظرية السمات عند ألبورت :يعتبر "جوردن ألبورت "من الرواد الأوائل الذين قاموا بدراسة السمات، فقد عرف الئد "ألبورت

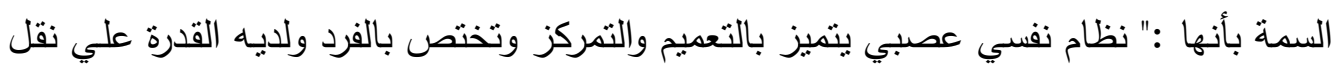




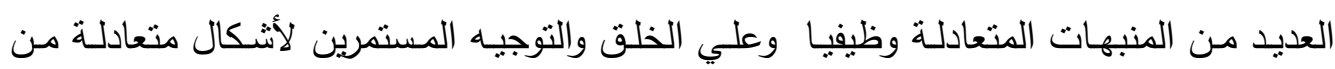

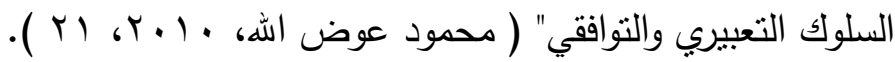

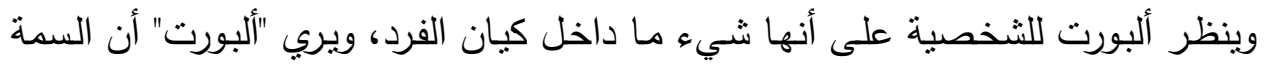

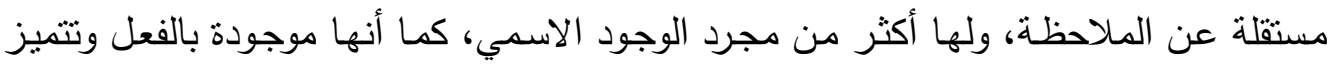

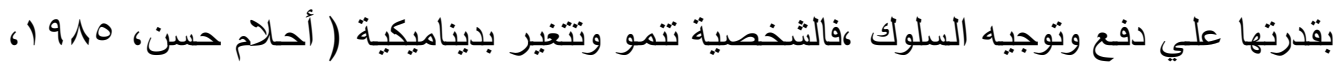

\section{ثانيا نظرية السمات عند جوي بول جيلقورد : -}

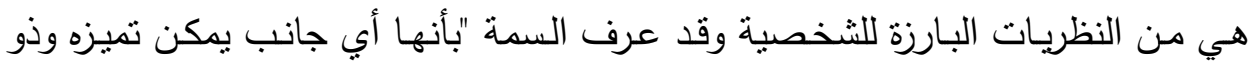

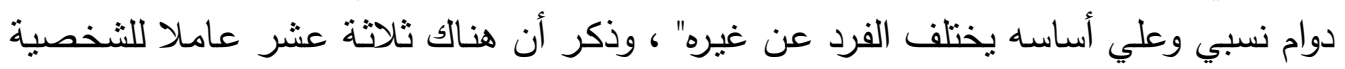

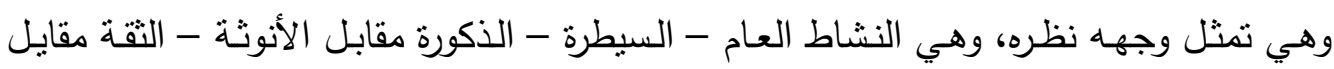

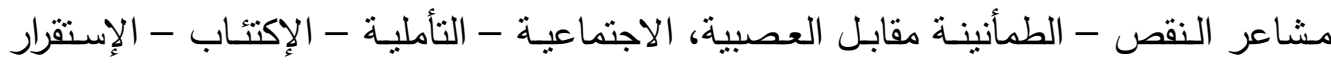

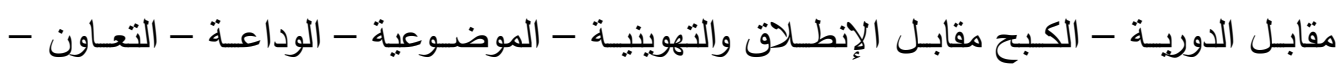

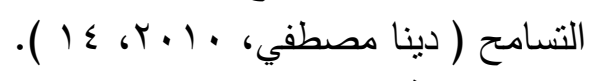

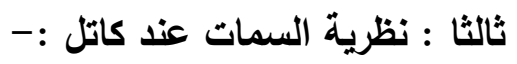

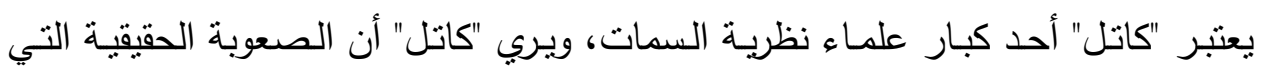

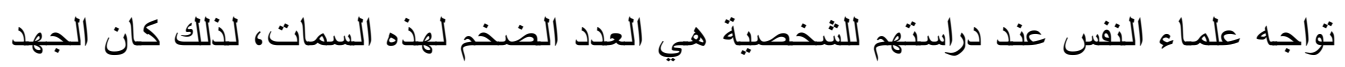

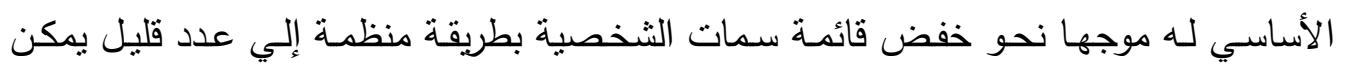
معالجته بواسطة الطريقة الإحصائية التي تعرف بائه باست التحليل العاملي ( محمد عز الدين، - (Or 6) 199 r

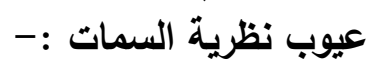

لنظرية السمات العديد من العيوب، ومن العسير تلافي هذه العيوب ومن أهم النقاط التي

$$
\text { تؤخذ علي نظرية السمات هي:- }
$$

1-استخدمت نظريـة السمات العديد مـن الاختبـارات الموضـوعية لقياس سمات الفرد، ولكن

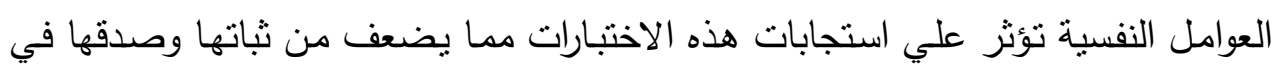
بعض الأحيان

ץ-مسألة وجود سمات عامـة نسبيا لا تزال مجالا مفتوحا للاراسـة والبحث ذلك أن مـا يفعله

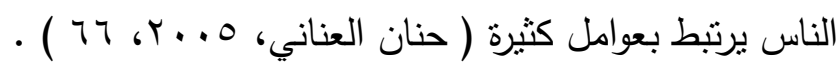
r-تنظر إلي السمات كموجودات داخل الفرد نفسه، ولكن الحقيقة ليست إلا طرقا للسلوك في

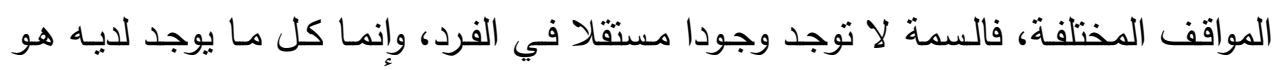

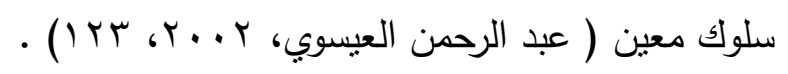


كما لكل نظرية مأخذ عليها فأيضا يوجد مميزات تتميز بها، ومن أهم المميزات التي تتسم

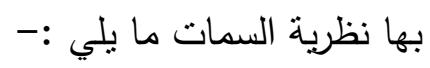

ا-1إن هذه النظرية تتحاشي النطرف الذي وقعت فيه نظرية الأنماط والني لا تري من الظواهر

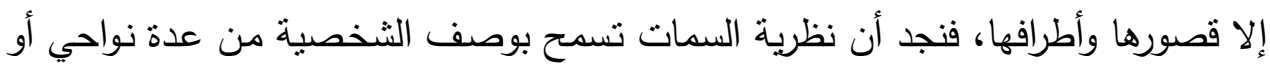

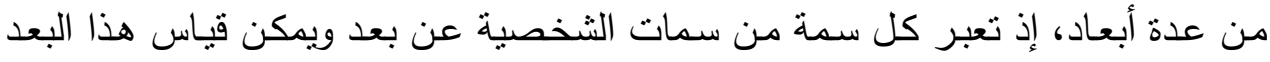

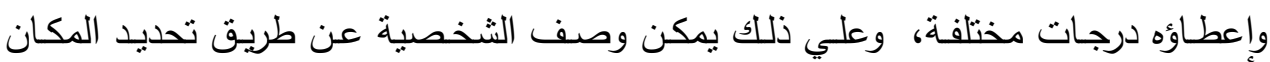

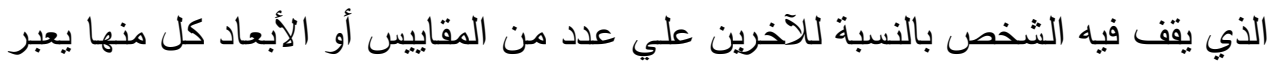

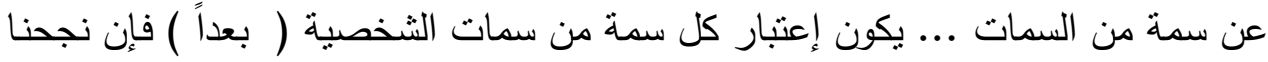

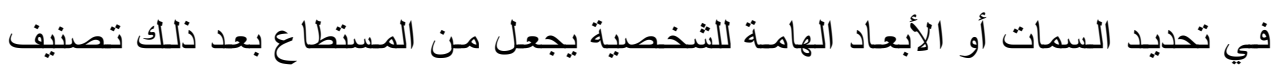
الثخص علي أساس رسم بروفايل له يشمل درجته في كل سمة أو بعد من الأبعاد.

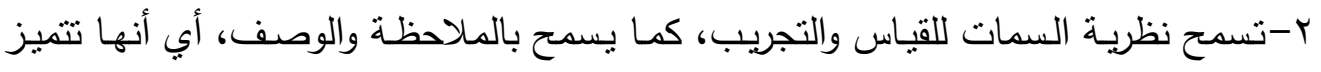

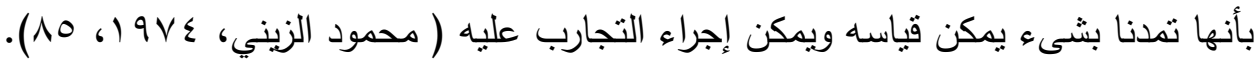

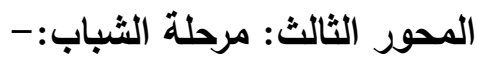

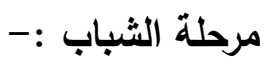

تعد مرحلة الثباب هي مرحلة التجريب لأدوار ومهام جديدة، وهي السن الذي يستعد فيه

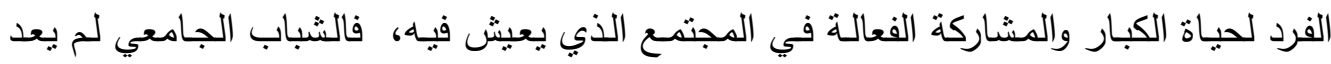

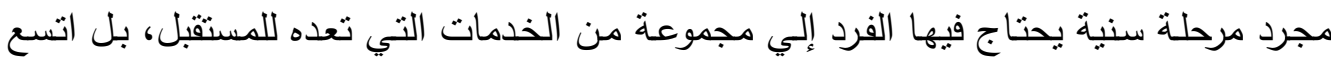

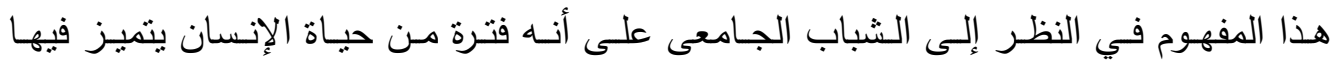

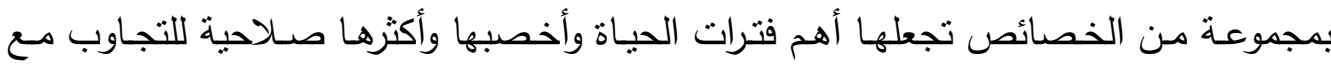

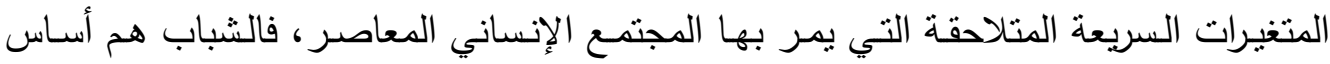

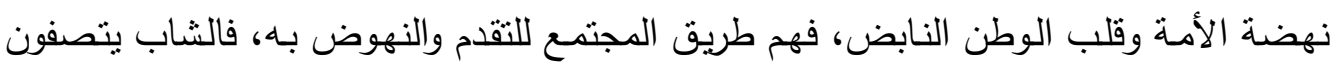

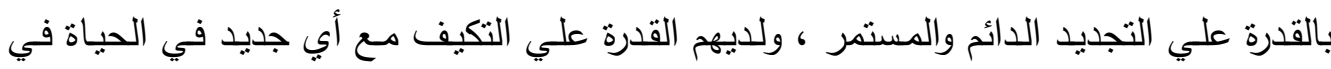
مختلف النواحي العلمية والسياسية والاجتماعية.

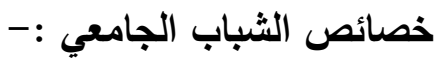

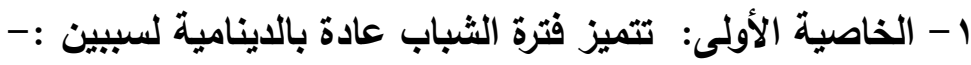

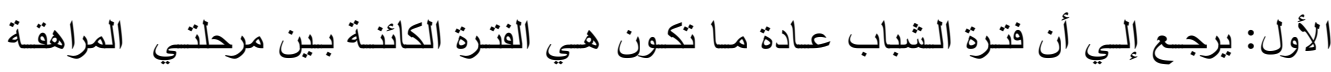

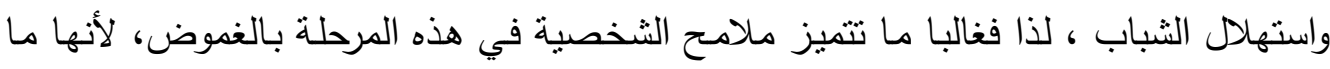

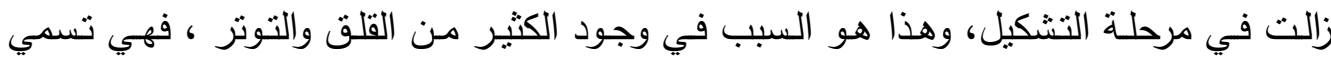


بمرحلـة مـا وراء الإسـتقلال، أمـا السبب الثاني: لديناميـة هذه المرحلـة فيرجع لطبيعـة التكوين

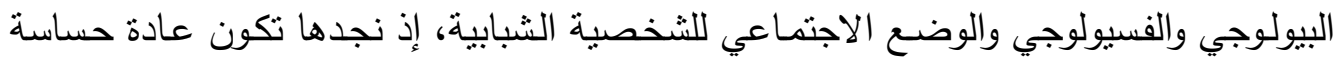

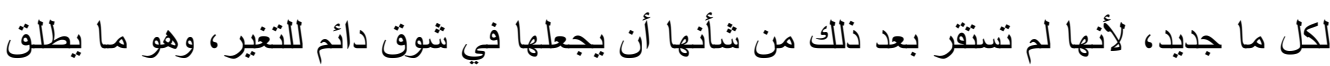

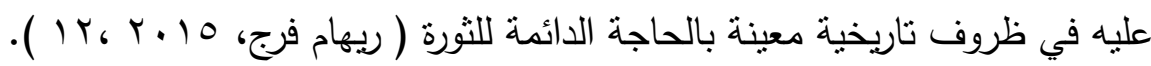
r- الخاصية الثانية : النظرة المستقبلية:لا تقوم الأمم ولا تنهض حضارتها دون جهود الشباب فيها؛ فالشباب هم عنصر القوة

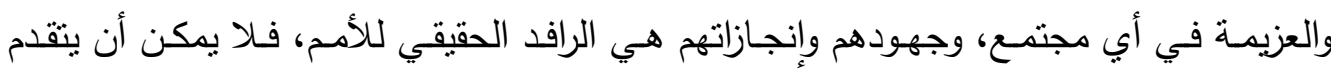

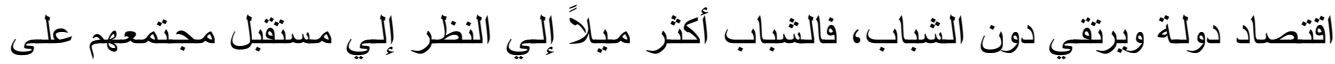

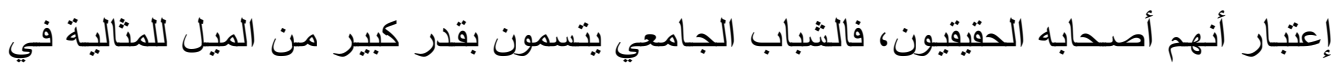

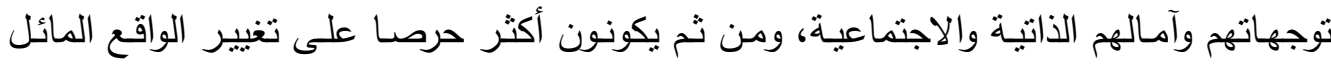

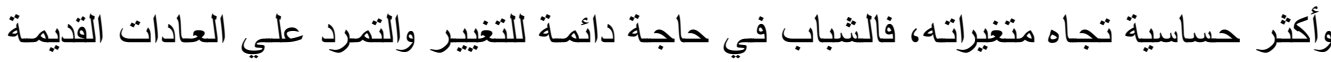

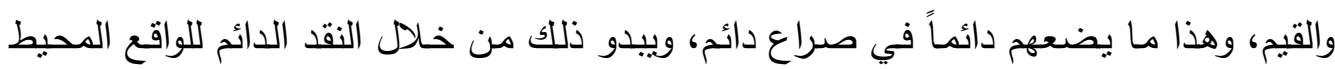

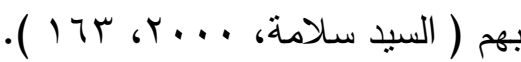

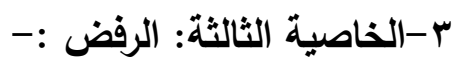

قد يكمن سبب الرفض في عدم إعتراف الكبار بالثباب ورفضهم لتصوراتهم ومزاحمتهم

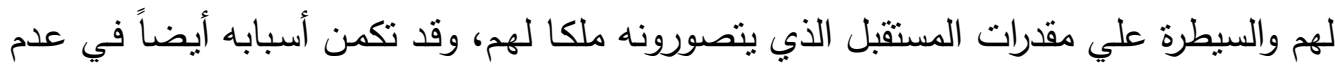

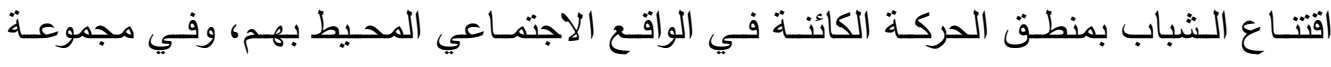

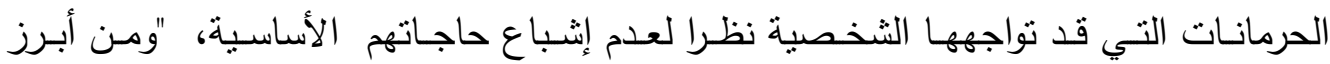
مظاهر ظاهرة الرفض عند الثباب ما حدث في ثورة مايو 971 19، عندما حاول الثباب إثبات

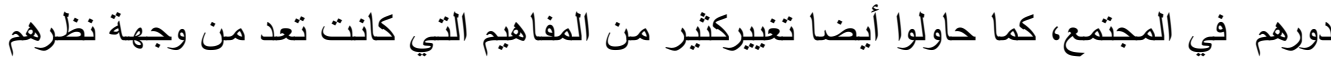

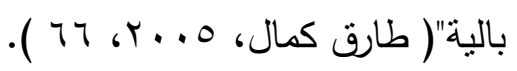

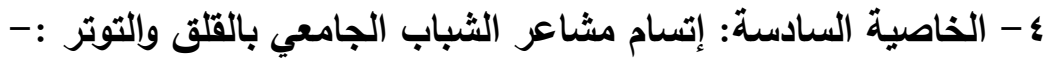

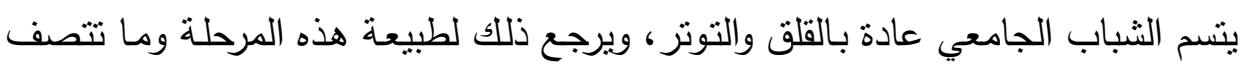

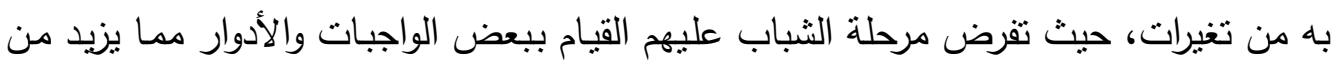

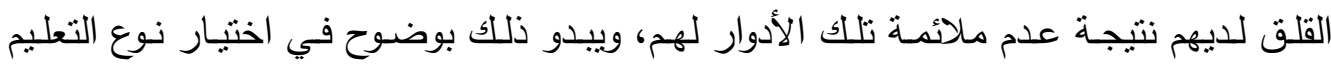

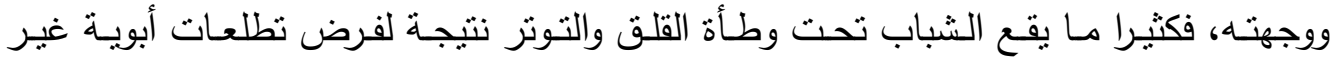
الواقعية في تحدي وجهته التعليمة، أو نتيجة لوقوف مكاتب تتسيق القبول بالجامعات بينهاته وبين

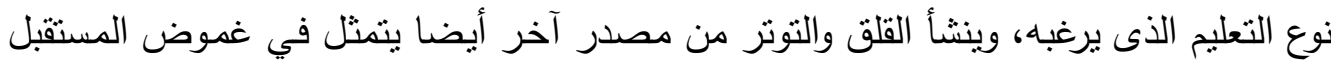

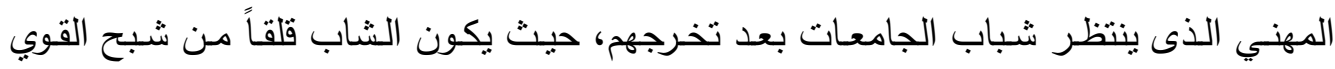

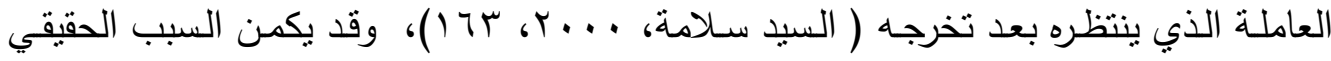


لقلق الشباب الجامعي من المستقبل، في تدني المستويات الاجتماعيـة والثقافيـة والإقتصادية،

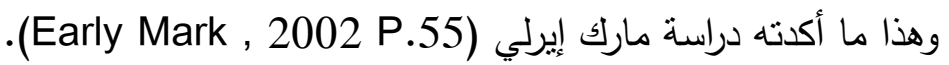

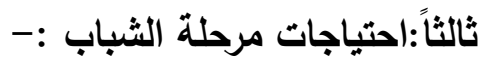

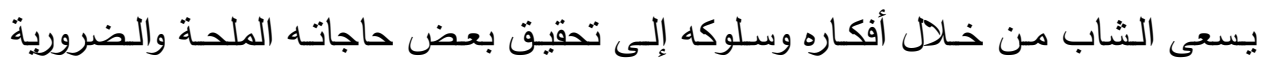

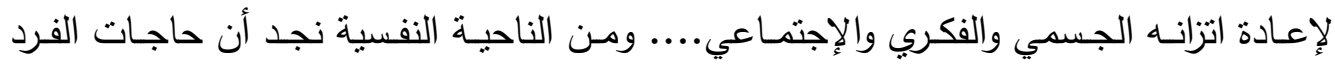

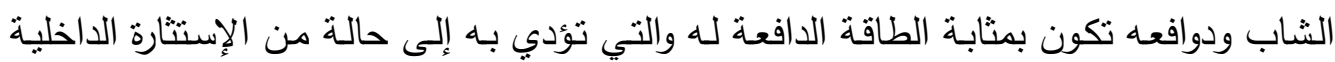

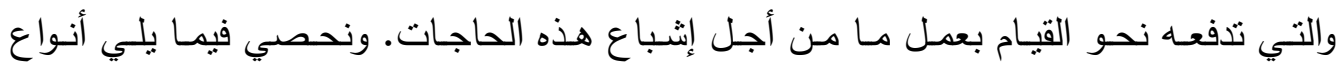

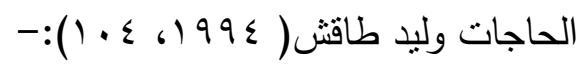

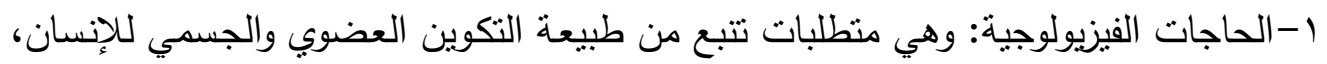

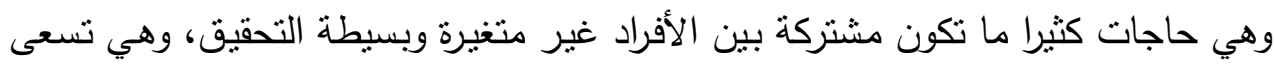

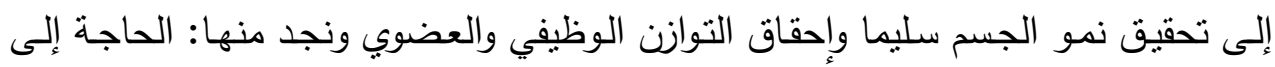

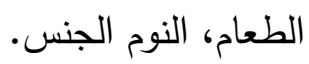
ץ-الحاجـات النفسية الوجدانية: وهي حاجـات تعمل على تحقيق النوازن النفسي لدى الفرد،

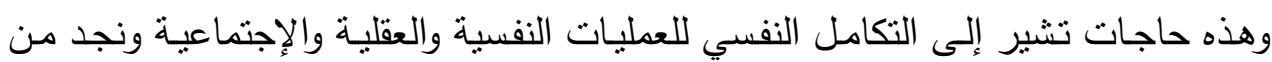

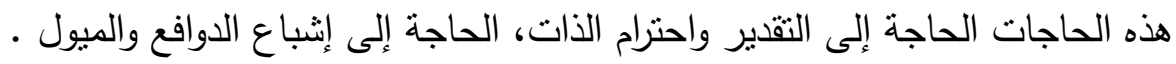

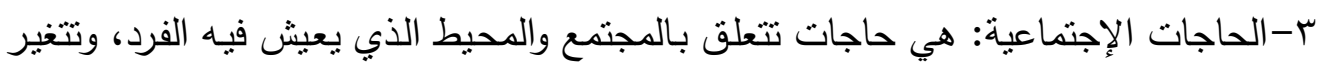

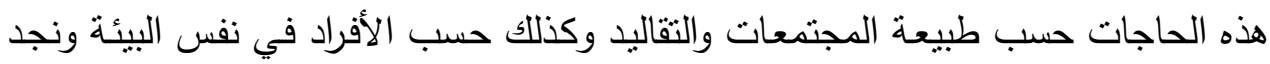

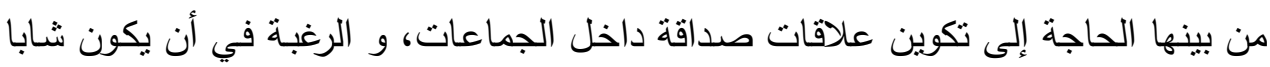

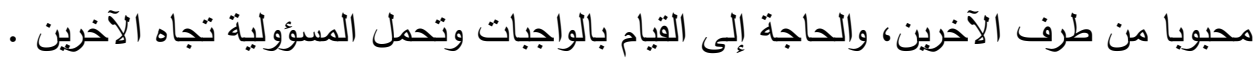
دراسات سابقة:

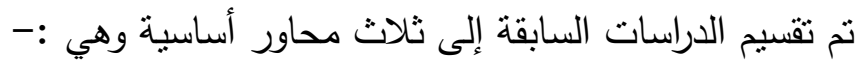

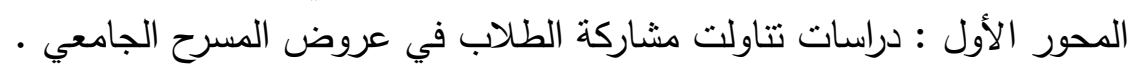

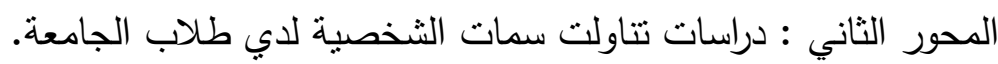

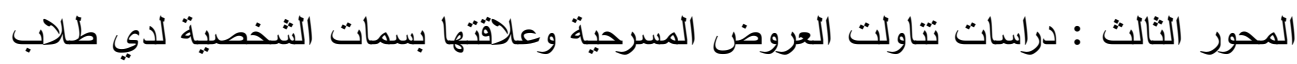
الجامعة .

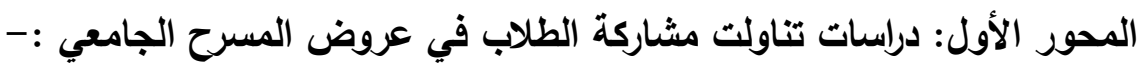

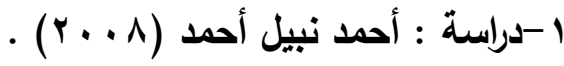

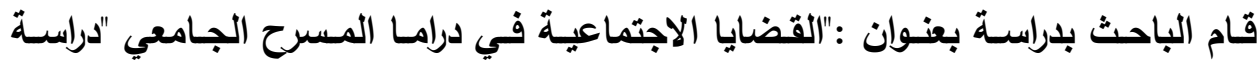

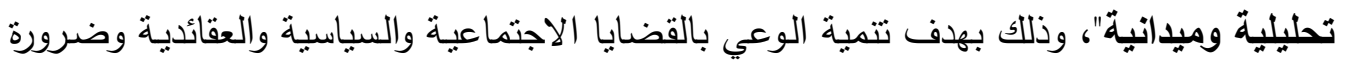

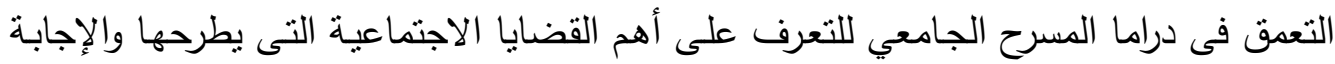

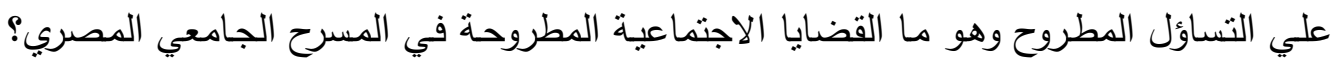


وتتتمي هذه الدراسة إلي الدراسات الوصفية والتي تعتمد علي منهج المسح ،واستخدمت المنهج

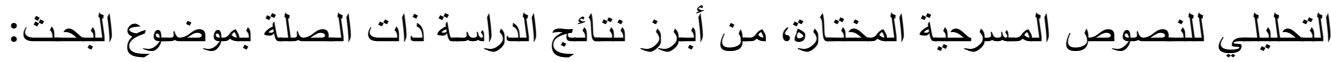

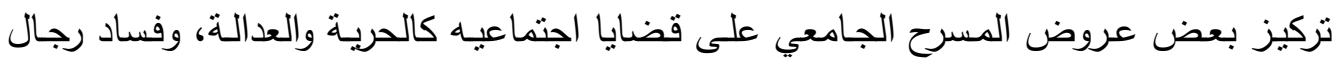

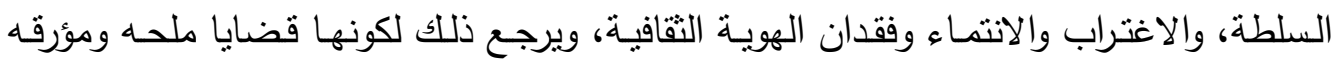

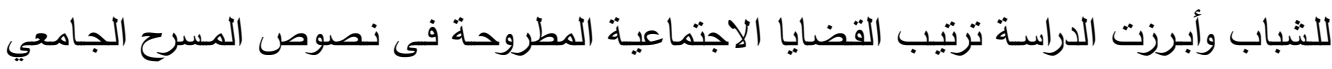

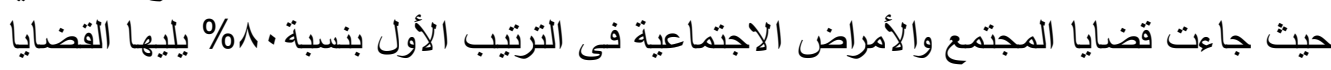

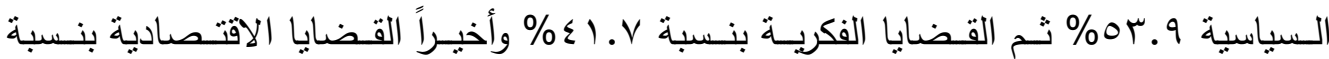

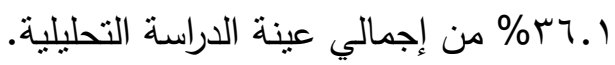

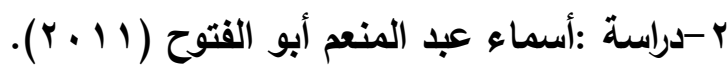

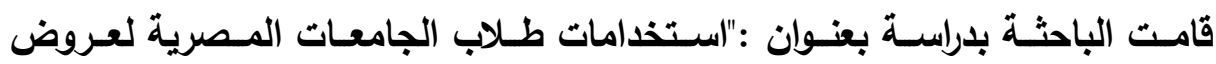

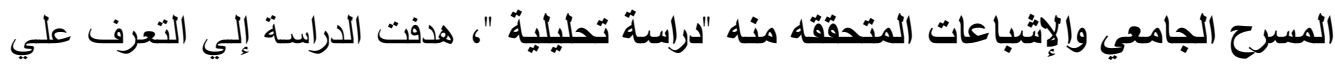

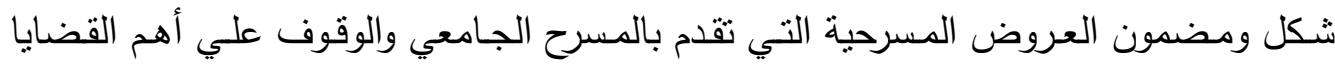

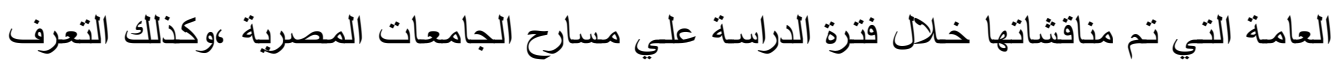

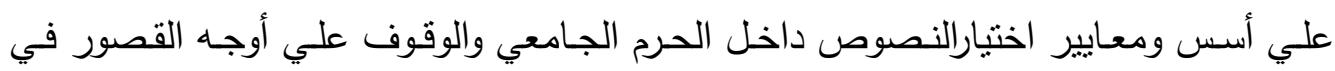

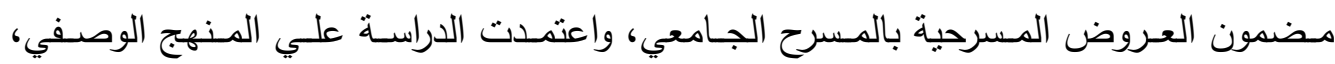

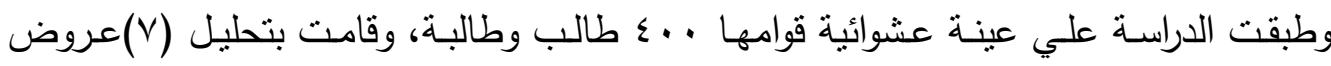

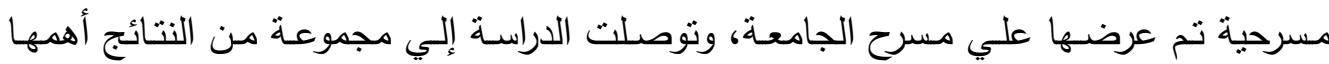

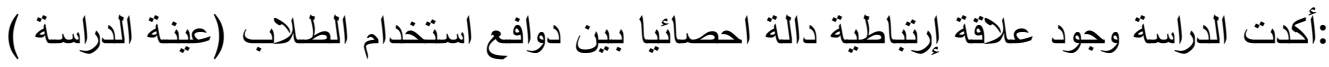

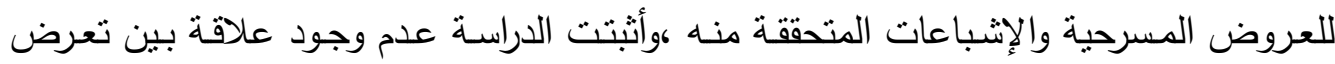

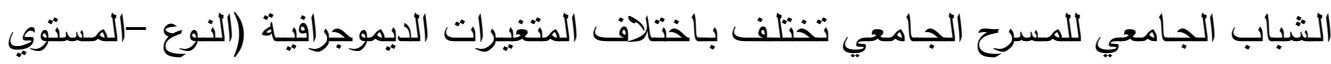

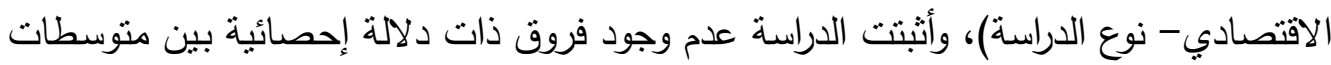

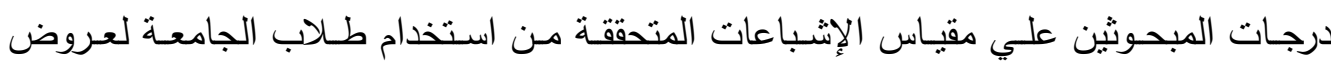
المسرح الجامعي وفقا (النوع ، المستوي الاجتماعي والاقتصادي).

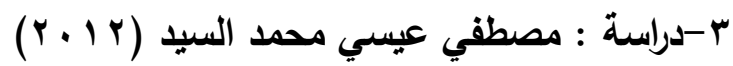

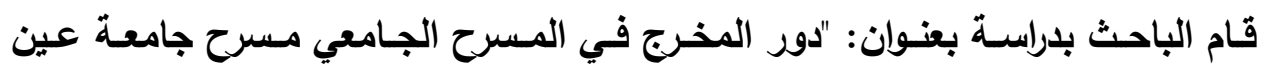

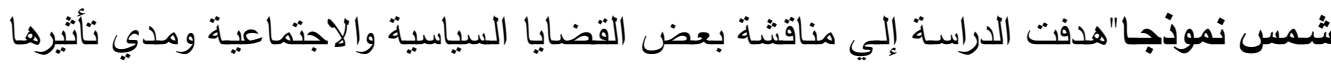

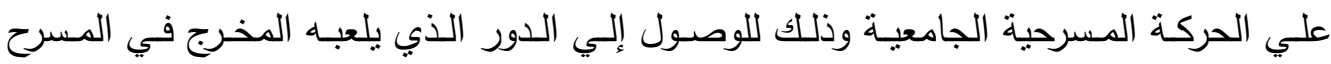

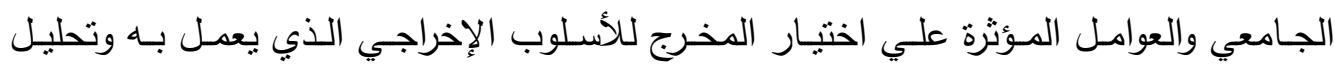
العروض الخاصة بالنموذج التطبيقي وهو جامعة عين شمس، ومن أهم القضايا التي تتاولتها

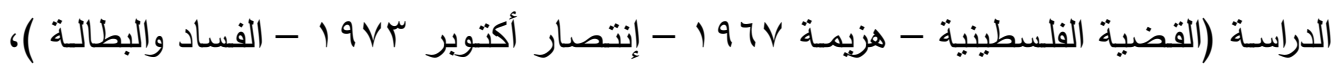


توصلت الدراسـة إلي مجموعـة من النتائج من أهمها : نأثنير المسرح الجامعي علي الحركة

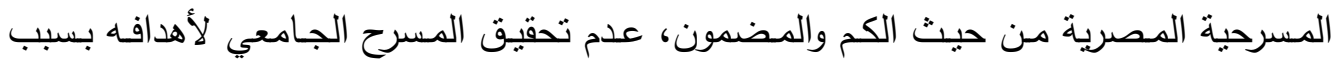

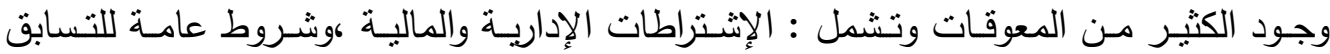

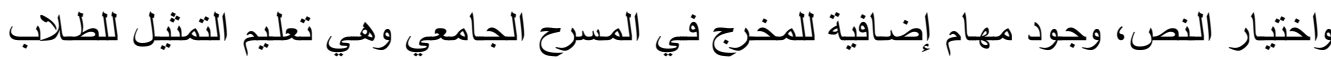

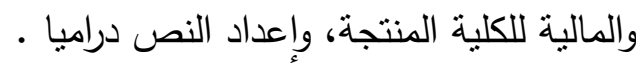

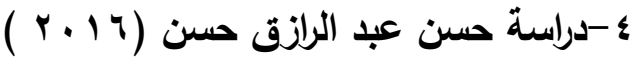

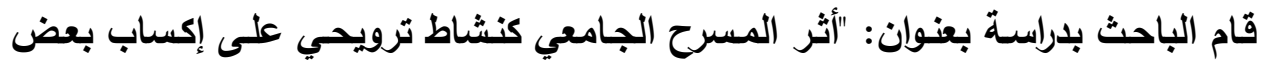

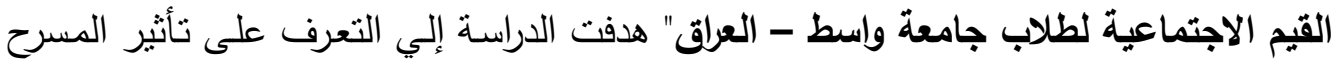

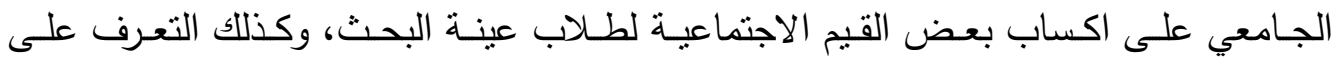

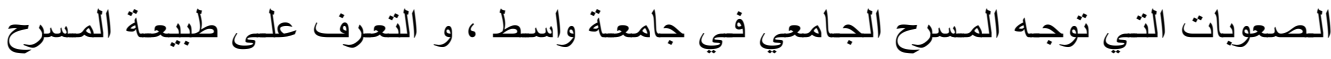

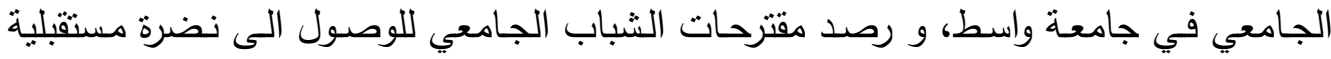

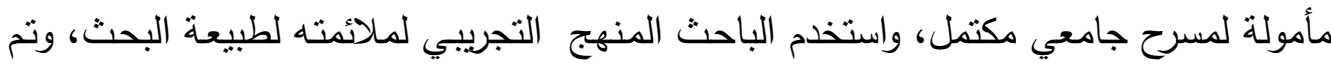

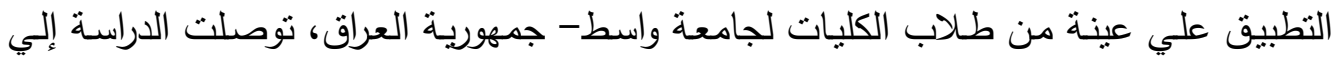

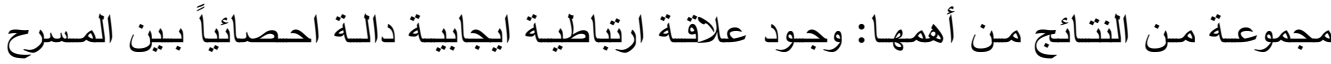

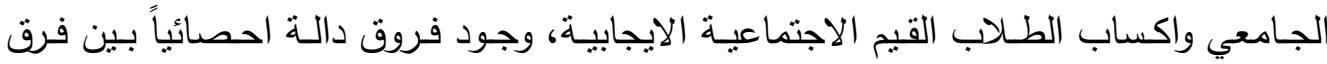

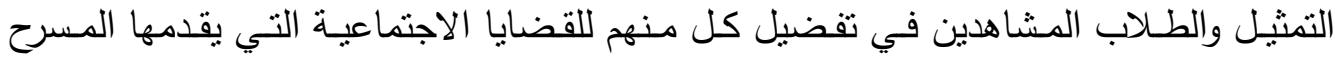
الجامعي ،وجود فروق دالة احصائياً بين الكليتين (الفنون الجميلة والتربية الرياضية لـائية ). المحور الثاني : دراسات تناولت سمات الثخصية لدي طلاب الجامعة:-

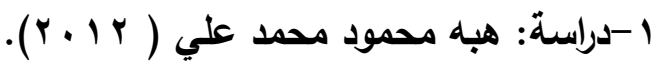

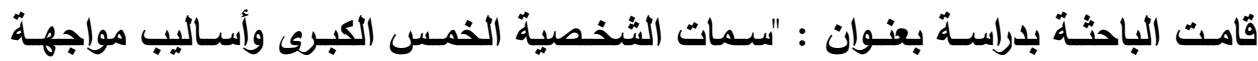

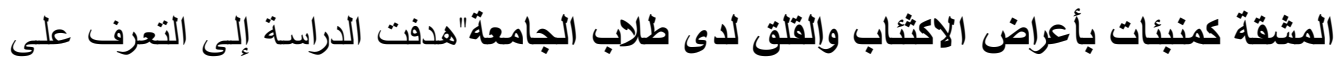

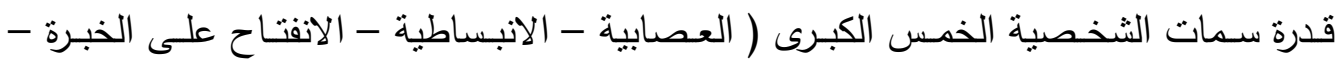

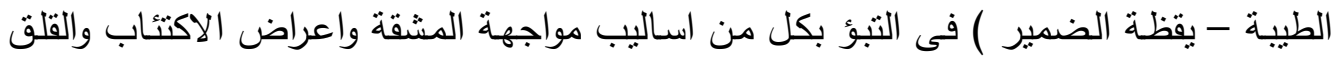

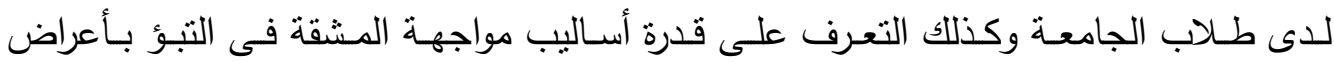
الاكتئـاب والقلق لدى طـلاب الجامعـة، وايضـا الكشف عن الفروق بين الجنسين من طـلاب

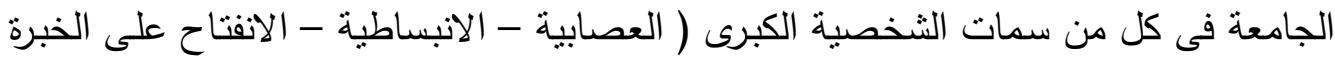

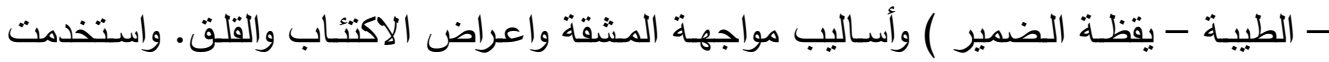

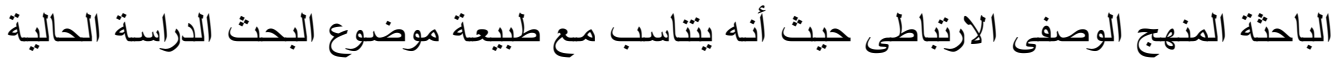

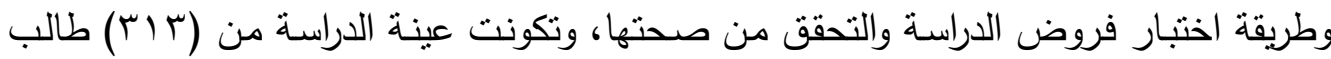

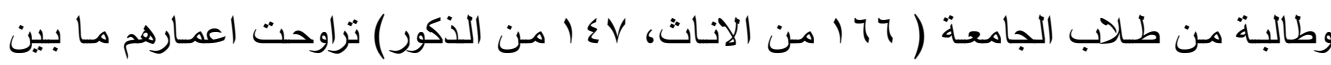




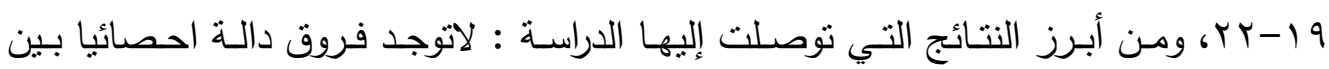

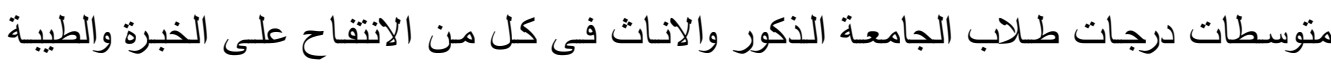

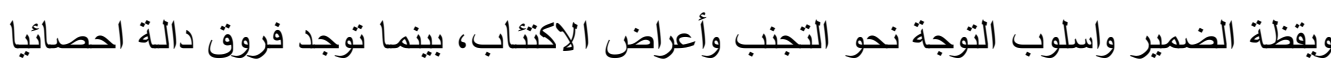

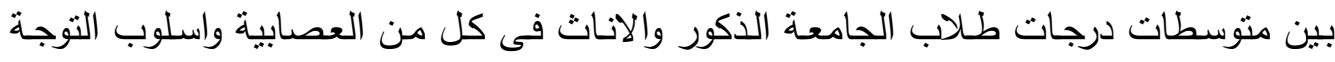

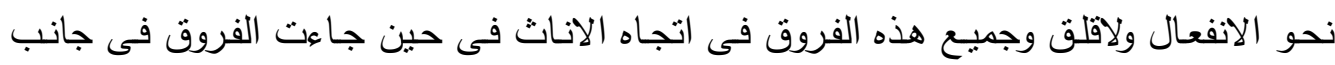
الذكور فى كل من الانبساطية واسلوب التوجة نحو الاداء.

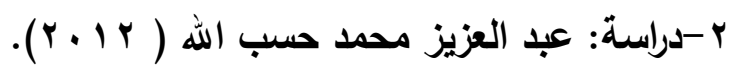

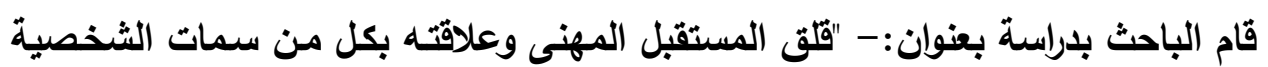

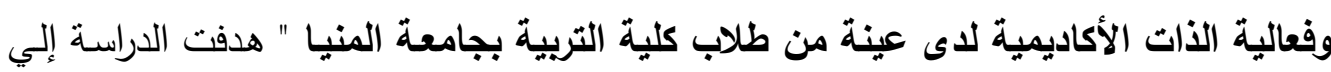

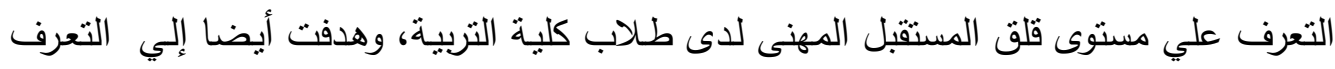

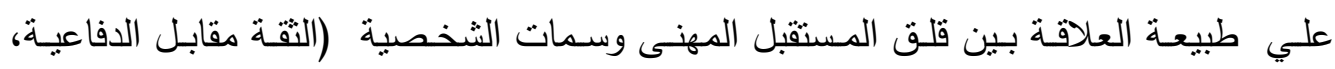
والتطابق الإجتماعى مقابل التمرد )، وطبقت هذه الدراسـة علي عينـة من طـلاب كلية التربيـة

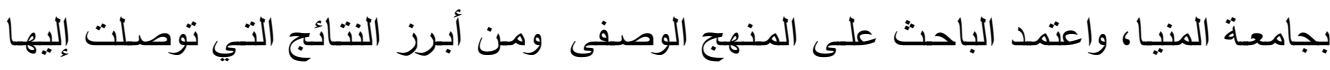

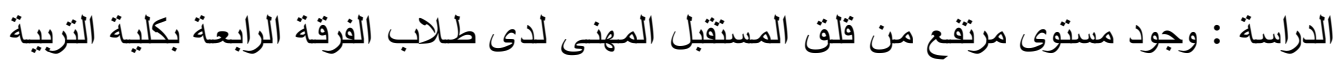

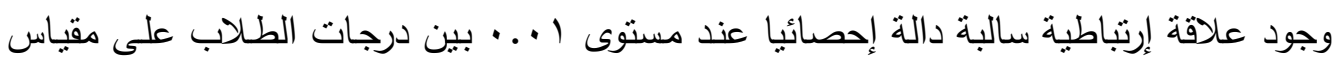

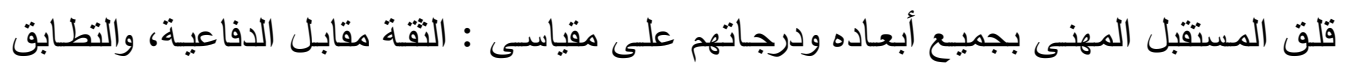
الإجتماعى مقابل التمرد.

المحور الثالث: دراسـات تناولت العروض المسرحية وعلاقتها بسمات الثخصية لدي طلاب

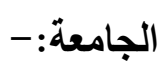

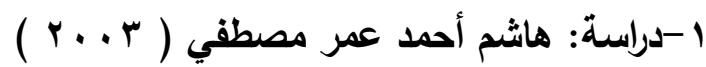

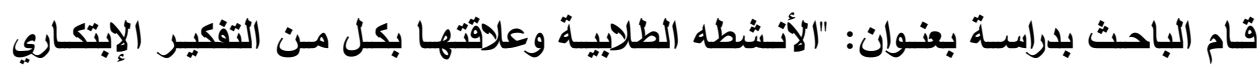

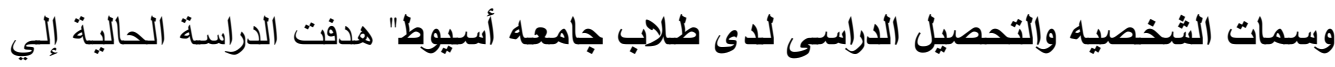
دراسـة الأنشطة الطلابيـة وعلاقتها بكل من التفكير الإبتكاري وسـمات الثخصية والتحصيل هديل

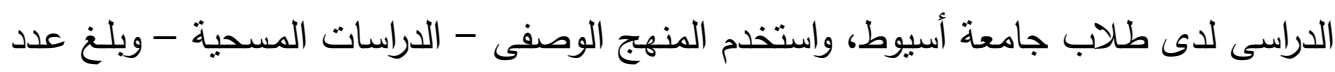

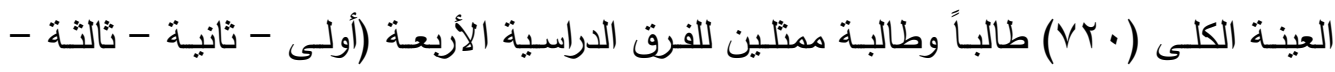
رابعة)، وكانت أدوات جمع البيانات - مقياس القدرة على التفكير الإبتكاري لسمات الثخصية. 
ومن أهم النتائج التي توصلت إليها الدراسة: ممارسة الأنشطة الطلابية تعمل على تتمية

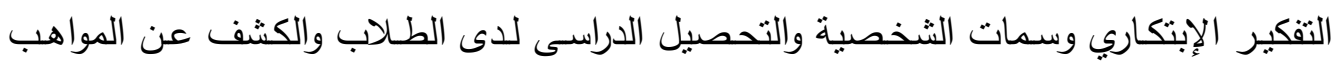

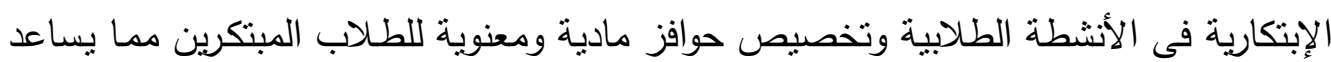

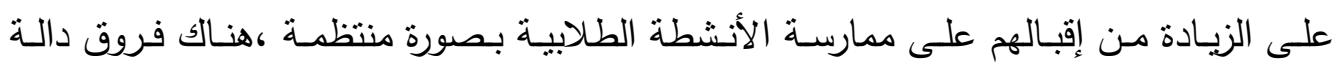
إحصائياً بين الطلاب الممارسين وغير الممارسين للأنشطة في القدرات الابتكاريـة (الطلاقة، المرونة، الأصالة، الحساسية للمشكلات، القدرة على التفكير الإبتكاري) لصالح الممارسين.

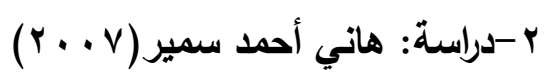

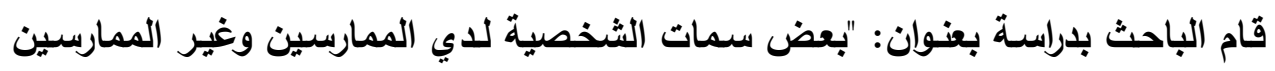

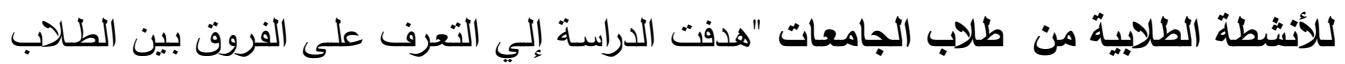

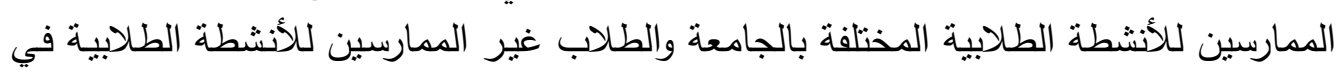

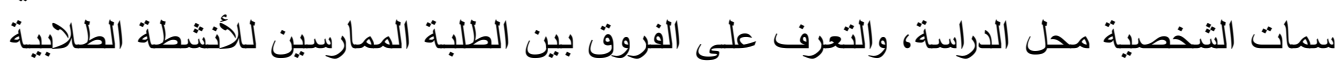

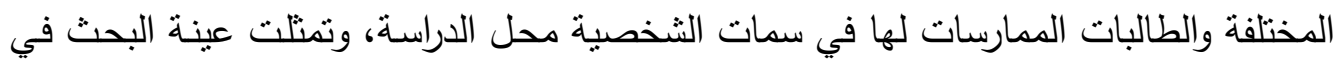

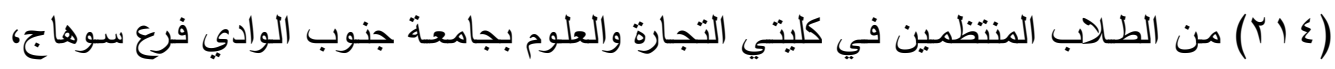

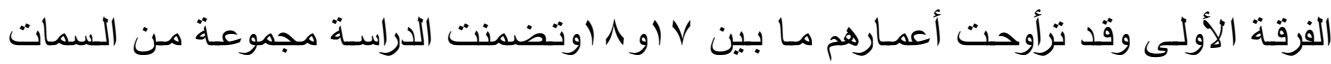

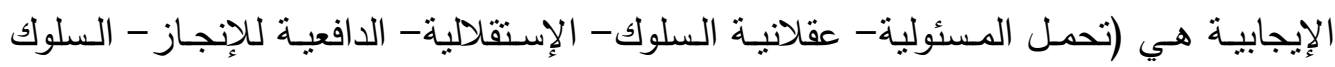

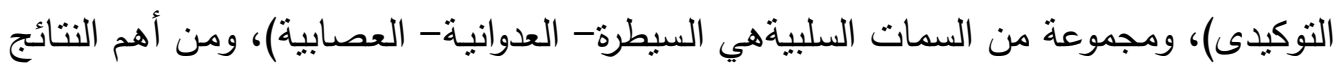

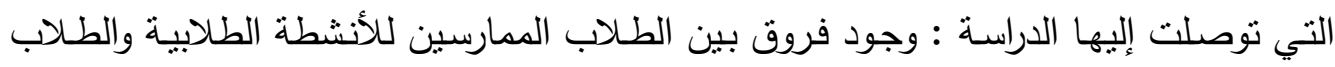

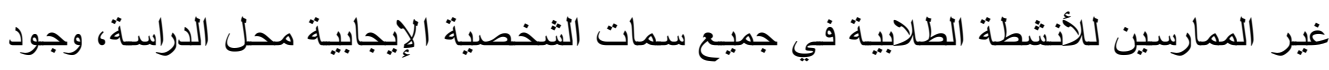

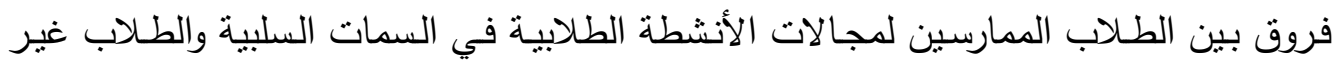

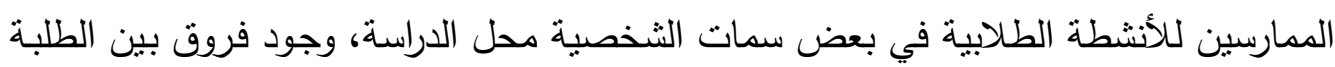

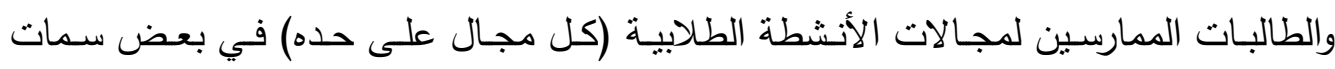
الشخصية محل الدراسة.

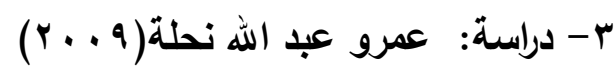

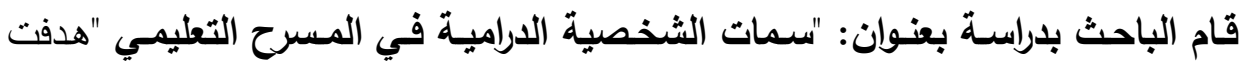

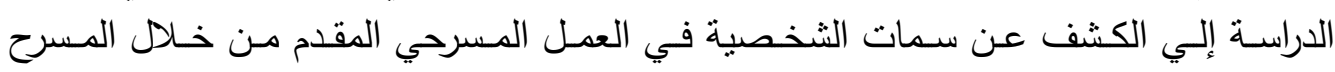

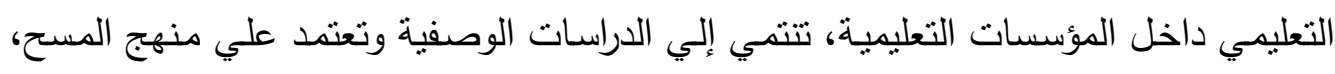

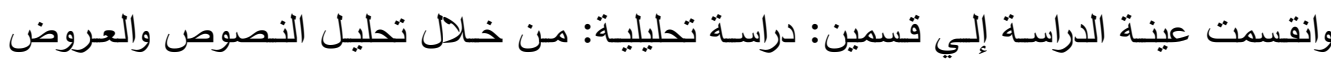

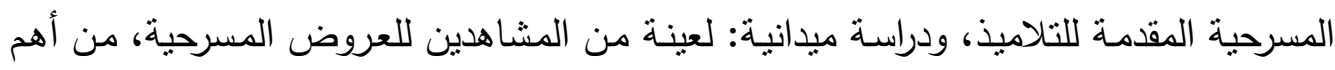

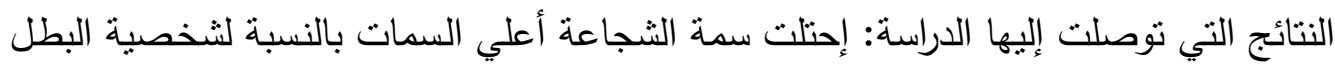

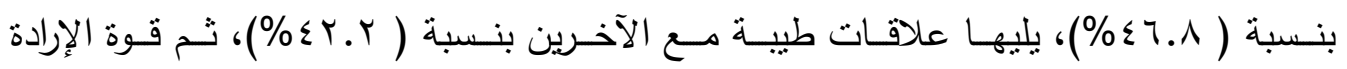




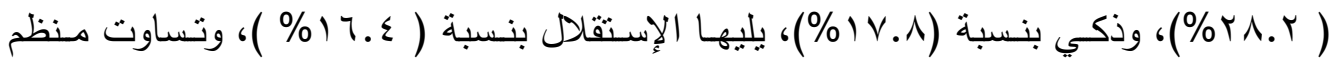

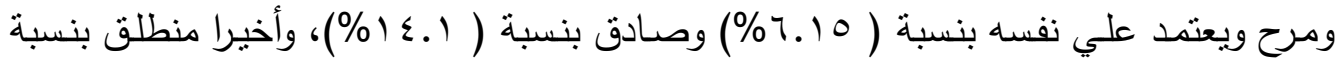

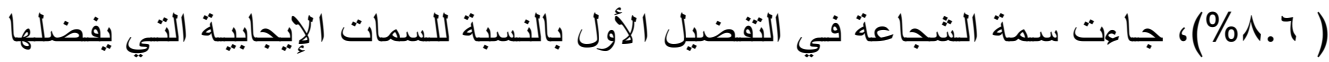

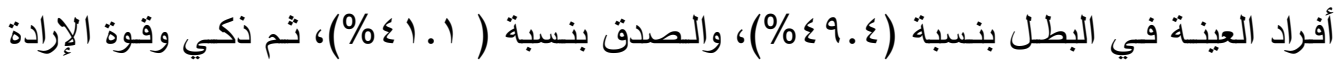

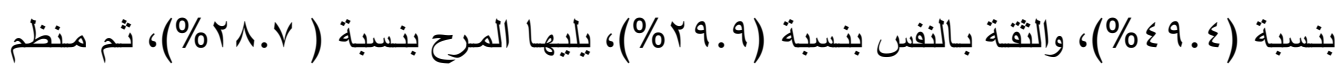

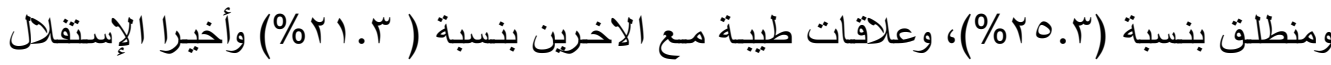

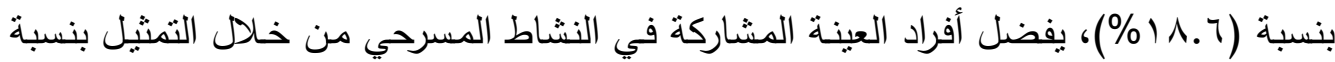

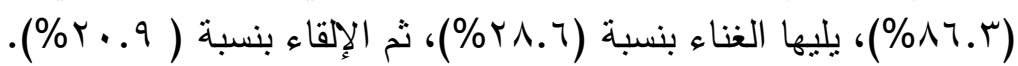
الاستفادة من الاراسات السابقة:

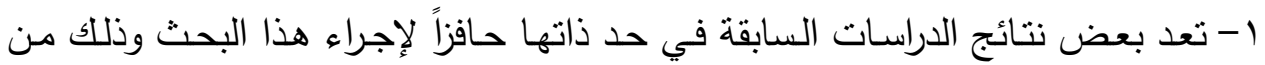
خلال الوقوف على أحدث النتائج التي توصل إليهابها الباحثين السابقين.

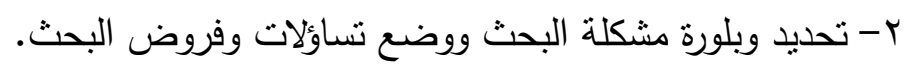

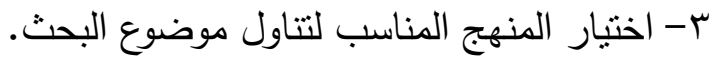

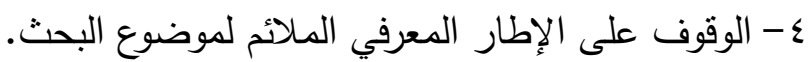

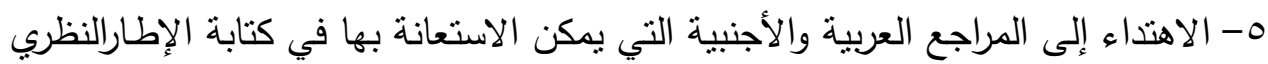

$$
\text { فروض البحث:. للبحث. }
$$

الفـرض الأول : توجد فروق دالـة إحصائياً بـين منوسط درجـات الطـلاب في القيـاس القبلي

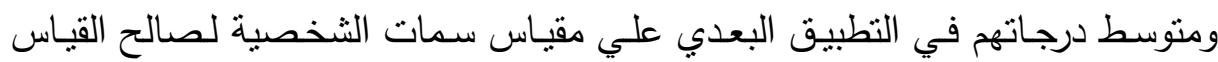

$$
\text { البعدي. }
$$

الفرض الثاني : توجد فروق دالة إحصائياً بين منوسط درجات الذكور ومتوسط درجات الإناث

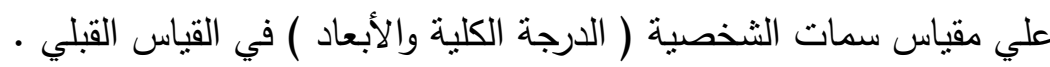

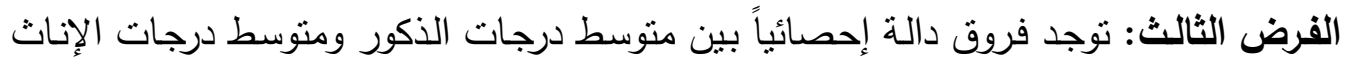

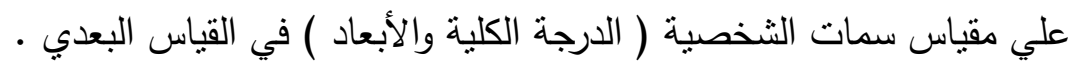

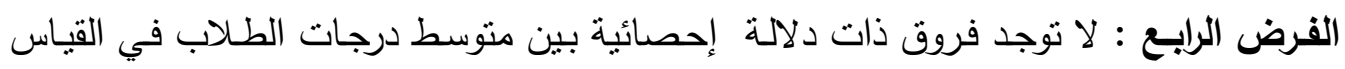

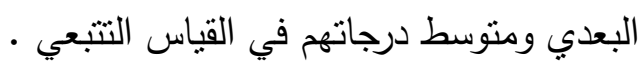

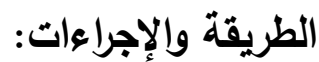

تمثلت عينة البحث في (r) طالب من طلاب الفرقة الثالثة بقسم الإعلام التربوي (مسرح ) بكلية التربية النوعية جامعة المنوفية . 
تم جمع بيانات البحث الحالي من خلال:

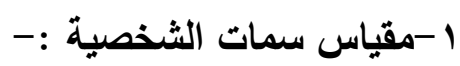

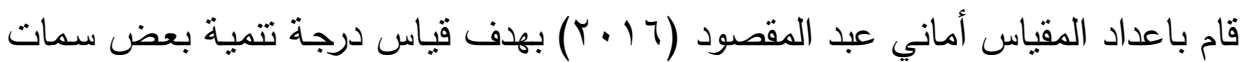

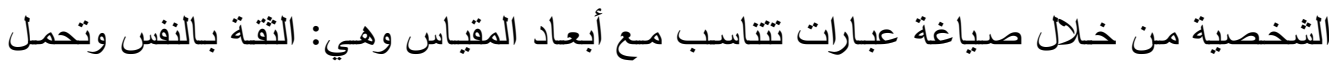

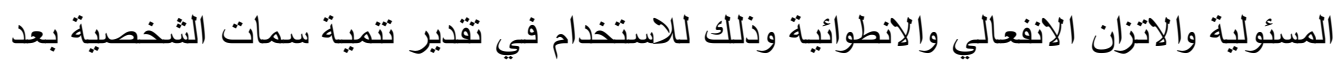

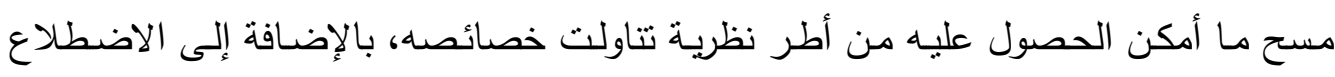
على عدد من المقاييس الأجنبية في المجال.

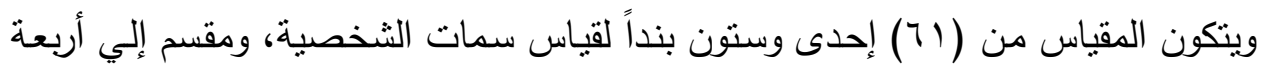

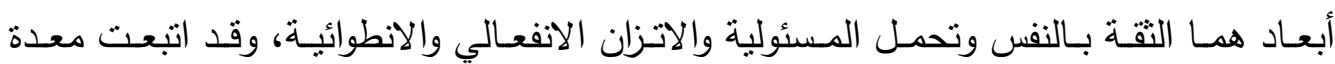

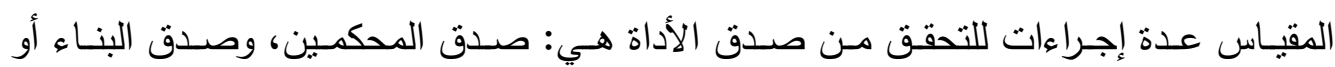
التكوين.

وقد نم حساب الثبات بطريقتين هما: أ- طريقة إعادة التطبيق ب- طريقة ألفا كرونباخ

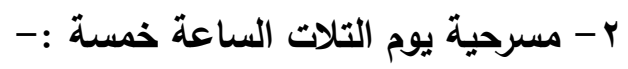

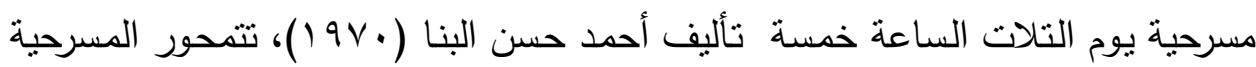

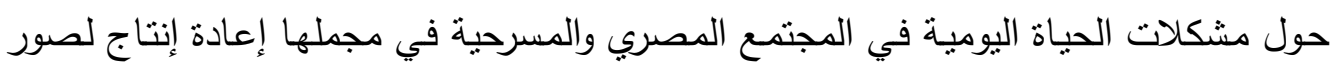

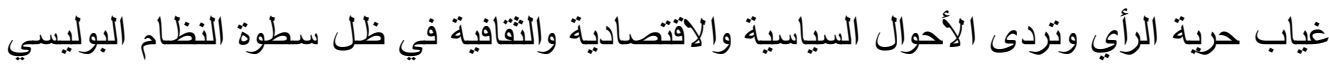

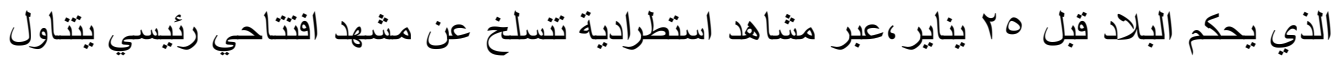

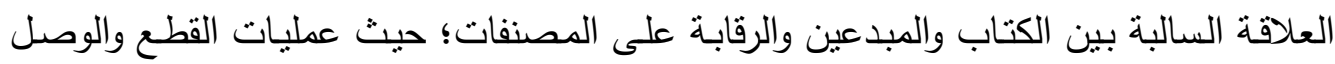

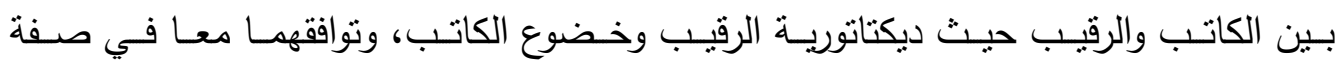

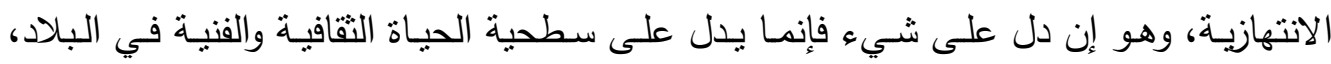
وتتضمن المسرحية بعض سمات الثخصية الايجابية مثل سمة تحمل المسئولية حيث تظهر

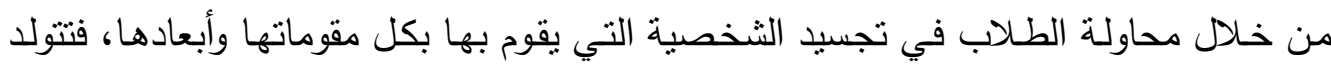

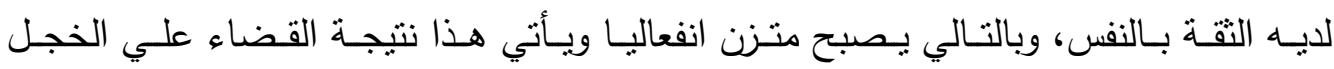
والانطوائية لديه

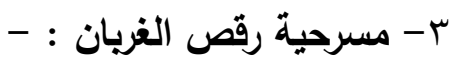

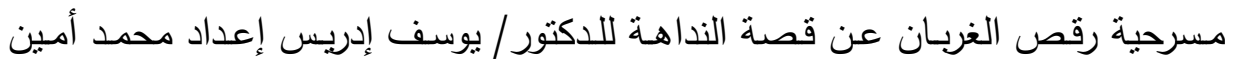

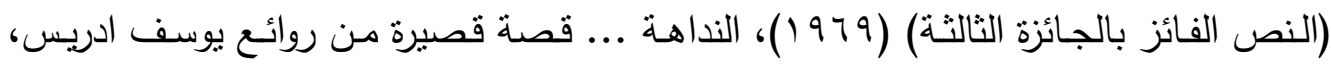

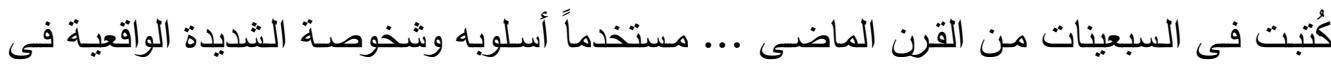

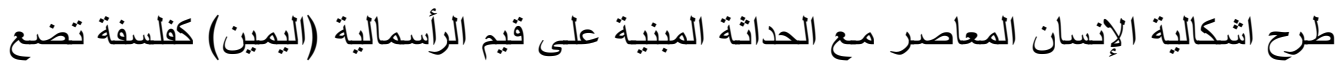


المادة هدفا للإنسان فى مقابل الفلسفات الاشتراكية التى تتادى بواقع أكثر إنسانية، وتتضمن هذه

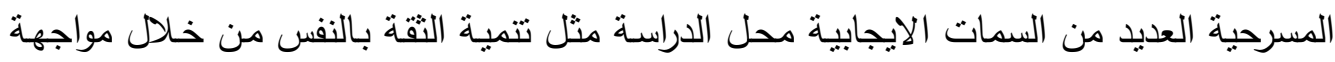

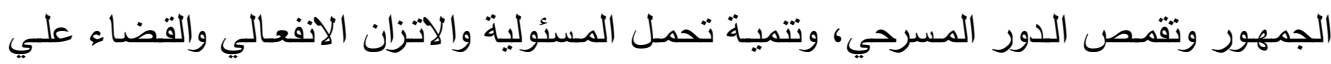

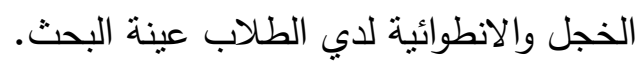
ع -مسرحية يا بهية وخبريني :-

مسرحية يابهية وخبريني تأليف نجيب سرور (9TV (1)، تعتمد هذه المسرحية على موّال

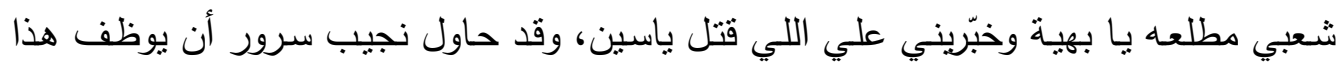

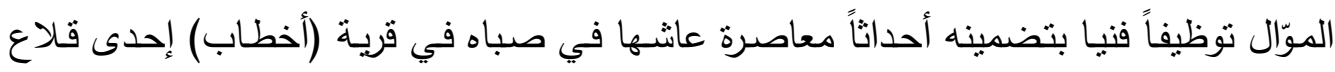

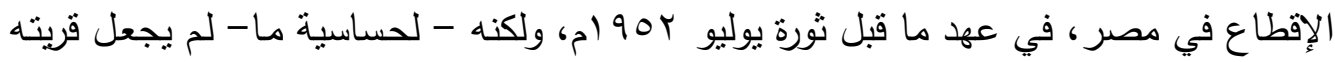

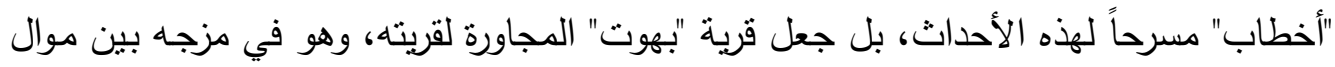

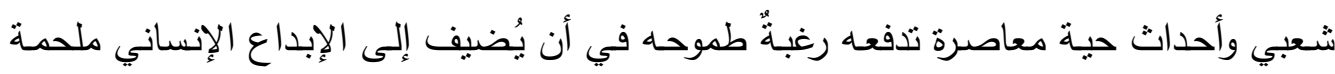

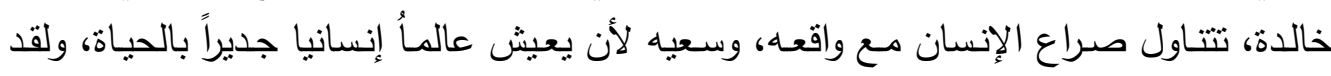

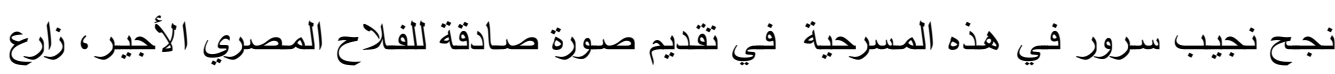

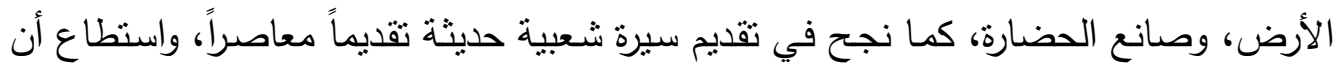

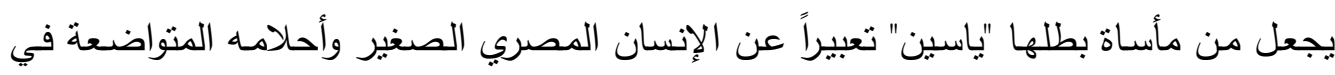

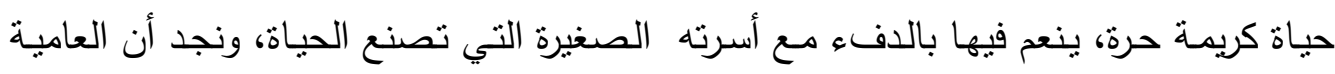

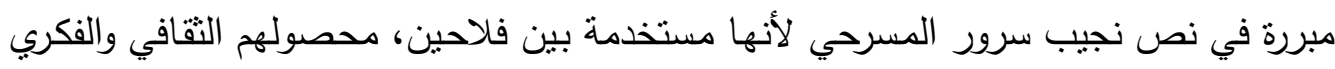

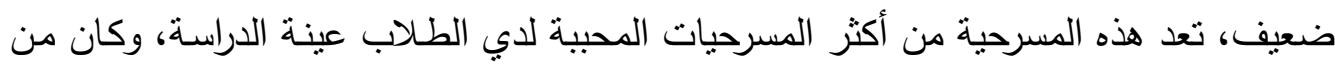

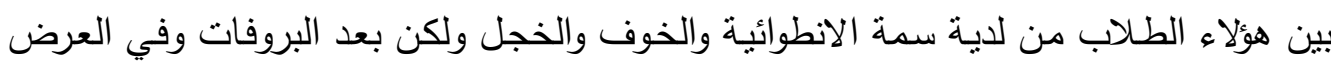

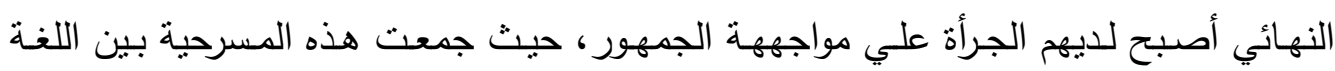

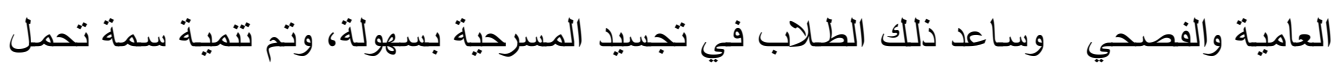

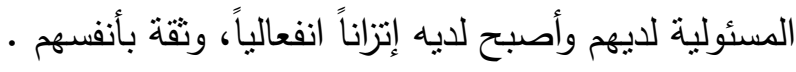

نتائج البحث ومناقشتها:أولاً: بالنسبة للقرض الأول ومنافئوا: الأول ينص الفرض الأول علي أنه: توجد فروق دالة إحصائياً بين متوسط درجات الطلاب في

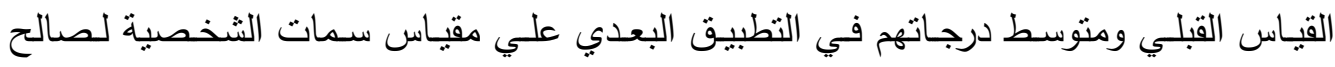
القياس البعدي. وللتحقق من صحة هذا الفرض تم استخدام اختبار "ت" ( T.test) وذلك لحساب دلالـة الفروق بين منوسطات درجات المجموعتين التجريبية قبلي والتجريبية بعدي علي مقياس سمات فلثرات 
ثم من خلال التمثيل البياني تم مقارنة سمات الثخصية لدي المجموعتين (التجريبية قبلي والتجريبية بعدي ) والجدول رقم ( ) يوضح ذللك.

جدول (1)

الفروق بين متوسطات درجات الطلاب في القياس القبلي ومتوسطات درجاتهم في القياس البعدي علي

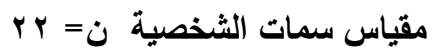

\begin{tabular}{|c|c|c|c|c|c|c|c|c|}
\hline \multirow{2}{*}{ الدلالة } & \multirow{2}{*}{ قيمة ت } & \multicolumn{3}{|c|}{ تجريبية بعدي } & \multicolumn{3}{|c|}{ تجريبية قبلي } & \multirow{2}{*}{ سمات الشخصية } \\
\hline & & $\varepsilon$ & r & ن & $\varepsilon$ & 5 & ن & \\
\hline مستوي الة عند . . & Y0.V07 & 1.194 & 51.91 & YY & $1 . v \leqslant r$ & $r \cdot . \cdot q$ & Yr & الثقة بالنفس \\
\hline مستوي الة عند & $19.57 Y$ & 1.991 & $r . .09$ & rr & Y.YI. & 19.17 & rr & تحمل المسئولية \\
\hline مستوي الة عند & 17.211 & 1.040 & $r \leqslant .00$ & rr & $1 . V \times 1$ & $17 . V V$ & YY & الاثران الانفعالي \\
\hline مستوي الة عند . & Y). $\leqslant 9 \leqslant$ & r...q & rT.rY & YY & $1 . r 09$ & IN.rY & Yr & الانطوائية \\
\hline دالة عندي ا ـ ـ & $\begin{array}{c}\varepsilon \cdot .199 \\
9\end{array}$ & Y.70. & 114.0 & YY & $\varepsilon .7 \vee \wedge$ & $V \leqslant .9$ & YY & الدرجة|الكلية للمقياس \\
\hline
\end{tabular}

يتضح من الجدول (1 ) أنه توجد فروق ذات دلالة إحصائية بين القياس القبلي والبعدي

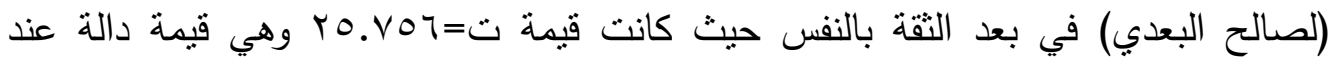

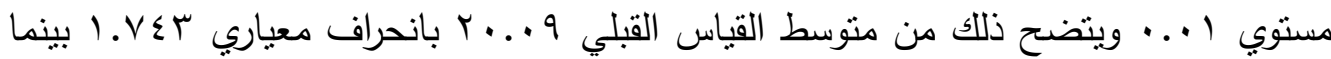

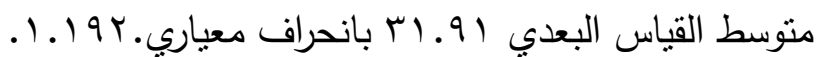

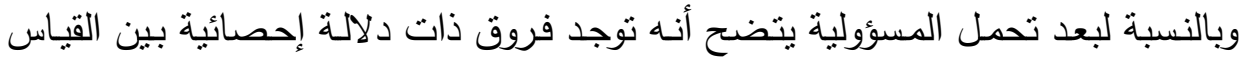

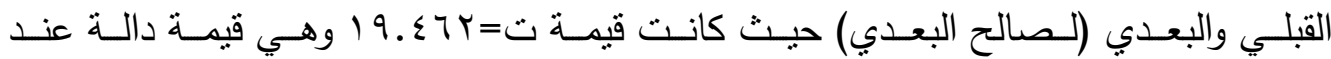

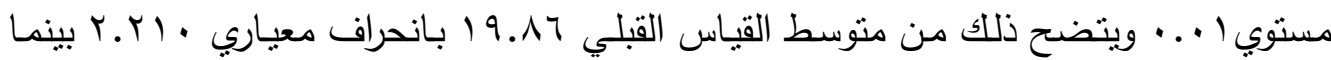

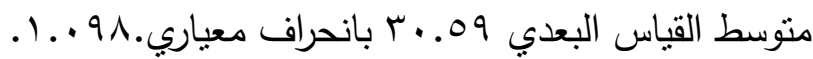

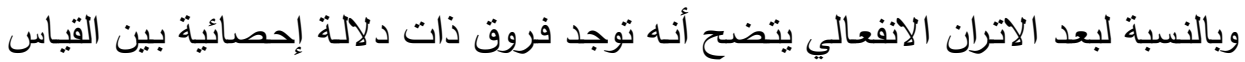

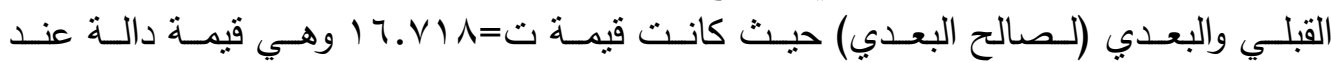

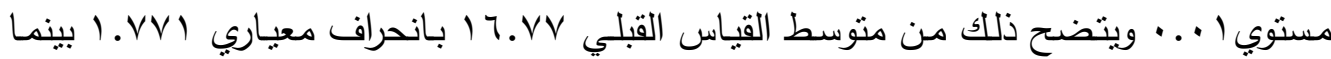

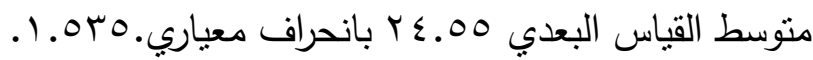


وبالنسبة لبعد الانطوائية يتضح أنه نوجد فروق ذات دلالة إحصائية بين القياس القبلي

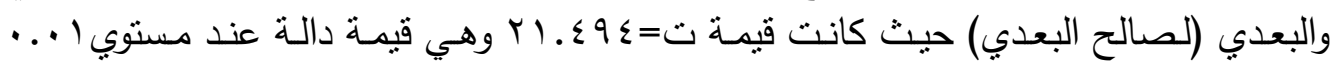

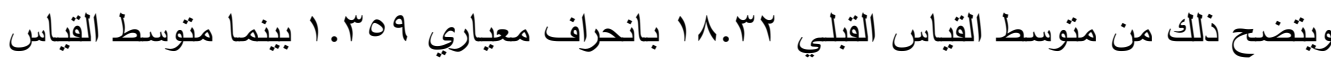

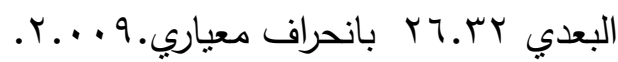

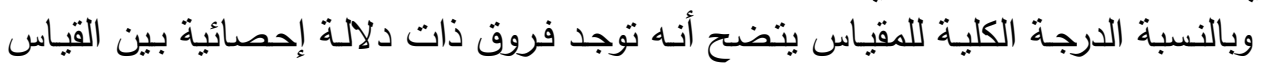

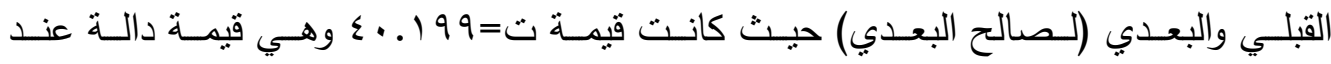

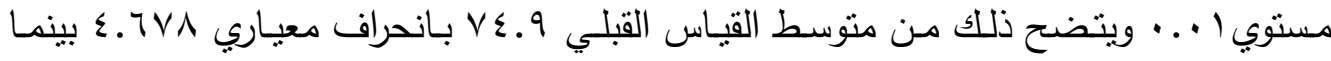

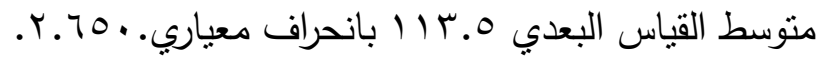
وتدل هذه النتائج علي تحسن مستوي سمات الثخصية لتحية لدي أفراد المجموعة التجريبية

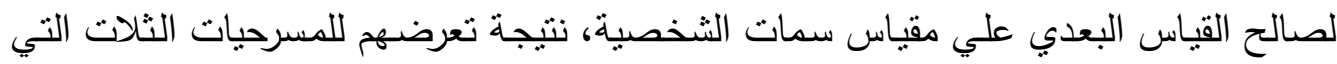

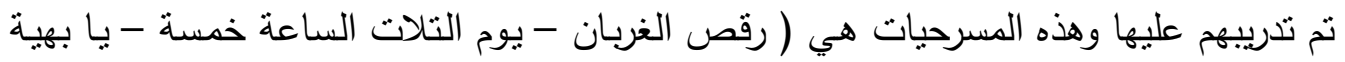

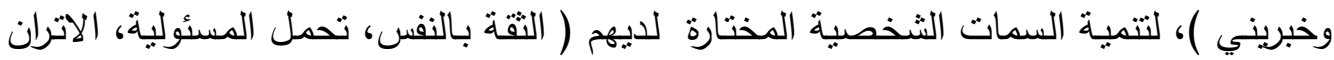

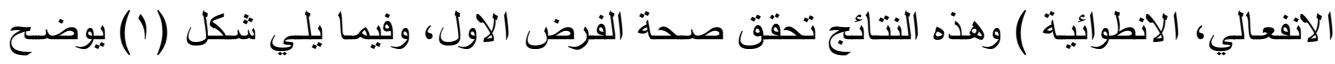
ذلك.

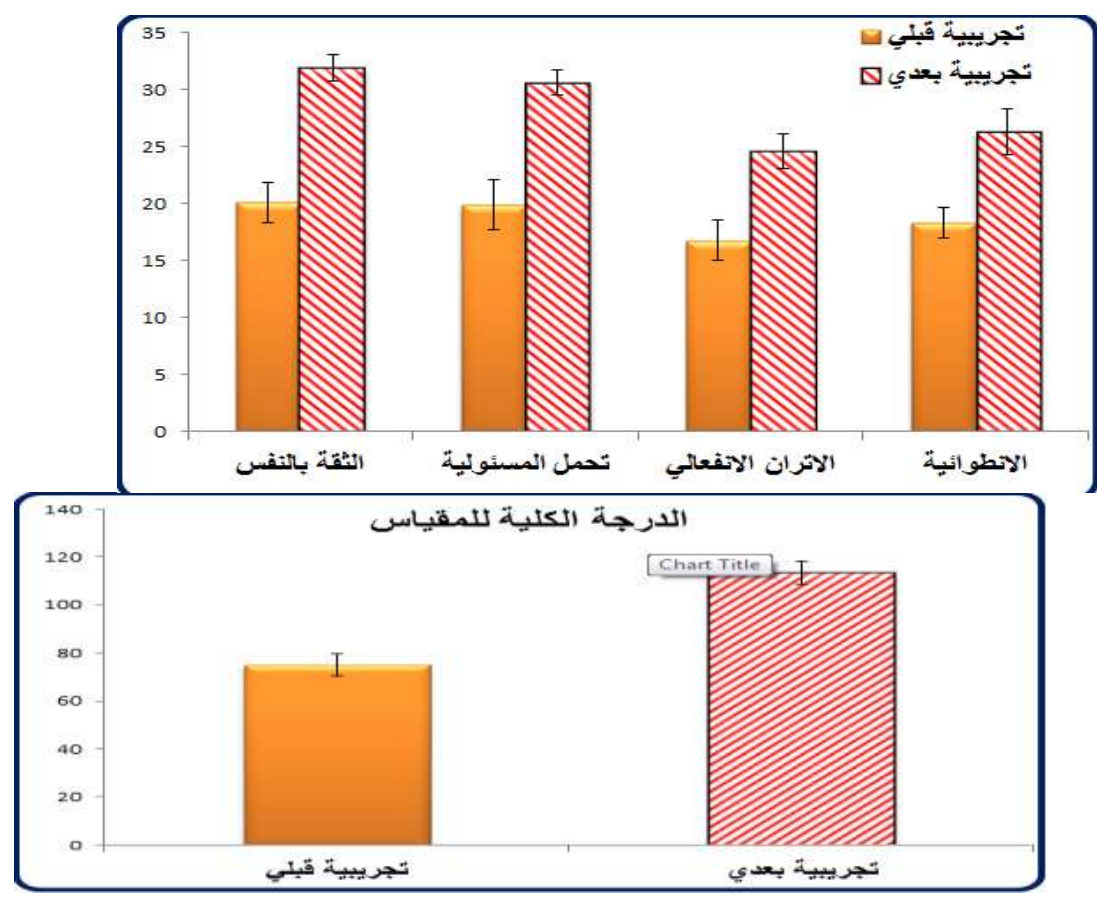

شكل (1)

التمثيل البياني لمتوسطات درجات الطلاب في القياس القبلي ومتوسطات درجاتهم في القياس البعدي علي مقياس سمات الثخصية ( الدرجة الكلية والأبعاد) . 
يتضح أيضا من الشكل (1) أن متوسطات درجات أفراد المجموعة التجريبية قبلي أقل من متوسطات درجات أفراد المجموعة التجريبية بعدي علي مقياس سمات الثخصية ( الدرجة

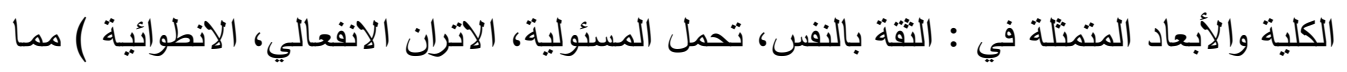

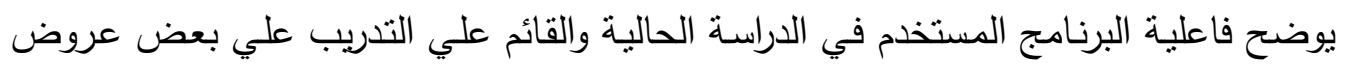

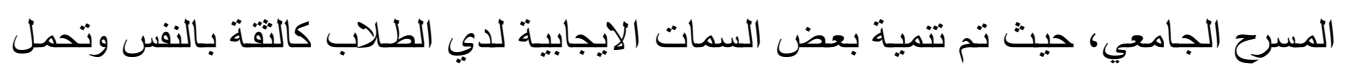
المسئولية والاتزان الانفعالي وتم القضاء علي بعض السمات السلبية مثل الخجل والانطوائية وكان هذا هو الهدف من التدريب علي تلك العروض المسرحية .

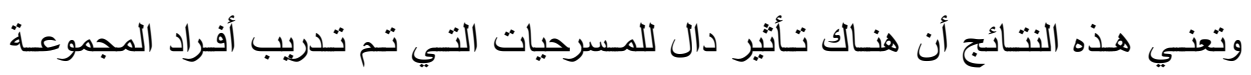
التجريبية عليها لصالح القياس البعدي، حيث أن متوسطات الدرجات التي حصل عليها أفراد

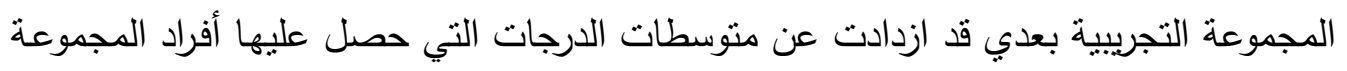

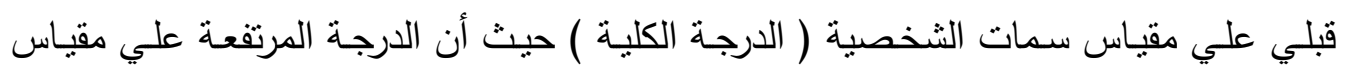
سمات الثخصية تثير إلي تتمية السمات الثخصية ( موضع البحث ).

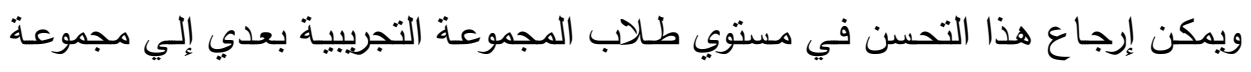

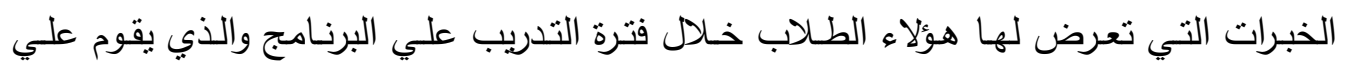
التدريب علي بعض عروض المسرح الجامعي ، والتي عملت علي إتاحة خبرات فعلية لتمثيل

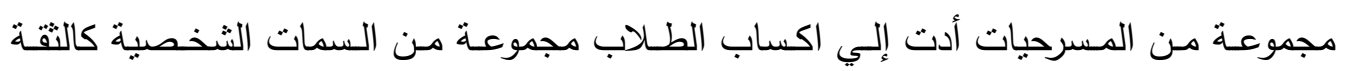

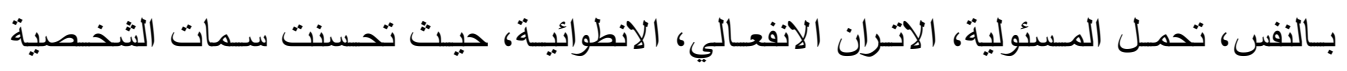

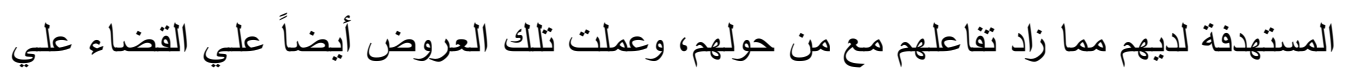

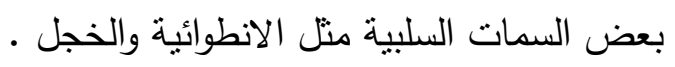

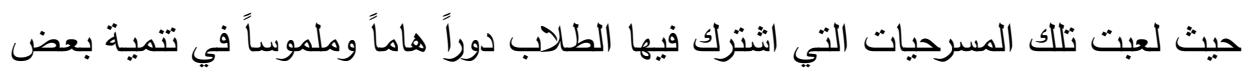

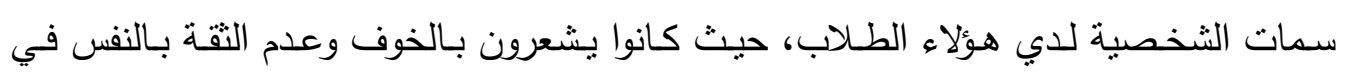
البروفات الأولي ولكن مع التدربب والبروفات أصبح لديهم ثقة بأنفسهم، واتضح ذلاء بلك من خلاد

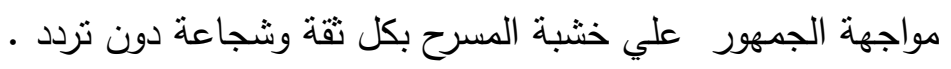

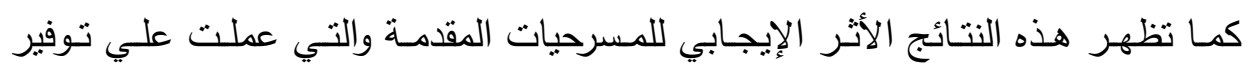

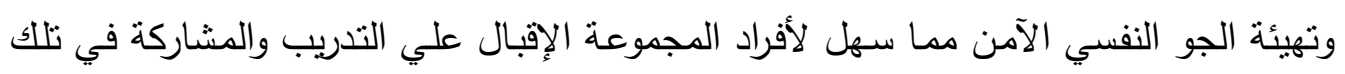
العروض، كما عمل علي زيادة قدرتهم علي التعاون وحب العمل الجماعي وتحمل المسئولية معاً كفريق ويد واحدة. 
كما أتاح اشتراك الطلاب في هذه العروض المسرحية إلي معايشة مواقف حياتية تدور

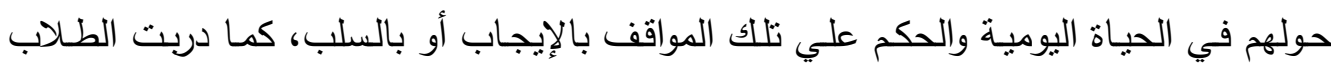
علي التحكم في انفعالاتهم، كما أناحت الفرصة للطالب ليشعر بالآخرين في المواقف المختلفة، وبأهمية أن يلتزم بحدوده ويحترم الآخرين ويتدرب علي تحمل المسئولية والتقة بالنفس من خلال ما يؤديه من أدوار، كما عملت أيضاً علي اثثباع حاجات الطلاب المختلفة كالحاجة إلي الحب الب والتعـاون، والتعرف علي مـواطن القوة والضعف في شخصياتهم، كمـا قدمت فرصـة للتعبير والتففيس الانفعالي عن ما يوجد بداخلهم من طاقات مكبوتة وساعدت علي إخراج تلك الطاقات في صورة إيجابية. وتتفق هذه الروئية مع ما أثنار إليه صـلاح عقل ( . . ب) أن "التمثل يعمل علي الكثف عن المشاعر السلبية فيسقطها الممثل علي شخصيات الدور التمثيلي وينفس عن انفعالاته ويعبر عن اتجاهاته وصراعته ودوافعه"، ويعمل تقصص الطالب دور معين إلي التنفيس الانفعالي والذي يساعده علي تفريخ الشحنات السلبية واخراخ الخبرات المتراكمة المخزونة التي تسبب التوترات مما يؤدي إلي تطهير الذات والتزان الانفعالي ويتفق هذا مع دراسة نبيل سفيان $\cdot(r \cdot \varepsilon)$

وتتفق الدراسـة كلياً مـع نتائج الدراسـات التي استخدمت المسرح بكل فنياته كأداة أساسية لخفض المشكلات السلوكية التي قد يعاني منها بعض الطلاب ( أمنة زقوت، . . . ب ؛ منال

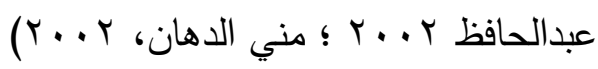
ثانياً بالنسبة للفرض الثاني : أنافي

ينص الفرض الثاني علي أنه "توجد فروق دالـة إحصائياً بين متوسط درجات الذكور

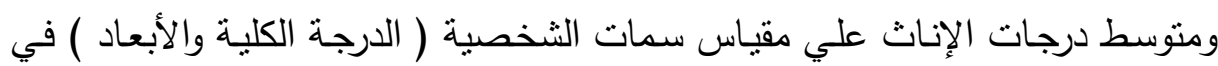

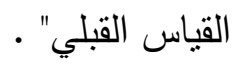
وللتحقق من صحة هذا الفرض تم استخدام اختبار (T.test) وذلك لحساب دلالـة الفروق بين متوسطات درجات الذكور ومتوسطات درجات الإناث علي مقياس سمات الثخصية والجدول رقم (r) يوضح ذلك . 


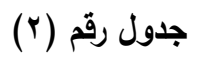

الفروق بين متوسطات درجات الأكور ومتوسطات درجات الإناث علي مقياس سمات الثخصية

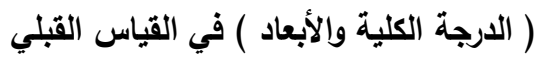

\begin{tabular}{|c|c|c|c|c|c|c|c|c|}
\hline \multirow{2}{*}{ الدلالة } & \multirow{2}{*}{ قيمة ت } & \multicolumn{3}{|c|}{ إناث قبلي } & \multicolumn{3}{|c|}{ ذكور قبلي } & \multirow{2}{*}{ سمات } \\
\hline & & $\varepsilon$ & 5 & ن & $\varepsilon$ & s & ن & \\
\hline غيردالة & $.9 \leqslant 0$ & I.VAI & $r . . T 4$ & $1 \varepsilon$ & 1.710 & 19.74 & $\wedge$ & الثقة بالنفس \\
\hline غبردالة & $.0 V \varepsilon$ & T.T.Y & $r \ldots v$ & $1 \varepsilon$ & r.ITA & 19.0. & $\wedge$ & تحمل المسئولية \\
\hline دالةعند مستوي & r.99Y & $1.00 \mathrm{~V}$ & IV.o. & $1 \varepsilon$ & $1 . \varepsilon 1 \leqslant$ & 10.0. & $\wedge$ & الالفعالي \\
\hline غيردالة & 1.941 & $1 . .79$ & $11.1 \mathrm{~V}$ & $1 \varepsilon$ & 1.091 & IV.Tr & $\wedge$ & الانطوائية \\
\hline مستوي 0 ـ. & Y.1199 & $T .0 \leqslant 7$ & $V 4 . \varepsilon r$ & $1 \varepsilon$ & $0 . \leqslant \leqslant 0$ & VT.YO & $\wedge$ & اللارجة الكلية \\
\hline
\end{tabular}

يتضح من الجدول السابق ( r (r) عدم وجود فروق دالة احصائياً بين متوسطات درجات الطلاب الذكور والاناث في القياس القبلي لمقياس سمات الثخصية المتمتلة في الثقة بالنفس،

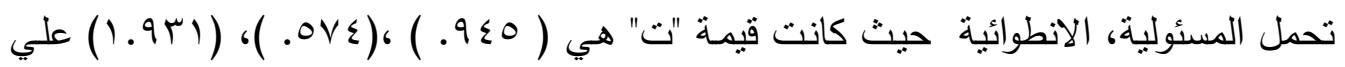
في حين وجدت فروق دالة احصائياً بين متوسطات درجات الطلاب الذكور والاناث في القياس القبلي لمقياس سمات الثخصية بالنسبة لبعد الاتزان الانفعالي، المقياس ككل، حيث

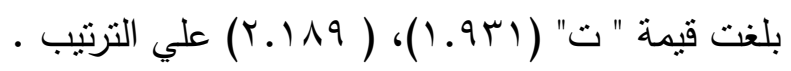

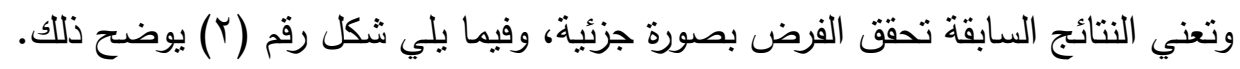




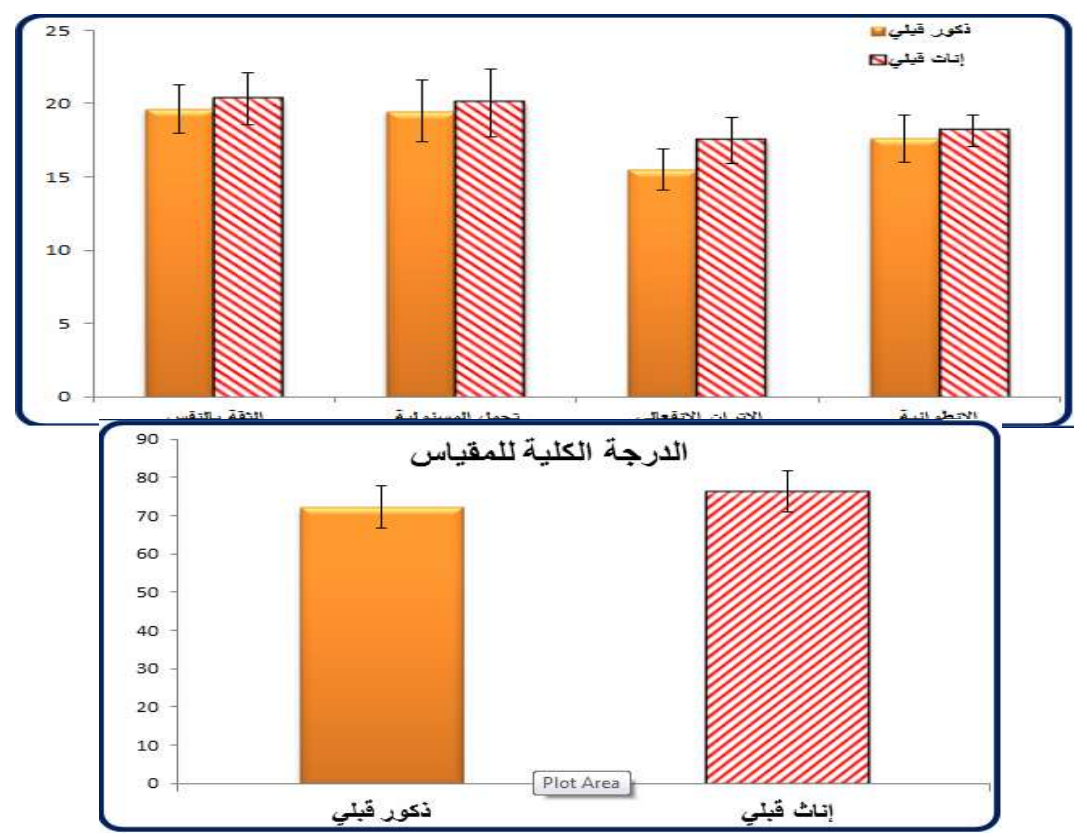

شكل (r)

التمثيل البياني لمنتسطات درجات الذكور ومتوسطات درجات الإناث علي مقياس سمات الثخصية ( الدرجة الكلية والأبعاد ) في القياس القبلي.

يتضح من الجدول السابق (Y) أن متوسطات درجات الذكور ومنوسطات درجات الإناث

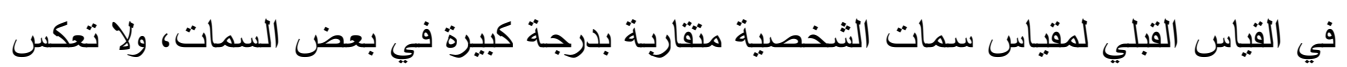
إلا فروقاً طفيفة، وغير دالة إحصائياً، وذلك في سمة الثقة بالنفس، تحمل المسئولية، والانطوائية مما يدل علي عدم وجود فروق بين الذكور والإناث في هذه السمات، أمسا في سمة الاتران

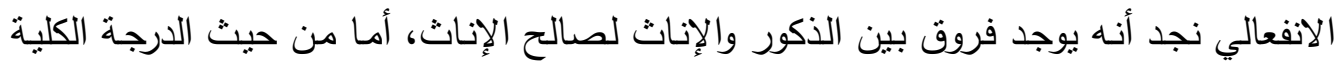

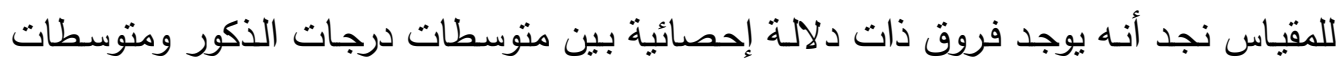

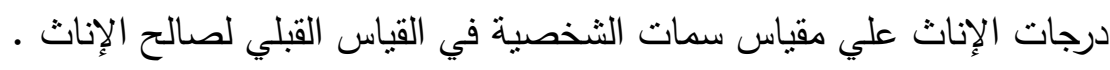
ثالثاً بالنسبة للفرض الثالث:

ينص الفرض الثالث علي أنه " توجد فروق دالة إحصائياً بين متوسطات درجات الذكور

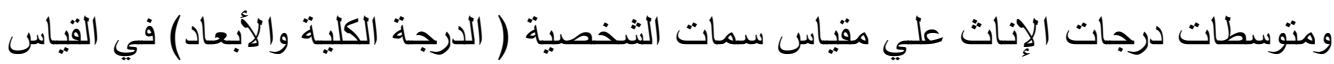
البعدي. وللتحقق من صحة هذا الفرض تم استخدام اختبار "ت" ( T.test) وذلك لحساب دلالة الفروق بين متوسطات درجات الذكور ومتوسطات درجات الإناث علي مقياس سمات الثخصية

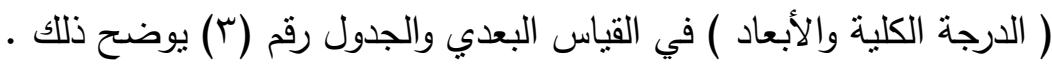


جدول رقم (r)

الفروق بين منوسطات درجات الذكور ومنوسطات درجات الإناث علي مقياس سمات

\begin{tabular}{|c|c|c|c|c|c|c|c|c|}
\hline \multirow{2}{*}{ الدلالة } & \multirow{2}{*}{ قيمة ت } & \multicolumn{3}{|c|}{ إناث بعدي } & \multicolumn{3}{|c|}{ ذكور بعدي } & \multirow{2}{*}{ سمات الثخصية } \\
\hline & & $\varepsilon$ & ? & ن & $\varepsilon$ & s & ن ن & \\
\hline غيردالة & . $\leqslant 7 \leqslant$ &.$\vee \wedge \varepsilon$ & rr... & $1 \leqslant$ & 1.vor & M.Vo & $\wedge$ & الثقة بالنفس \\
\hline غيردالة & l.r &.$\Lambda \cdot r$ & $r . . v q$ & $1 \leqslant$ & 1.201 & $r . .1 r$ & $\wedge$ & تحمل المسئولية \\
\hline غيردالة & $.9 v$. & 1.\&Y & $r \leq . V q$ & $1 \leqslant$ & I.VYV & rE.IT & $\wedge$ & الاتزان الانفعالي \\
\hline غيردالة & $1 . . . r$ & r.OYT & Y & $1 \leqslant$ & $1.9 \lambda r$ & ro.vo & $\wedge$ & الانطوائية \\
\hline 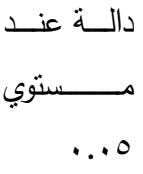 & r.70V & $r . \Sigma T \Lambda$ & דצ. & 1\{ & r.rvo & 111.20 & $\wedge$ & للمقياس \\
\hline
\end{tabular}

يتضح من الجدول السابق (r) عدم وجود فروق دالة احصائباً بين متوسطات درجات الطلاب الذكور والاناث علي كل من سمات الثقة بالنفس، وتحمل المسئولية، والاتزان الانفعالي

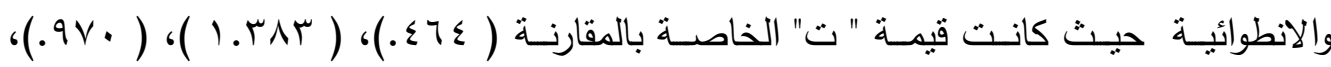

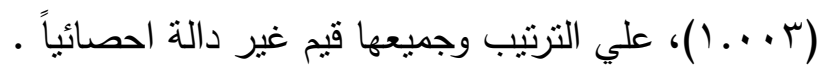

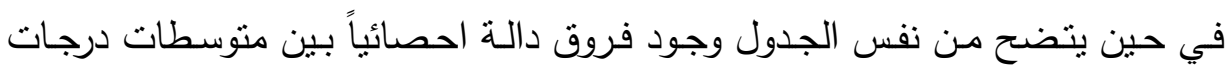

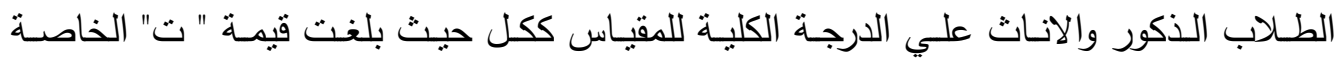

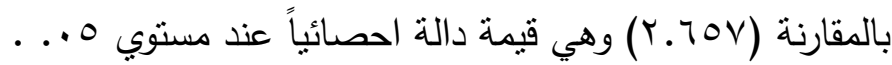

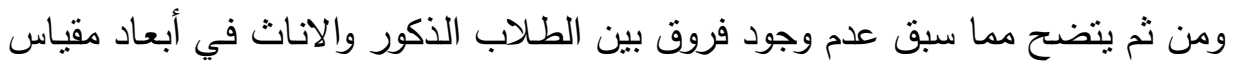

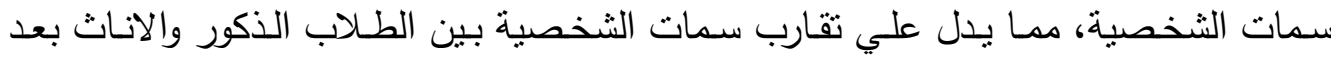

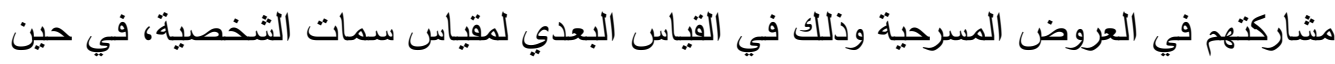

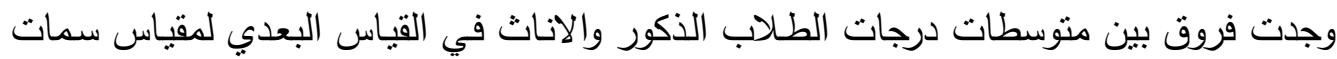

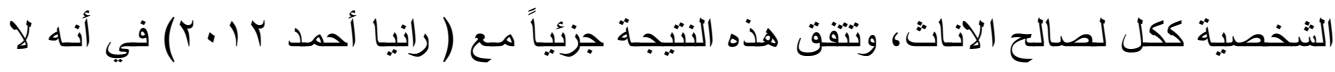

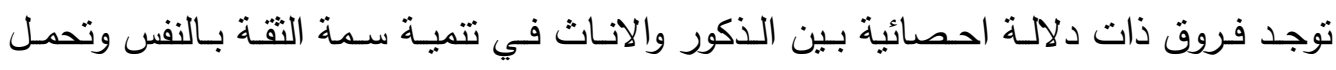
المسئولية . وتدل النتائج السابقة علي تحقق الفرض الثالث بصورة جزئية، وشكل رقم (r) يوضح ذلك. 


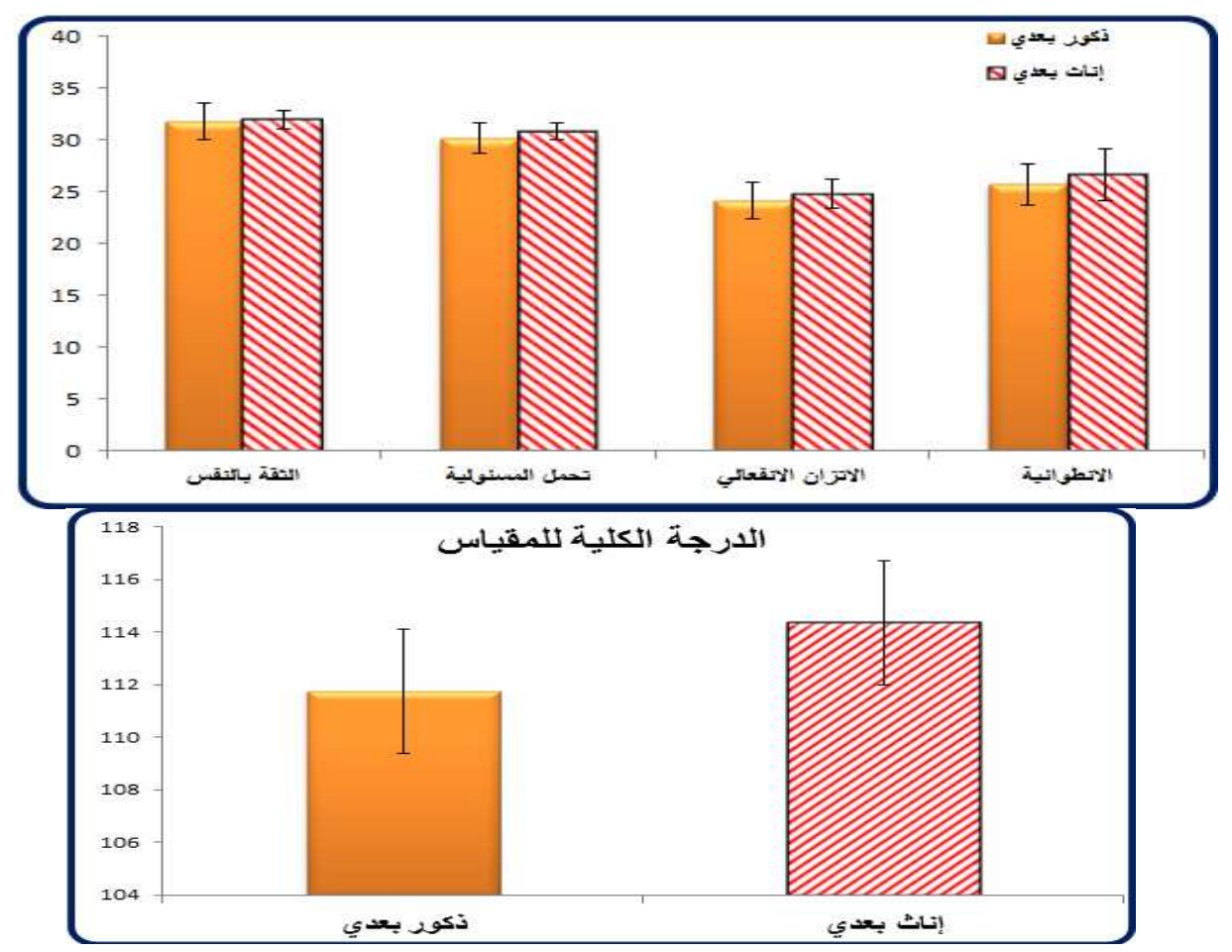

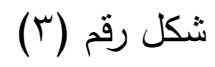

التمثيل البياني لمتوسطات درجات الذكور ومتوسطات درجات الإناث علي مقياس سمات

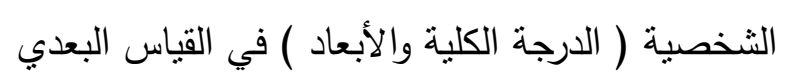

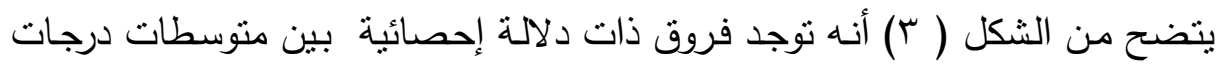

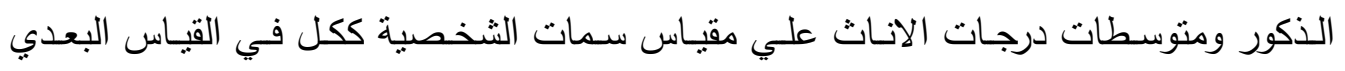
لصالح الإناث.

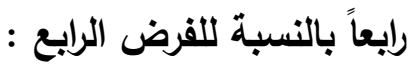

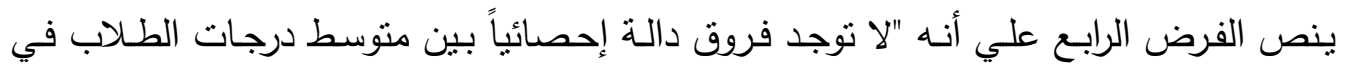
القياس البعدي ومنتسط درجاتهم في القياس التتبعي ( بعد مرور شهر من انتهاء البرنامج ).

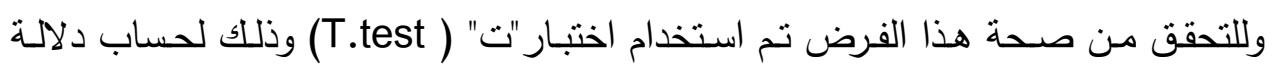
الفروق بين منوسطات درجات الطلاب في القياس البعدي ومتوسطات درجاتهم في القياس التتبعي بعد مرور شهر من تاريخ القياس الثاني ( البعدي ) لمقياس سمات الثخصية.

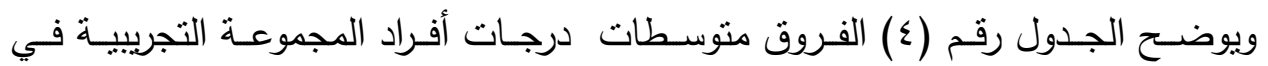
القياسين البعدي والتتبعي علي مقياس سمات الثخصية ( الدرجة الكلية والأبعاد ) . 


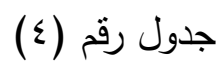

الفرق بين متوسطات درجات الطلاب في القياس البعدي ومنوسطات درجاتهم في القياس

\begin{tabular}{|c|c|c|c|c|c|c|c|c|}
\hline & & & & & & & & \\
\hline \multirow{2}{*}{ الدلالة } & \multirow{2}{*}{ قيمة ت } & \multicolumn{3}{|c|}{ قياس تتبعي } & \multicolumn{3}{|c|}{ قياس بعدي } & \multirow{2}{*}{ سمات الثخصية } \\
\hline & & $\varepsilon$ & s & ن ن & $\varepsilon$ & r & ن & \\
\hline غير دالة & $\ldots \ldots$ & 1.991 & $r 1.9 .9$ & r & 1.194 & $r 1.9 .9$ & $r r$ & الثقة بالنفس \\
\hline غير دالة & $.0 \leqslant 1$ & 1.011 & $r \cdot . V T V$ & rt & $1 . .91$ & $r . .091$ & rr & تحمل المسئولية \\
\hline غير دالة & . ror & 1.74. & TE.TrT & rr & 1.040 & $r \leqslant .0 \leqslant 0$ & rr & الاتزان الانفعالي \\
\hline غير دالة & ו & $1.7 \pi r$ & $r 7.091$ & rr & r...q & גוז.r. & rr & الانطوائية \\
\hline غير دالة & 1.277 & r. $99 \mathrm{~V}$ & $11 \leq .1 \% 4$ & Yr & r.70. & $11 \% .00$ & Yr & اللـقياس \\
\hline
\end{tabular}

يتضح من الجدول السابق (ع) عدم وجود فروق دالة احصائياً بين متوسطات درجات

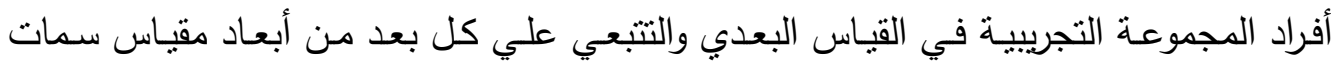
الثخـصية ( الثقة بـالنفس، تحمـل المسئولية، الاتزان الانفعـالي، الانطوائيـة )، وكذللك الدرجـة

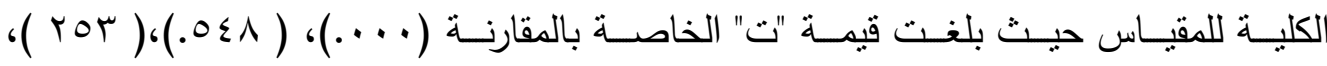

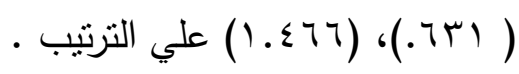

وبملاحظـة منوسطات درجـات أفراد المجموعـة التجريبيـة في القياسين البعدي والتتبعي نجدها متقاربـة إلـي حد ما، وهو ما يدل استمرار التحسن وبقاء الأثر الإيجابي الذي أحدثه

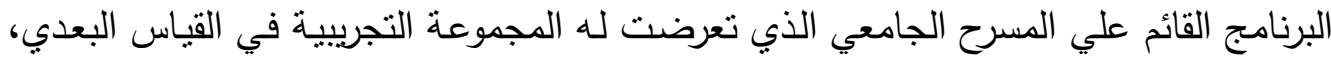

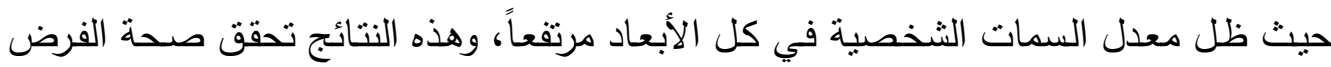
الرابع، ويوضح الثكل رقم ( ع) تلك النتائج • 


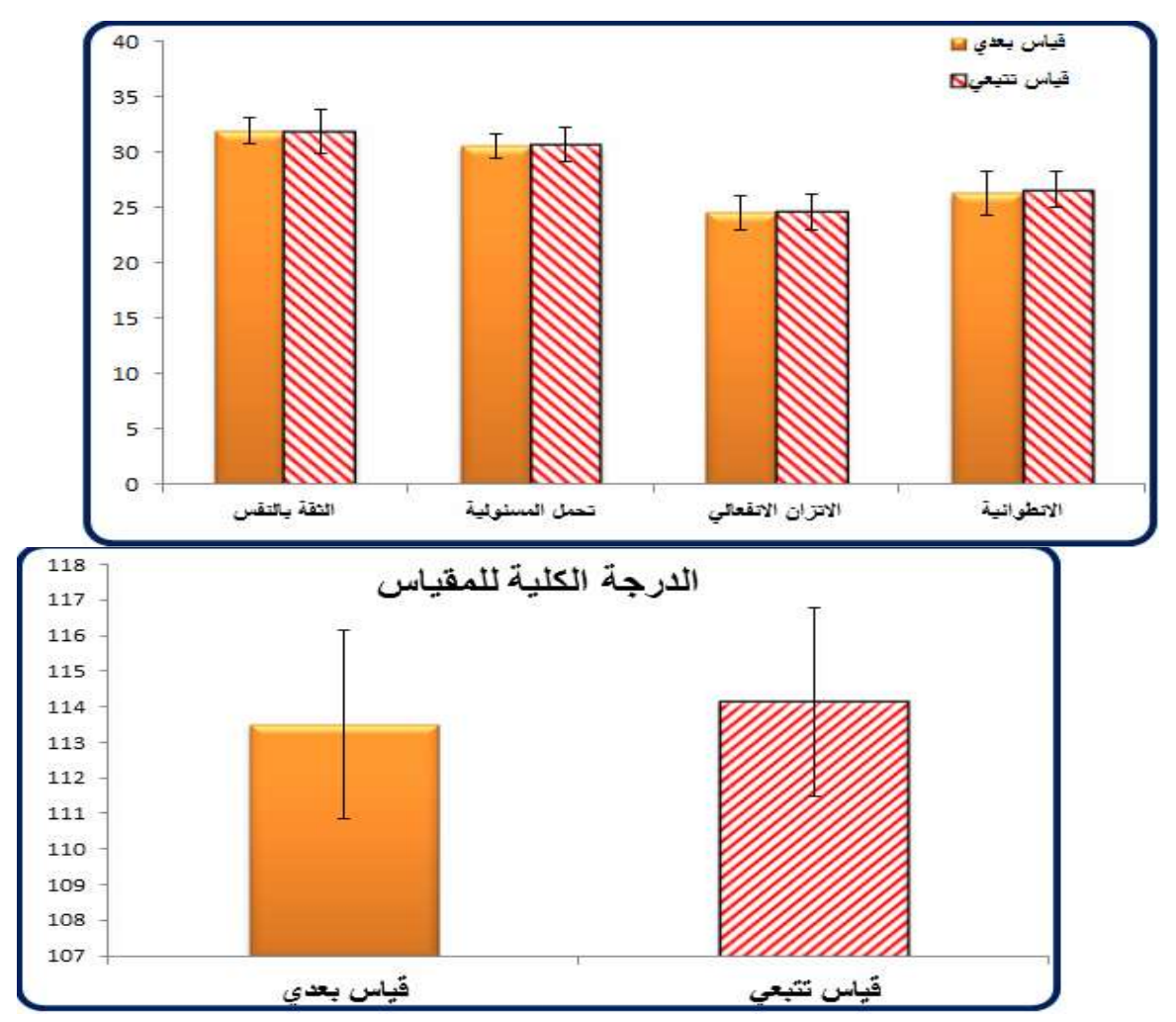

شكل رقم (ع)

التثثيل البياني لمتوسطات درجات الطلاب في القياس البعدي ومتوسطات درجاتهم في

$$
\text { القياس التتبعي }
$$

يتضح من الثكل رقم (ع) أن منوسطات درجات جميع أفراد المجموعة التجريبية علي مقياس سمات الثخصية في القياس البعدي والتتبعي منقاربة بدرجة كبيرة، ولا تعكس إلا فروقاً

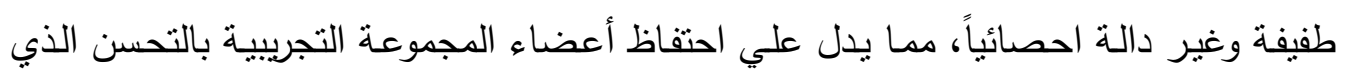
طرأ علي معدل سمات الثخصية في القياس البعدي، وبقاء هذا التحسن في القياس التتبعي. أوضحت النتائج في جدول (ع) عدم وجود فروق جوهرية بين منوسطات درجات أفراد المجموعة التجريبية علي مقياس سمات الثخصية وأبعاده في القياس البعدي، وبين متوسطات

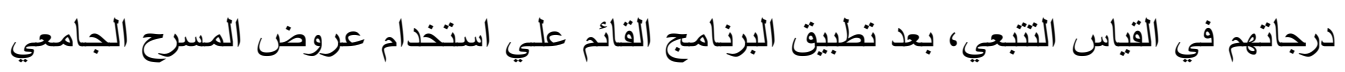

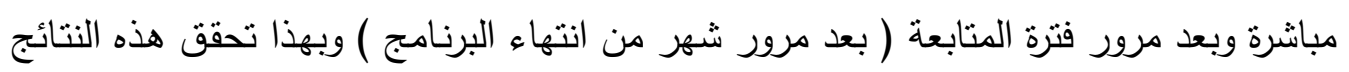

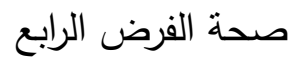


ويمكن تفسير تلك النتائج بأن أفراد المجموعـة التجريبيـة قد حافظوا إلي حد كبير علي المستوي الذي وصلوا إليه في القياس البعدي، حيث اكتسبوا بعض السمات الإيجابية بشكل دال مقارنـة بالقياس القبلي، وقد استمر التحسن في هذه السمات في القياس التتبعي، وبذللك نجد

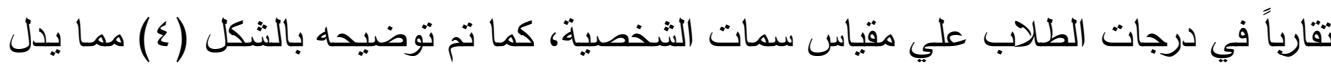
علي استمرار فعالية البرنامج القائم علي استخدام عروض المسرح الجامعي خـلال فترة المتابعة وكفاءته في تقديم عروض من شأنها إتاحة فرص النجاح والإنجاز لدي هؤلاء الطلاب .

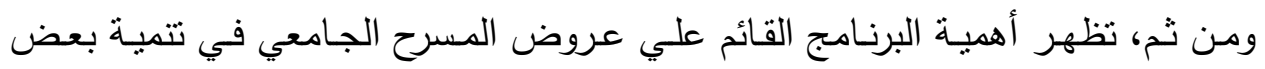

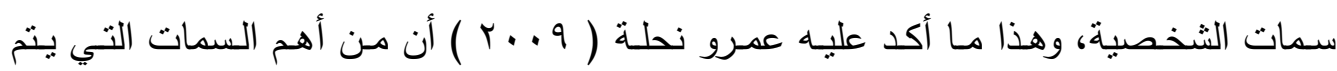

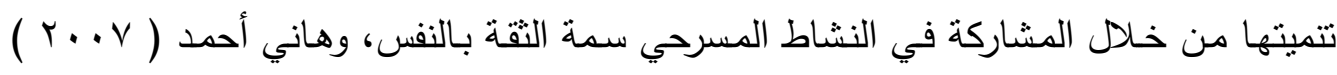
أكد في دراسته أن الطلاب الممارسين للأنشطة الطلابية المختلفة ومنها النشاط المسرحي أكثر

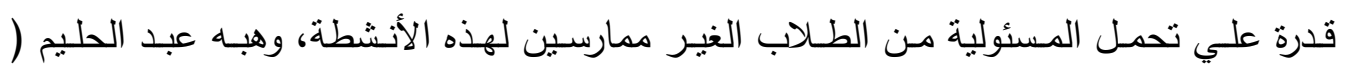

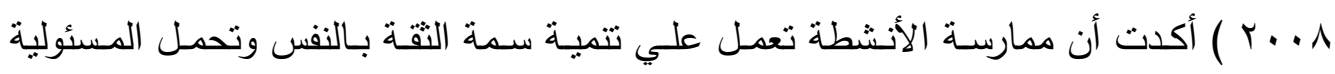
والقضاء علي الخجل والانطوائية .

$$
\text { النتائج التي توصل إليها البحث : :- }
$$

1- وجود فروق دالة احصائياً بين متوسطات درجات الطلاب في القياس القبلي ومتوسطات درجاتهم في القياس البعدي علي مقياس سمات الثخصية لصالح القياس البعدي. r- وجود فروق دالة احصائياً بين متوسطات درجات الذكور ومتوسطات درجات الإناث علي لئي

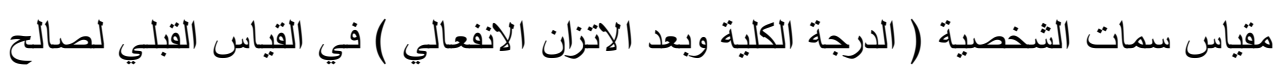
الإناث. r- وجود فروق دالة احصائياً بين متوسطات درجات الذكور ومتوسطات درجات الإناث علي

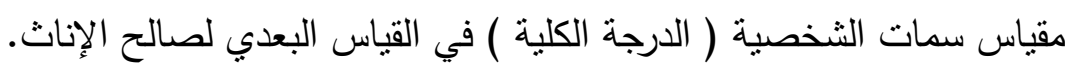

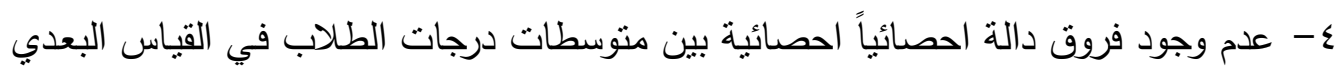
ومتوسطات درجاتهم في القياس التتبعي. 0- من أهم السمات الإيجابية التي اكتسبها الطلاب نتيجة المشاركة في العروض المسرحية الثقة بالنفس وتحمل المسئولية والاتزان الانفعالي. צ- من أهم السمات السلبية التي تخلص منها الطلاب نتيجة المشاركة في العروض المسرحية الأفيات

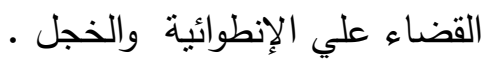


1- الاهتمـام بتفعيل دور المسرح الجـامعي في جميـع الكليـات ليناقش مـن خلالهـ مسشكلات

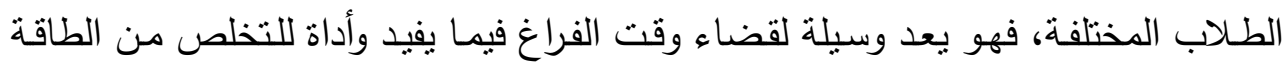

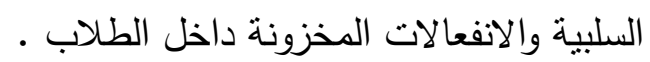

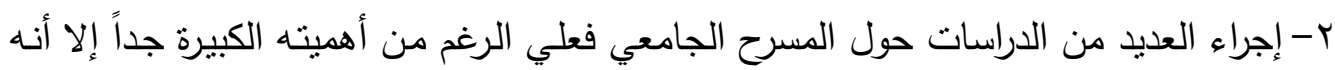

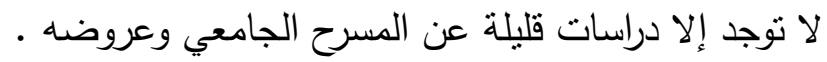

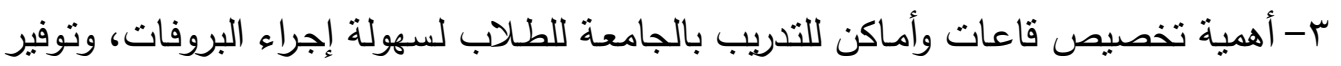

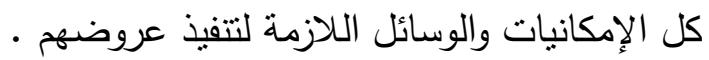
ع-توظيف برامج تقوم علي المسرح الجامعي لتساعد الطلاب علي تلتميـة السمات الإيجابيـة

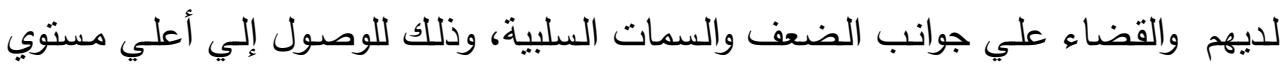

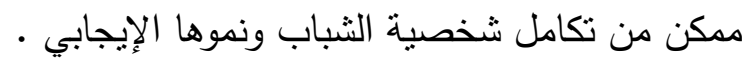

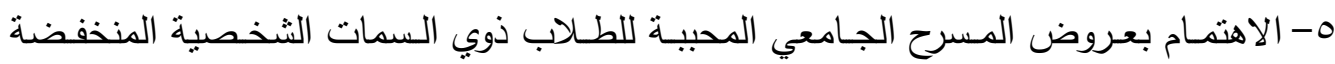

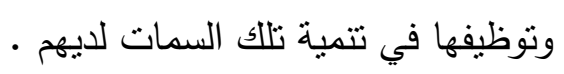
ج- أهميـة إناحسة الفرصـة للطـلاب لتحمـل المسئوليات وممارســة الأدوار المختلفــة في الحيـاة اليومية لتحقيق النمو المتكامل للشخصية في ظل الدرمة الدمب والتشجيع.

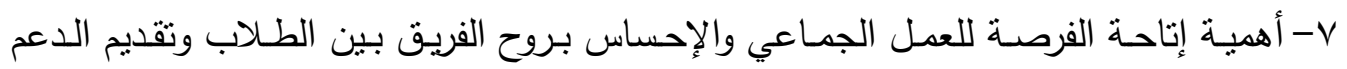

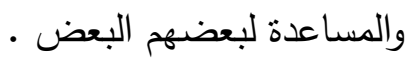
^- استتمار المسرح الجـامعي في التتفيس الانفعـالي وتفريخ الشحنات السلبية أولاً بـأول دون

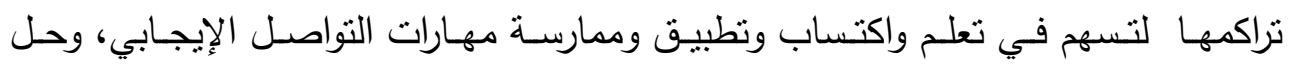

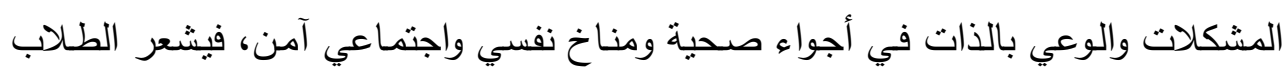

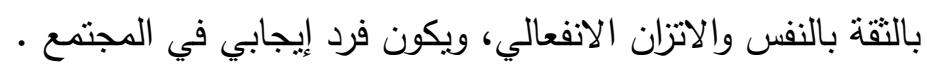

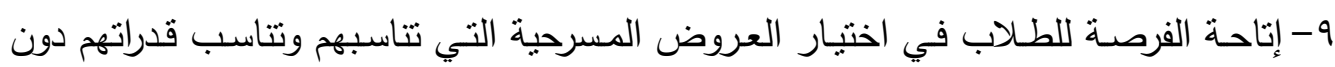

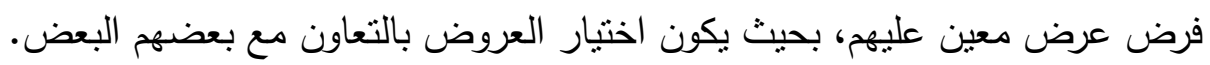

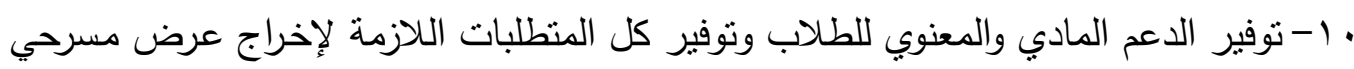




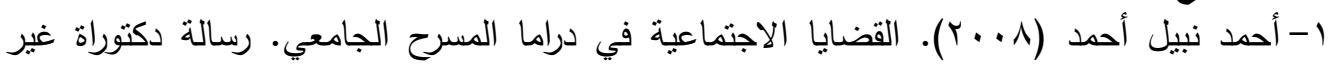

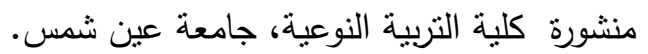

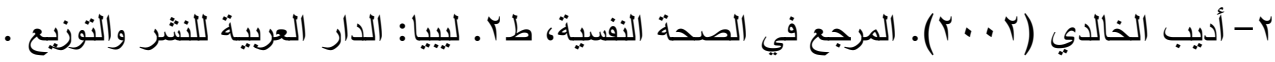

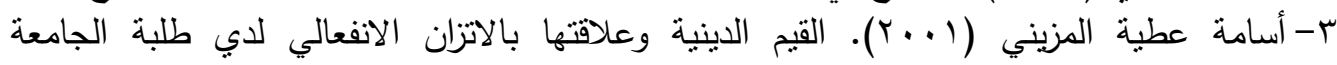

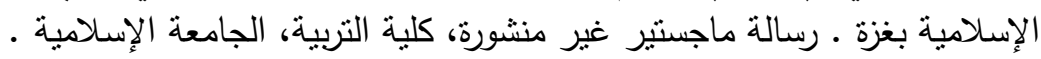

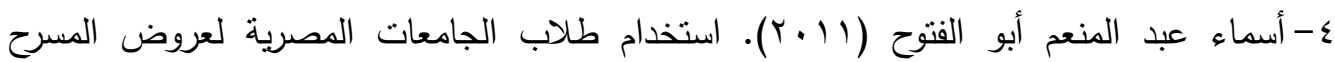

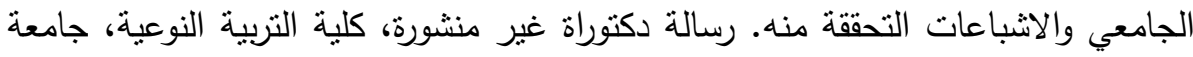

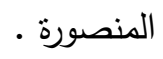

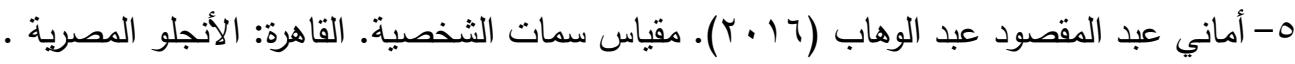

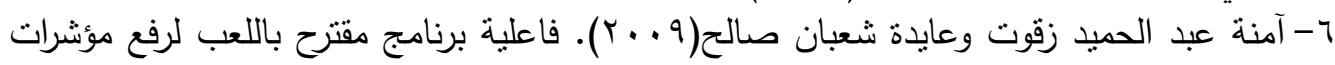

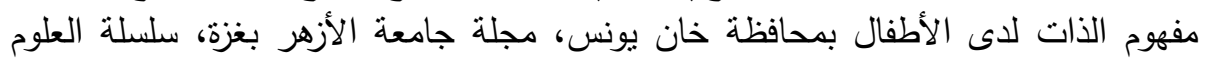

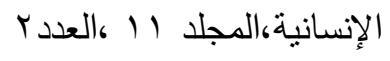

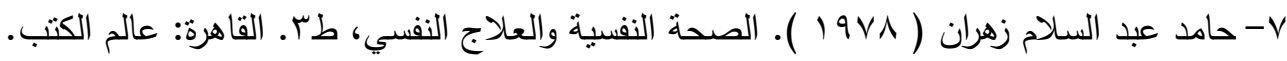

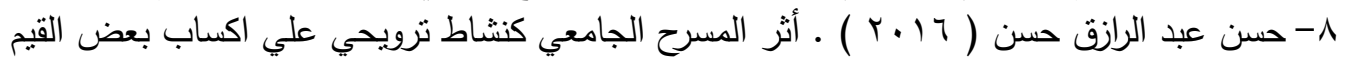

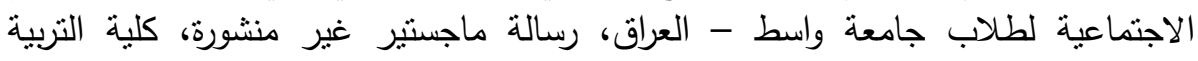

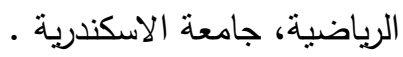
9- حسين محمد أحمد الجبالي (9 ج . ب). أثر استخدام المسرح المدرسي في ترسيخ القيم التربوية. رسالة

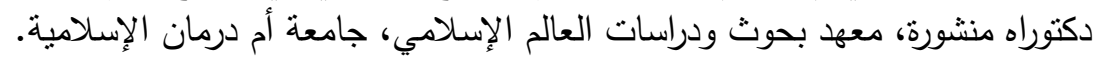
•

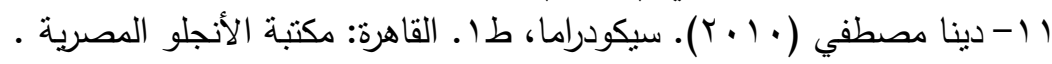

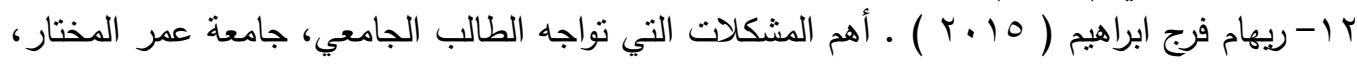
(r)

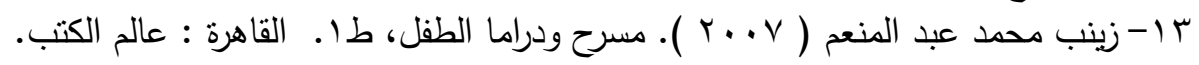

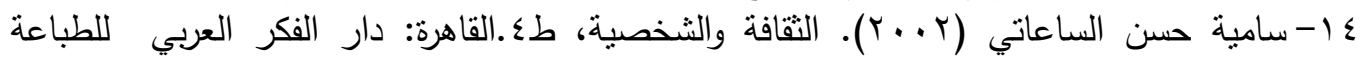
والنشر .

10- السيد سلامة الخميسي (... (Y). الجامعة والسياسة في مصر دراسة نظرية وميدانية عن التربية

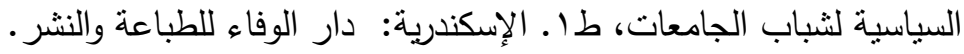

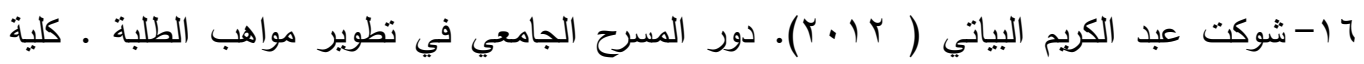

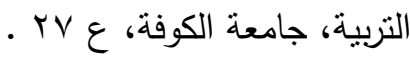

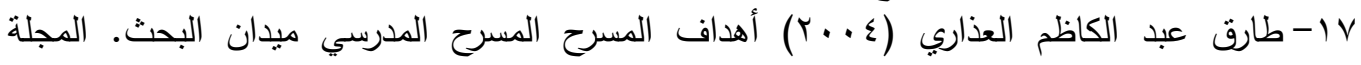

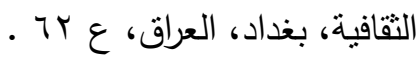

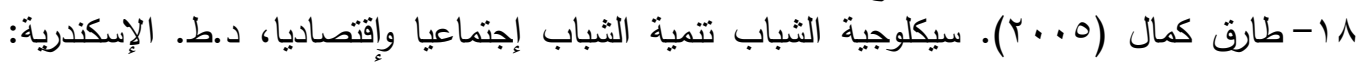
مؤسسة شباب الجامعة. 
9 ا- عبد الحميد عبد الفتاح المغربي (9. . ب). أنماط الثخصية الإدارية وقياسها "كيف تبني وتتمي

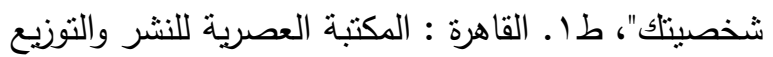

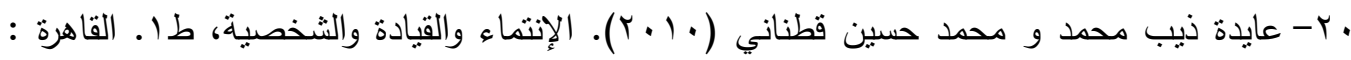

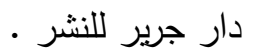

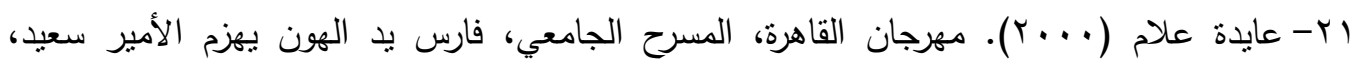

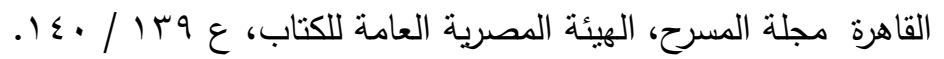

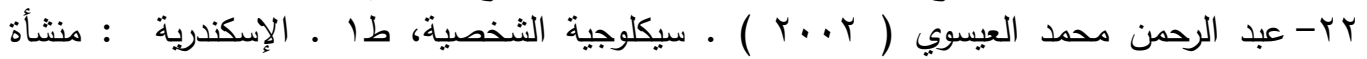

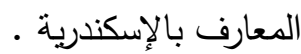

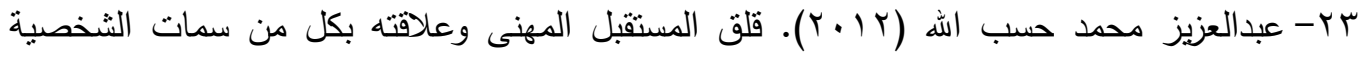

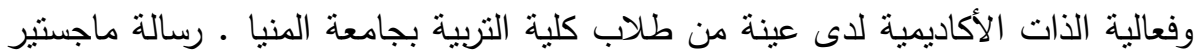
غير منشورة، كلبة النتربية، جامعة المنيا.

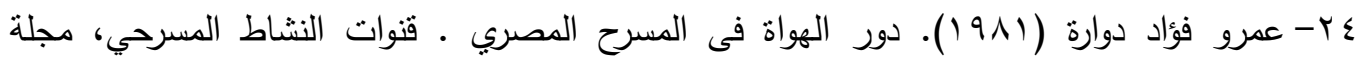

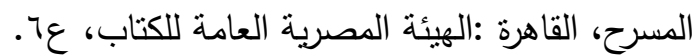

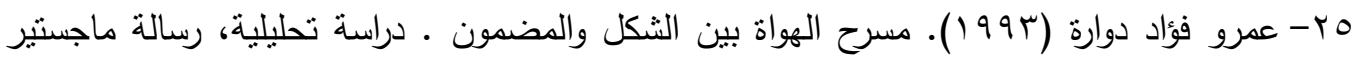

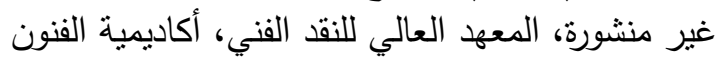

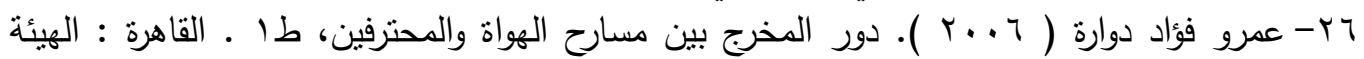

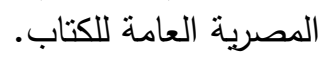

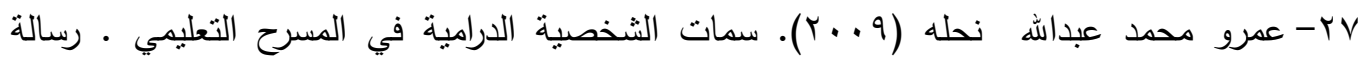

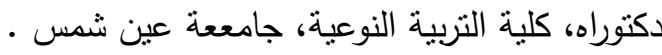

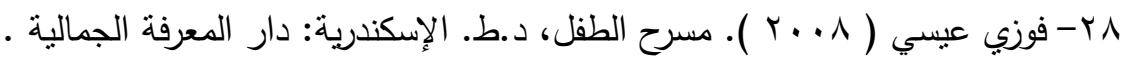

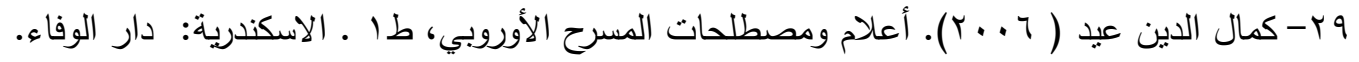

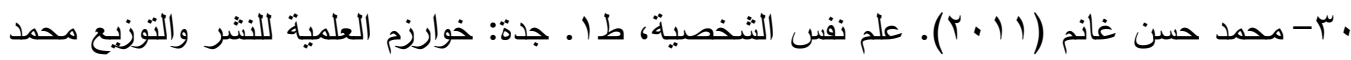

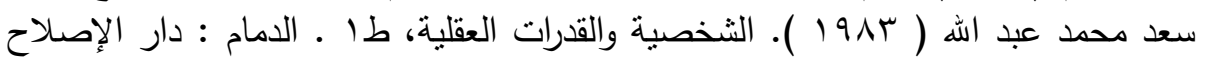

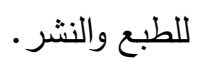

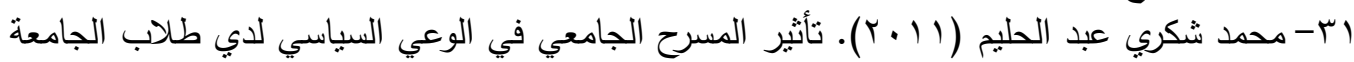

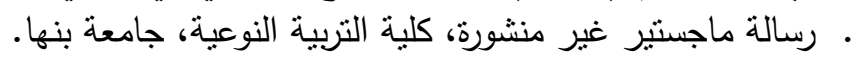

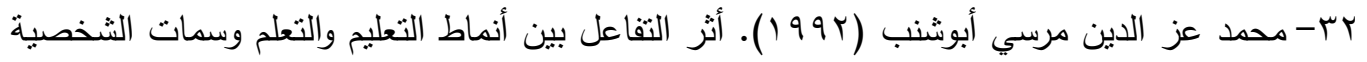

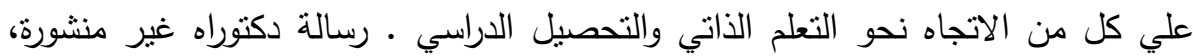

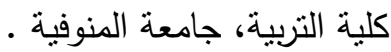

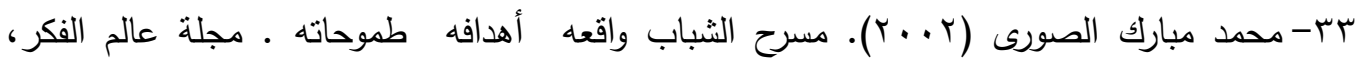

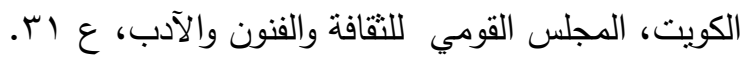

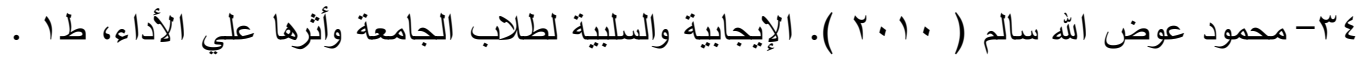

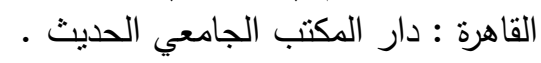

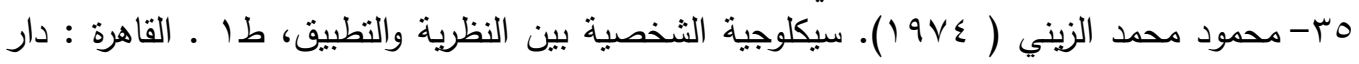

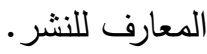




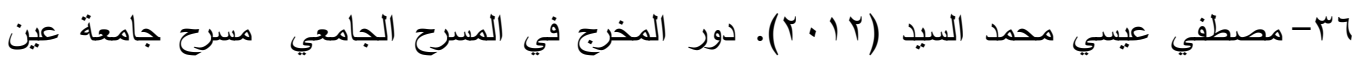

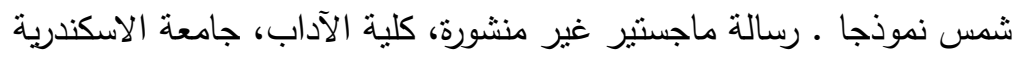

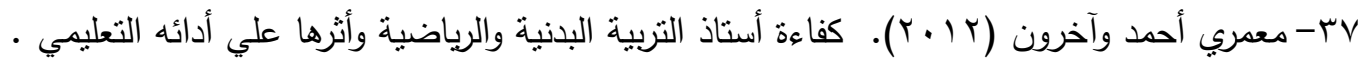
ملخص مذكرة التخرج لنيل درجة الليسانس في تخصص التصان التربية البدنية، كلية العلوم الإنسانية

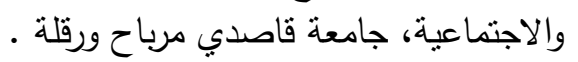

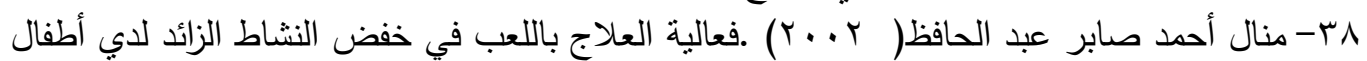

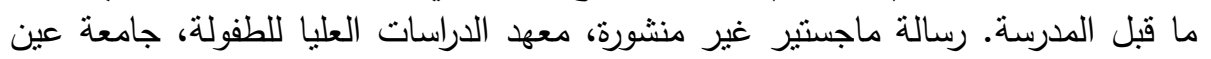

شمس

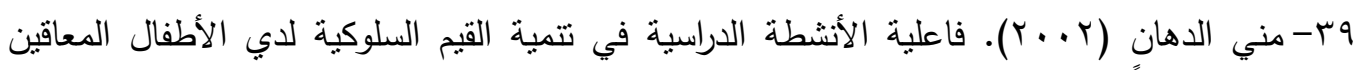

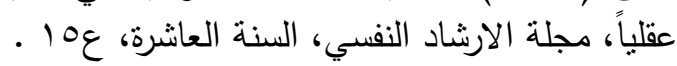

• ع-نبيل سفيان صالح(ع . • ب). المختصر في الثخصية والإرشاد النفسي. القاهرة: إيتراك للنشر والتوزيع.

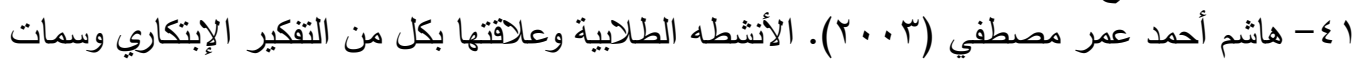
الشخصيه والتحصبل الدراسى لدى طلاب جامعه أسيوط . رسالة دكتوراة غير منشورة، كلية

$$
\text { التربية الرياضية، جامعة أسيوط. }
$$

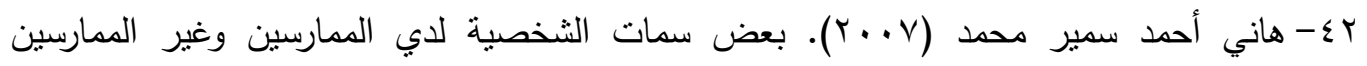
للأنشطة الطلابية من طلاب الجامعة. رسالة ماجستير غير منشورة، معهد الدراسات العليا

للطفولة، جامعة عين شمس.

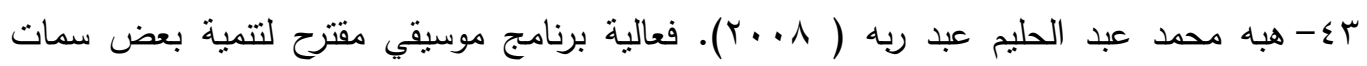

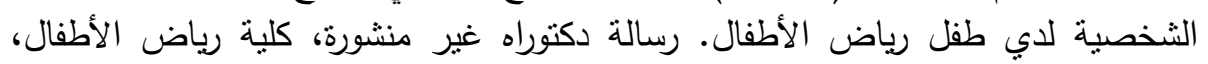

$$
\text { جامعة الإسكندرية. }
$$

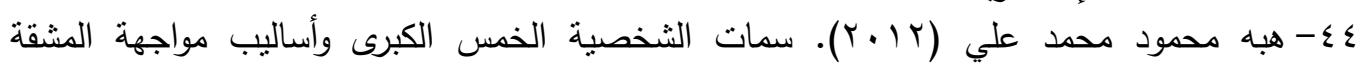
كمنبئات بأعراض الاكثئاب والقلق لاى طلاب ملاب الجامعة . رسالة دكتوراه غير منشورة،كلية

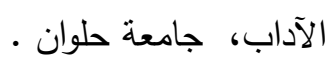

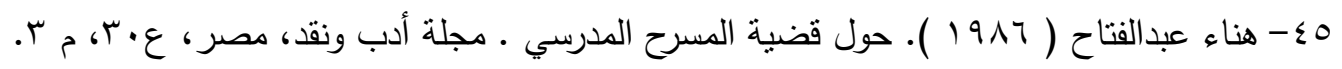

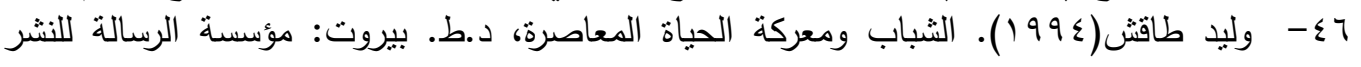

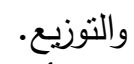

\section{ثانياً: المراجع الأجنبية:}

47-Early,M.A \& Mertler (2002). Deconstructing satistics anxiety, Papper presented at theannual meeting of the Mid- Western educational research association Columbus, October .

48- Roselyn Costantino (1995).University theatre and cultural politics in contemporary Maxican society, PHD, University Altoona of Pennsylvania State, Journal Devoted to the Teaching of Spanish and Portuguese, Vol 78, Nol, 1, Mar. 